\title{
Buku Ajar Mata Kuliah "Elaborasi Pendidikan Islam: Konsep dan Kajian Islam
}

\author{
Oleh \\ Ainun Nadlif
}

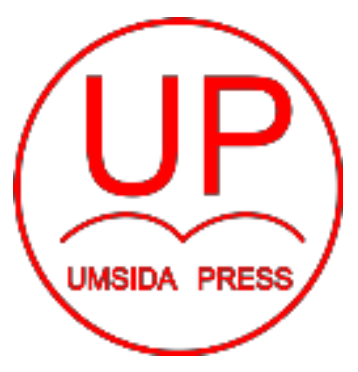

Diterbitkan oleh

UMSIDA PRESS

J1. Mojopahit 666B Sidoarjo

ISBN: 978-623-7578-15-4

Copyright $^{\oplus} 2019$.

Authors

All rights reserved 
Buku Ajar

"Elaborasi Pendidikan Islam: Konsep dan Kajian Islam

Penulis :

Ainun Nadlif.

ISBN :

978-623-7578-15-4

\section{Editor :}

Septi Budi Sartika, M.Pd

M. Tanzil Multazam, S.H., M.Kn.

Copy Editor :

Fika Megawati, S.Pd., M.Pd.

Design Sampul dan Tata Letak :

Mochamad Nashrullah, S.Pd

\section{Penerbit :}

UMSIDA Press

\section{Redaksi :}

Universitas Muhammadiyah Sidoarjo

J1. Mojopahit No 666B

Sidoarjo, Jawa Timur

\section{Cetakan pertama, Agustus 2019}

(C) Hak cipta dilindungi undang-undang

Dilarang memperbanyak karya tulis ini dengan suatu apapun tanpa ijin tertulis dari penerbit. 


\section{Kata Pengantar}

Puji syukur kehadirat Allah swt., Tuhan Yang Maha Esa hanya kepada-Nya kita berserah diri dan mencari ridlaNya. Semoga kita selalu memperoleh petunjuk dan bimbinganNya kejalan yang benar dan mampu meraih kebahagiaan hidup di dunia dan akherat. Shalawat serta salam tetap tercurahkan kepada Nabi Muhammad saw hamba Allah swt terbaik, keluarga, sahabat, dan para pengikutnya yang selalu tunduk kepada ajaran yang disampaikannya.

Memasuki awal abad XXI, pendidikan Islam sangat dibutuhkan oleh Ummat. Pendidikan Islam yang diharapkan dalam hal ini adalah pendidikan yang mampu menguatkan nilai-nilai ajaran Islam dalam kehidupan masyarakat. Pendidikan Islam yang mampu mencegah keruntuhan akhlak dan perilaku generasi Bangsa dan Ummat, karena intelektual berkembang dengan cepat, teknologi semakin pregressive, sementara kehidupan beragama dan keyakinan terhadap agama semakin terkikis.

Buku yang ada dihadapan pembaca ini berjudul "Elaborasi Pendidikan Islam: Konsep dan Kajian Islam" disusun sebagai bahan introspeksi akan pentingnya eksistensi pendidikan Islam. Konsep Pendidikan dan realita pendidikan adalah dua aspek yang saling berkaitan, karena pendidikan Islam selalu memotret persoalan manusia dari tiga aspek utama pendidikan yaitu, manusia butuh belajar, manusia harus dibimbing, dan manusia harus dilatih. Dalam konteks tersebut, Pendidikan Islam harus disajikan tanpa batas dan tanpa mengenal waktu dan perubahan, karena ia akan dibutuhkan oleh setiap perubahan zaman. Buku "Elaborasi Pendidikan Islam" sangat penting dibaca oleh Mahasiswa Fakultas Agama Islam, Guru-guru Agama Islam baik yang berada di lembaga pendidikan umum maupun Guru-guru dilembaga pendidikan bercirikan Islam sebagai referensi/rujukan kajian pendidikan Islam saat ini.

Semoga buku ini bermanfaat bagi para pembaca yang budiman, dalam memperteguh dan meningkatkan motivasi beragama dengan baik dan konsekuen. Dengan segala perhatian dan kepedulian pembaca, kritik dan saran pada buku kami harapkan untuk kiranya menjadi bahan evaluasi selanjutnya. Mudah-mudahan Allah swt Tuhan Yang Maha Esa melimpahkan keberkahan kepada kita semua Amin... 
BAB I

KEDUDUKAN DAN TUGAS MANUSIA DI BUMI

\section{Capaian Perkuliahan}

1. Mampu memahami manusia sebagai ciptaan Allah swt dan mengerti proses penciptaan manusia

2. Mampu mendeskripsikan tentang eksistensi manusia sebagai hamba Allah swt dan fungsinya sebagai hamba Allah swt

3. Mampu memahami makna manusia sebagai khalifah di bumi dan mampu menganalisis peran-peran kekhalifahan

4. Mampu mengimplementasikan tugas-tugas manusia sebagai Khalifah dan membuktikan perannya sebagai khalifah (pemimpin) di muka bumi

\section{A. Hakekat Manusia}

Manusia ditinjau dari segi bahasa adalah ma.nu.si.a yang berarti nama makhluk yang berakal budi (mampu menguasai makhluk yang lain). Me.ma.nu.si.a.kan artinya menganggap, memperlakukan sebagai manusia. Pe.ma.nu.si.a.an artinya proses menjadikan manusia agar memiliki rasa kemanusiaan. ${ }^{1}$ Dalam Al-Qur'an banyak ditemukan gambaran yang membicarakan tentang manusia dan makna filosofis dari penciptaannya. Manusia sebagai makhluk-Nya paling sempurna dan sebaik-baik ciptaan yang dilengkapi dengan akal pikiran. Dalam hal ini Ibn 'Arabi misalnya menggambarkan hakikat manusia dengan mengatakan bahwa tak ada makhluk Allah swt yang lebih sempurna kecuali manusia. manusia memiliki daya hidup, mengetahui, berkehendak, berbicara, melihat, mendengar, berfikir, dan memutuskan. Manusia adalah makhluk yang tinggal di bumi "kosmis" yang sangat penting, karena dilengkapi dengan semua pembawaan atau fitrah dan syarat-syarat yang diperlukan baginya untuk mengemban tugas dan fungsinya sebagai makhluk Allah swt di muka bumi. ${ }^{2}$

\footnotetext{
${ }^{1}$ Departemen Pendidikan dan Kebudayaan, Kamus Besar Bahasa Indonesia, Edisi dua, Jakarta: Balai Pustaka, 1991. HIm.629

2 Ismail Raji’ Al-Faruqi, Islam dan Kebudayaan, (Bandung: Mizan, 1984), 37.
} 
Gambar1.1

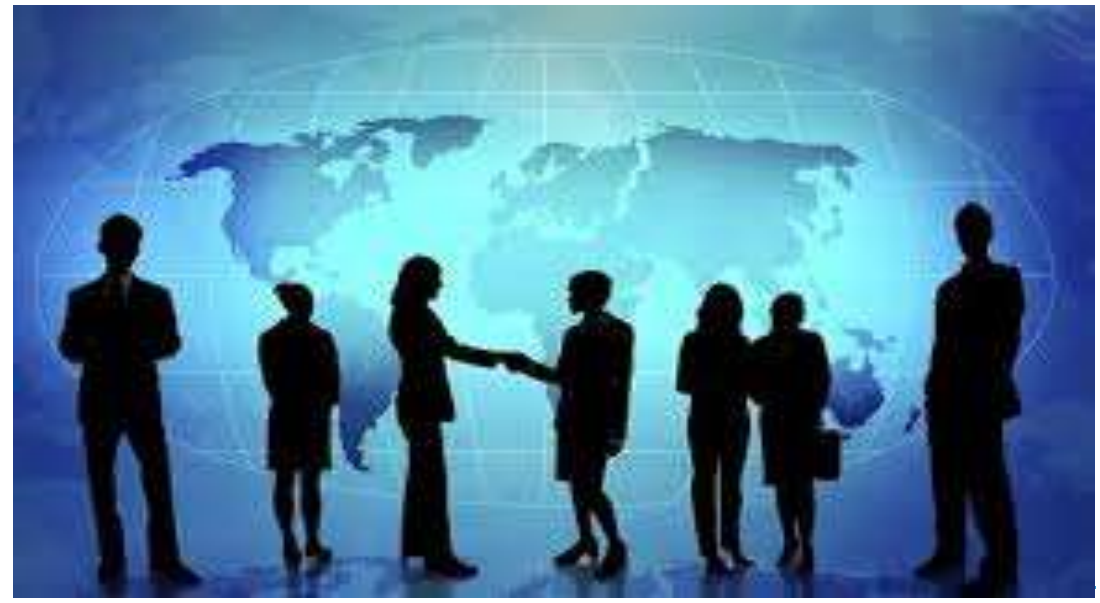

Bagaimana bentuk dan pola peran setiap manusia, secara garis besar dapat dilihat dari kedudukan yang disandangnya. Untuk mengetahui hal itu, perlu dirujuk kepada penamaan yang disandangnya. Demikian pula akan halnya mengenai peran manusia. Peran manusia ini dapat dirujuk antara lain dari berbagai sebutan yang diberikan kepada manusia. Selaku makhluk ciptaan Allah swt manusia dianugerahi penciptaNya dengan sejumlah nama atau sebutan yang melekat pada keberadaannya sebagai ciptaan.

Dalam al-Qur'an manusia disebut dengan berbagai nama antara lain: al-Basyr, al-Nas, Bani Adam, al-Ins, Abd Allah dan khalifatullah. Nama-nama sebutan ini mengacu pada gambaran tugas yang seharusnya diperankan oleh manusia sebagai penghuni bumi. Sehubungan hal itu maka untuk memahami peran manusia, perlu dipahami konsep yang mengacu kepada sebutan dimaksud karena pemahaman tentang peran manusia erat kaitannya dengan sebutan yang disandangnya. ${ }^{3}$

\section{Konsep al-Basyr}

Manusia dalam konteks al-Basyr, dipandang dari pendekatan biologis. Sebagai makhluk biologis berarti manusia terdiri atas unsur materi, sehingga menampilkan sosok dalam bentuk fisik material, berupa tubuh kasar (ragawi). Dalam kaitan ini manusia merupakan makhuk jasmaniah yang secara umum terikat kepada kaidah-kaidah umum dari kehidupan makhluk biologis.

Al-Basyar adalah gambaran manusia secara materi, yang dapat dilihat, memakan sesuatu, berjalan, dan berusaha untuk memenuhi kebutuhan kehidupannya. Manusia dalam pengertian ini terdapat dalam al-Qur'an sebanyak 35 kali diberbagai surah. Dari pengertian-

\footnotetext{
${ }^{3}$ Jalaluddin, Teologi Pendidikan, (Jakarta: Raja Grafindo Persada, 2003), 19.
} 
pengertian tersebut, 25 kali diantaranya berbicara tentang "kemanusiaan" para rasul dan nabi, 13 kali diantaranya menggambarkan polemik para rasul dan nabi dengan orang-orang kafir yang isinya keengganan orang-orang kafir terhadap apa yang dibawa para rasul dan nabi karena menurut mereka rasul itu adalah manusia seperti mereka juga, dan sejumlah ayat yang mengandung bahwa memang para rasul itu adalah manusia yang sama seperti manusiamanusia yang lainnya. ${ }^{4}$

Pengakuan rasul (Muhammad saw) bahwa dia juga manusia dapat dilihat dalam surah al-Kahfi ayat 110. Allah swt berfirman

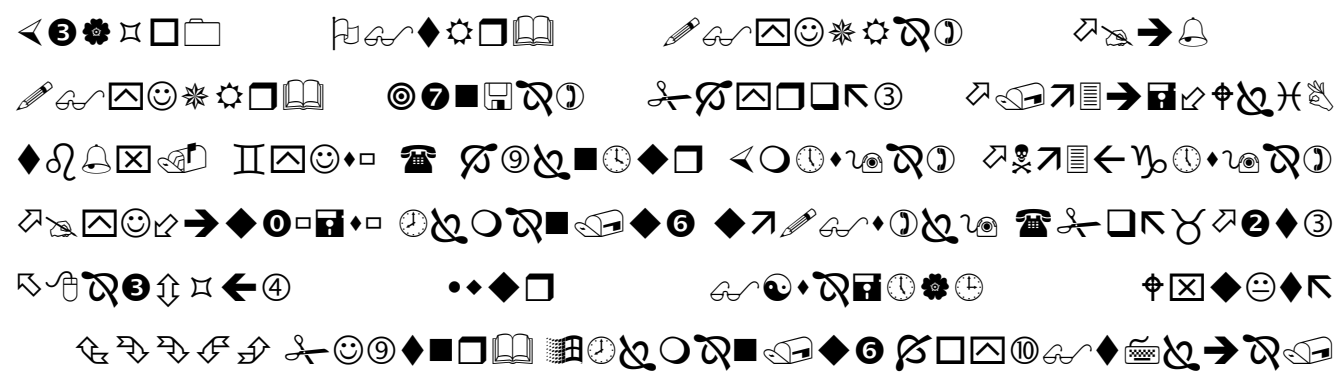

Artinya: Katakanlah: Sesungguhnya aku ini manusia biasa seperti kamu, yang diwahyukan kepadaku: "Bahwa Sesungguhnya Tuhan kamu itu adalah Tuhan yang Esa". Barangsiapa mengharap perjumpaan dengan Tuhannya, Maka hendaklah ia mengerjakan amal yang saleh dan janganlah ia mempersekutukan seorangpun dalam beribadat kepada Tuhannya".

Berdasarkan konsep al-Basyr, manusia tidak jauh berbeda dengan makhluk biologis lainnya. Dengan demikian kehidupan manusia itu terikat kepada kaidah dan prinsip-prinsip kehidupan biologis. seperti berkembang biak, mengalami fase pertumbuhan dan perkembangan, serta fase dalam mencapai tingkat kematangan dan kedewasaan. Manusia memerlukan makanan dan minuman untuk hidup, dan juga memerlukan pasangan hidup untuk proses pelanjut keturunannya. Lengkapnya manusia memiliki dorongan biologis seperti dorongan makan dan minum, dorongan seksual, dorongan pertahankan diri, dan dorongan mengembangkan diri, sebagai bentuk dorongan primer biologis. ${ }^{5}$

Penjelasan al-Quran tentang proses dan fase perkembangan manusia sebagai makhluk biologis adalah sebagai berikut:

a. Prenatal (sebelum lahir), proses penciptaan manusia berawal dari pembuahan (pertemuan ovum dengan sperma) di dalam rahim, pembentukan fisik janin (Qs. alMu'minun:12-14).

\footnotetext{
${ }^{4}$ Dewan Redaksi Ensyklopedi Islam, Ensiklopedia Islam, Jakarta: Ichtiyar Baru Van Hoeve, 1999. HIm161

${ }^{5}$ Ibid, hlm.19-20.
} 


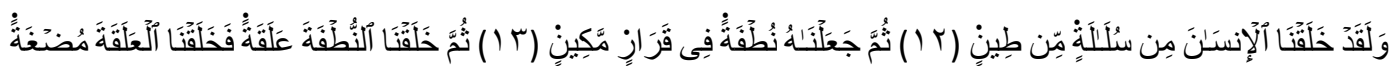

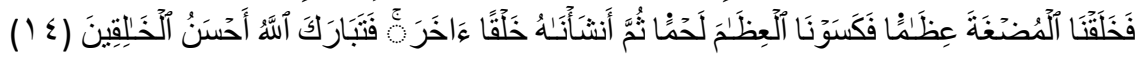
Artinya: "Dan sesungguhnya Kami telah menciptakan manusia dari suatu saripati tanah. Kemudian Kami jadikan saripati itu air mani [yang disimpan] dalam tempat yang kokoh [rahim]. Kemudian air mani itu Kami jadikan segumpal darah, lalu segumpal darah itu Kami jadikan segumpal daging, dan segumpal daging itu Kami jadikan tulang belulang, lalu tulang belulang itu Kami bungkus dengan daging. Kemudian Kami jadikan dia makhluk yang [berbentuk] lain. Maka Maha Sucilah Allah, Pencipta Yang Paling Baik.

Gambar 1.2

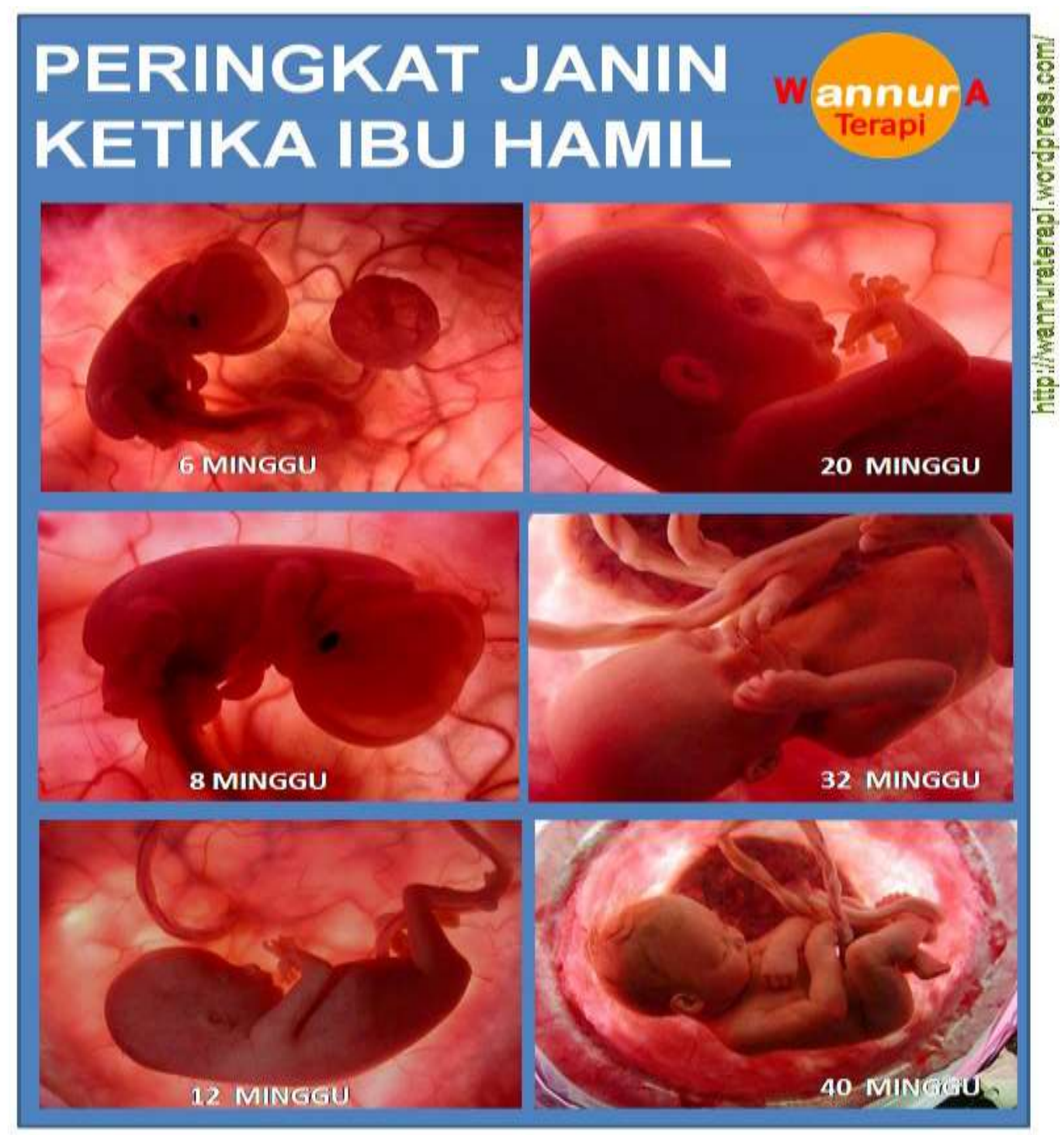

b. Postnatal (sesudah lahir) proses perkembangan dari bayi, remaja, dewasa, hingga usia lanjut (QS.40:67).

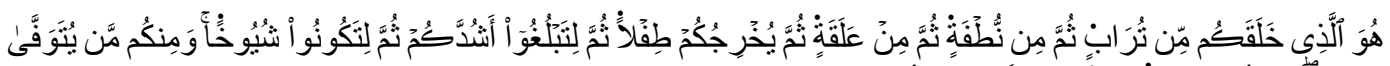

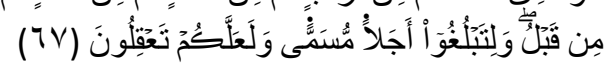


Artinya :"Dia-lah yang menciptakan kamu dari tanah kemudian dari setetes air mani, sesudah itu dari segumpal darah, kemudian dilahirkannya kamu sebagai seorang anak, kemudian [kamu dibiarkan hidup] supaya kamu sampai kepada masa [dewasa], kemudian [dibiarkan kamu hidup lagi] sampai tua, di antara kamu ada yang diwafatkan sebelum itu. [Kami perbuat demikian] supaya kamu sampai kepada ajal yang ditentukan dan supaya kamu memahami [nya]. (67)"

Gambar 1.3

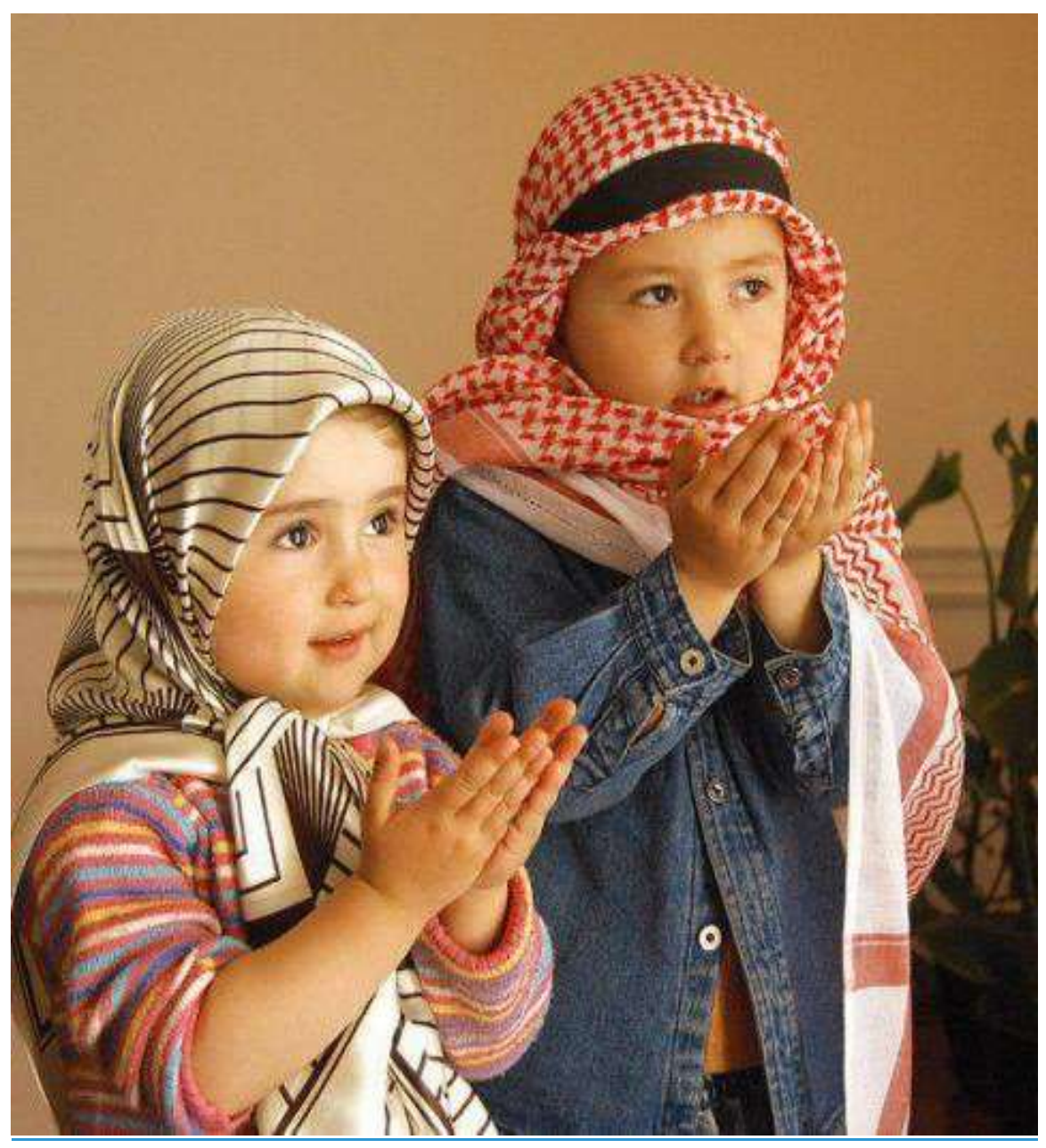




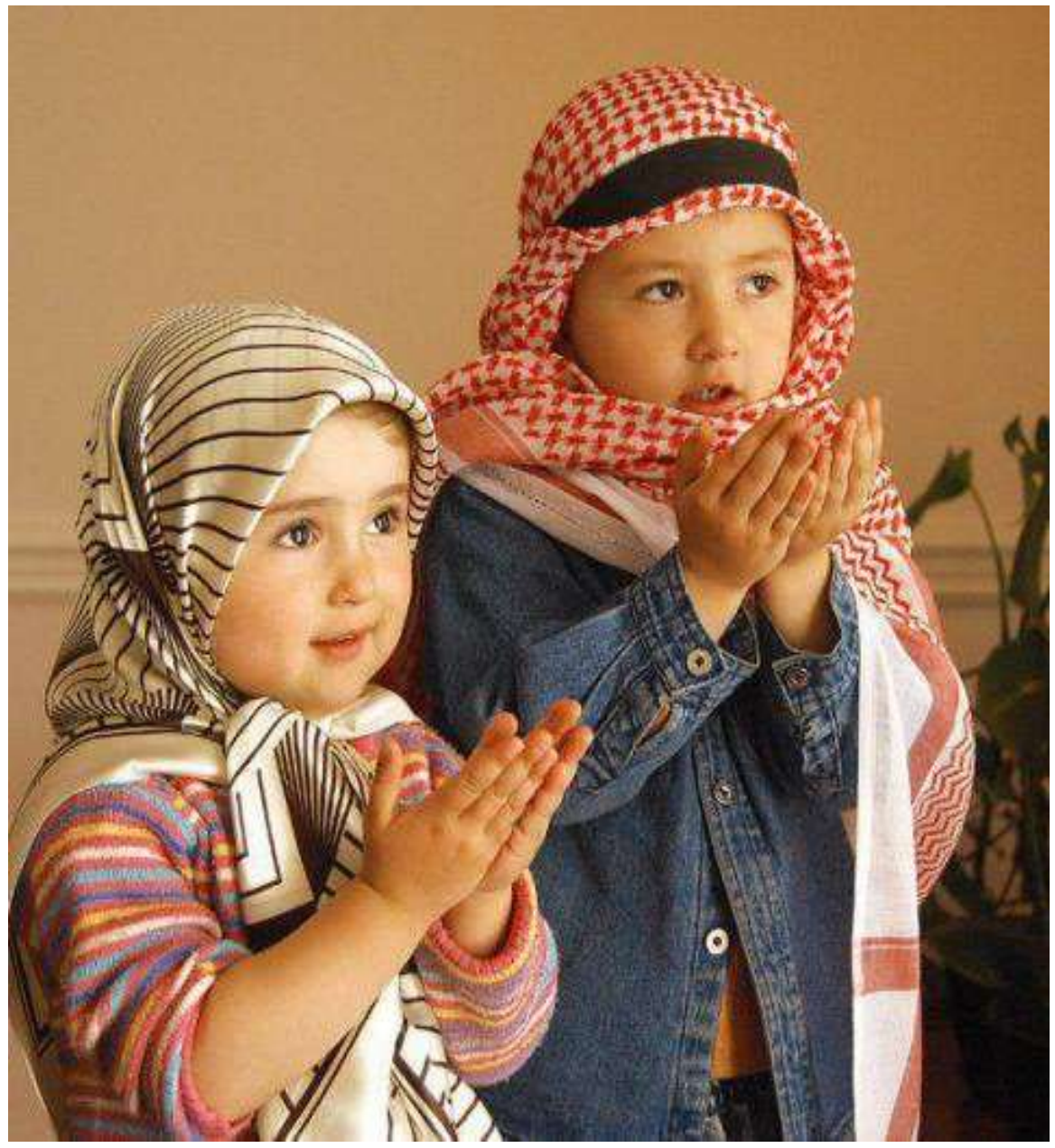

Sebagai makhluk biologis, manusia pun mengalami proses akhirnya secara fisik yaitu mati. Mati merupakan tahap akhir dari proses pertumbuhan dan perkembangan manusia sebagai makhluk biologis.

Selama masa kehidupan sebagai makhluk biologis, manusia dalam perkembangannya memerlukan makan dan minum. Setelah dewasa manusia memerlukan pasangan hidup untuk menyalurkan dorongan seksualnya. Sebagai makhluk ciptaan, pemenuhan kebutuhan itu telah diatur oleh penciptaNya. Tujuan utama ketentuan dan aturan dari sang pencipta itu adalah agar manusia dapat menjalankan peran dalam hidupnya secara benar, sesuai dengan hakikat penciptaannya. Melalui peran tersebut, diharapkan manusia akan selalu berada dalam kondisi kehidupan yang selamat. ${ }^{6}$

Gambar 1.4

\footnotetext{
${ }^{6}$ Jalaluddin, Teologi Pendidikan, (Jakarta: PT Raja Grafindo Persada, 2003), 20.
} 


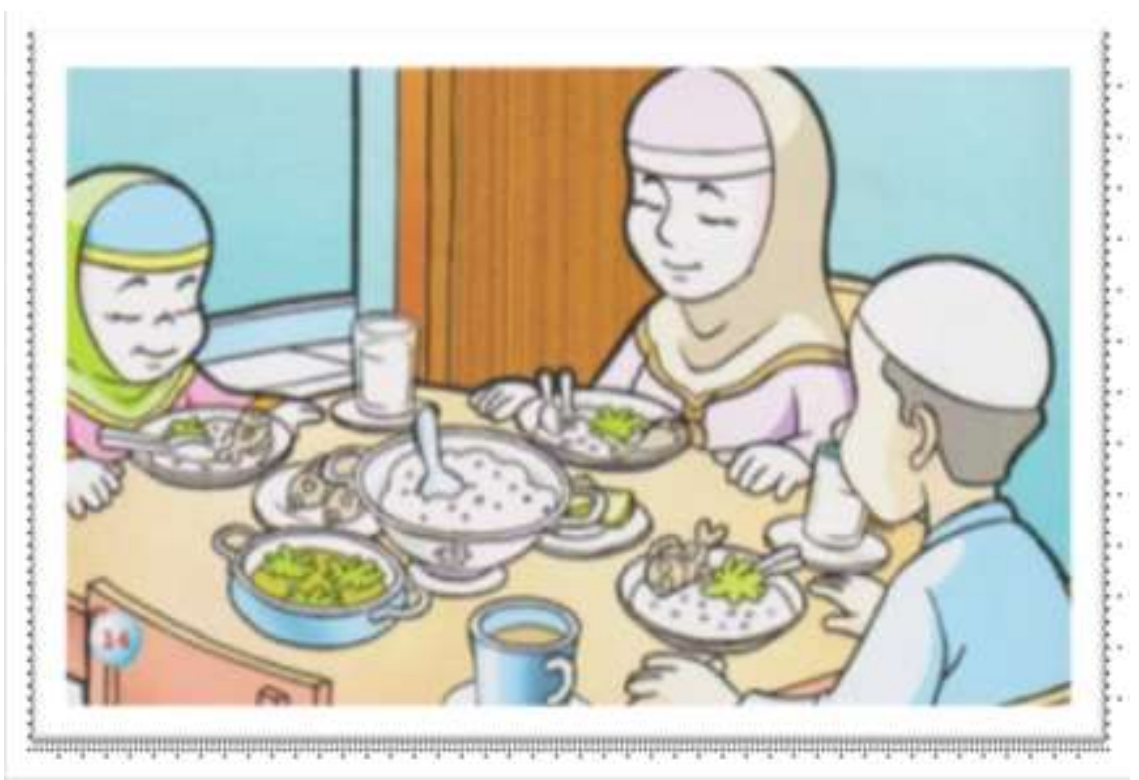

Dalam kaitannya dengan kebutuhan primer ini pula, al-Quran mengatur peran manusia selaku makhluk biologis ciptaan Allah swt. Dengan demikian pertumbuhan dan perkembangan serta dorongan biologisnya akan berjalan secara harmonis dan terarah. Untuk kebutuhan makan dan minum, dibuat tata aturan agar manusia dapat memenuhi kriteria halal (absah) dan baik (bergizi) agar sesuai dengan kebutuhannya Allah swt menjelaskan dalam alQur'an surat al-Nahl: 65-69

$\checkmark$ Air dijelaskan dalam QS. Al-Nahl ayat: 65

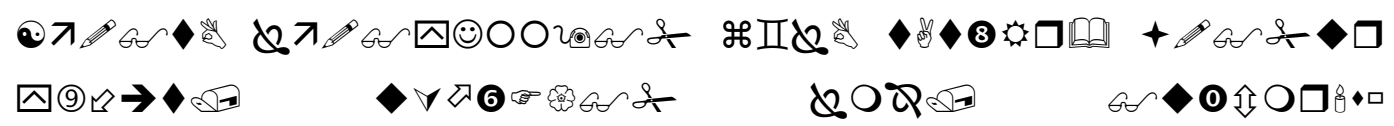

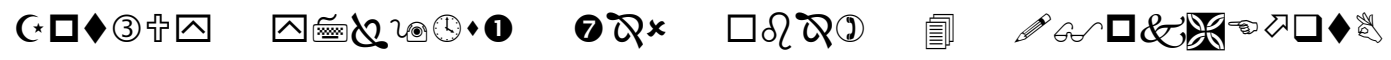

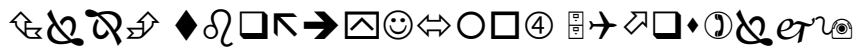
Artinya : Dan Allah menurunkan dari langit air (hujan) dan dengan air itu dihidupkan-Nya bumi sesudah matinya. Sesungguhnya pada yang demikian itu benar-benar terdapat tanda-tanda (kebesaran Tuhan) bagi orang-orang yang mendengarkan (pelajaran).

$\checkmark$ Susu dijelaskan dalam al-Qur'an surat al-Nahl ayat: 66

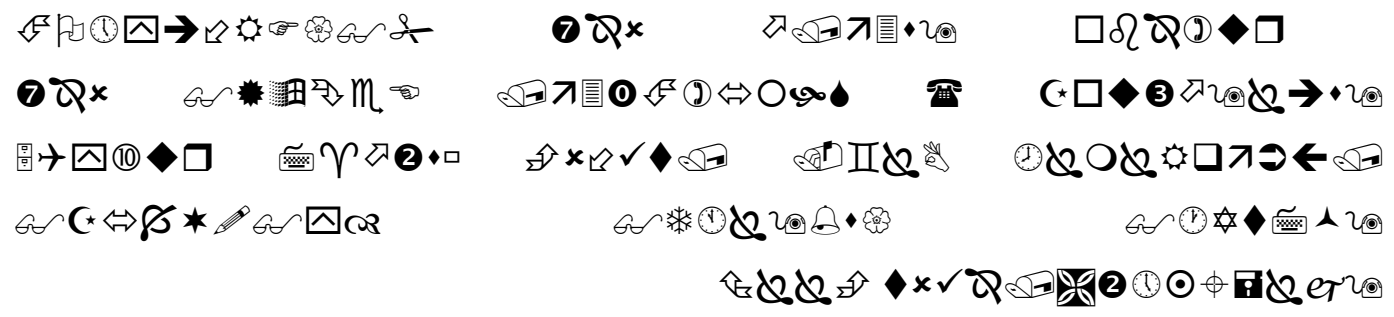
Artinya: dan Sesungguhnya pada binatang ternak itu benar-benar terdapat pelajaran bagi kamu. Kami memberimu minum dari pada apa yang berada dalam perutnya (berupa) susu 
yang bersih antara tahi dan darah, yang mudah ditelan bagi orang-orang yang meminumnya.

$\checkmark$ Buah-buahan dijelaskan dalam al-Qur'an surat al-Nahl ayat: 67

今०02(2)

\&

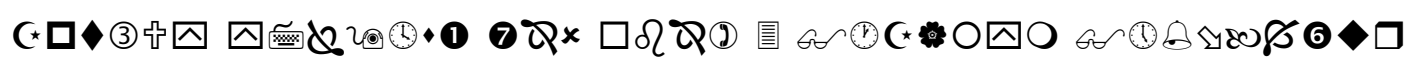

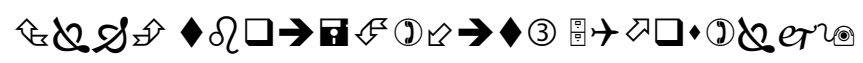

Artinya : Dan dari buah korma dan anggur, kamu buat minimuman yang memabukkan dan rezki yang baik. Sesunggguhnya pada yang demikian itu benar-benar terdapat tanda (kebesaran Allah) bagi orang yang memikirkan.

$\checkmark$ Air madu dijelaskan dalam QS al-Nahl ayat: 69

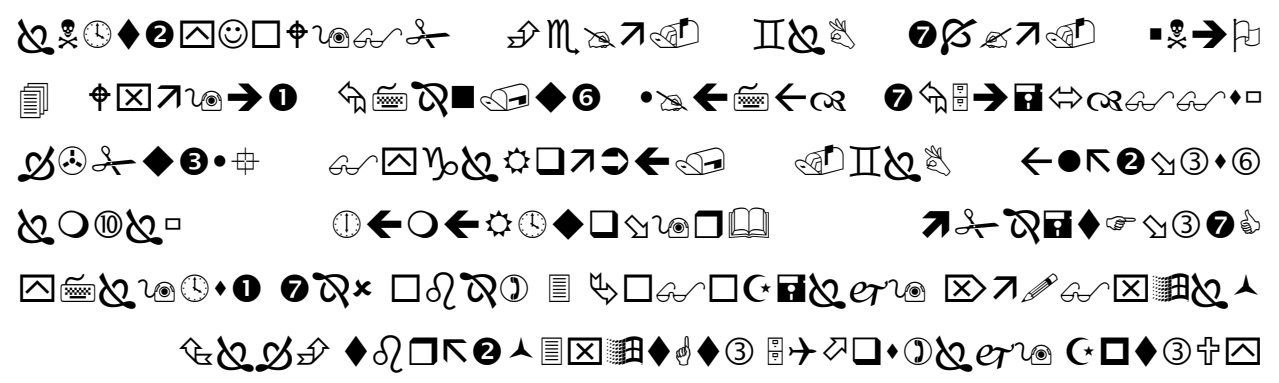

Artinya : Kemudian makanlah dari tiap-tiap (macam) buah-buahan dan tempuhlah jalan Tuhanmu yang telah dimudahkan (bagimu). dari perut lebah itu ke luar minuman (madu) yang bermacam-macam warnanya, di dalamnya terdapat obat yang menyembuhkan bagi manusia. Sesungguhnya pada yang demikian itu benar-benar terdapat tanda (kebesaran Tuhan) bagi orang-orang yang memikirkan.

Gambar 1.5

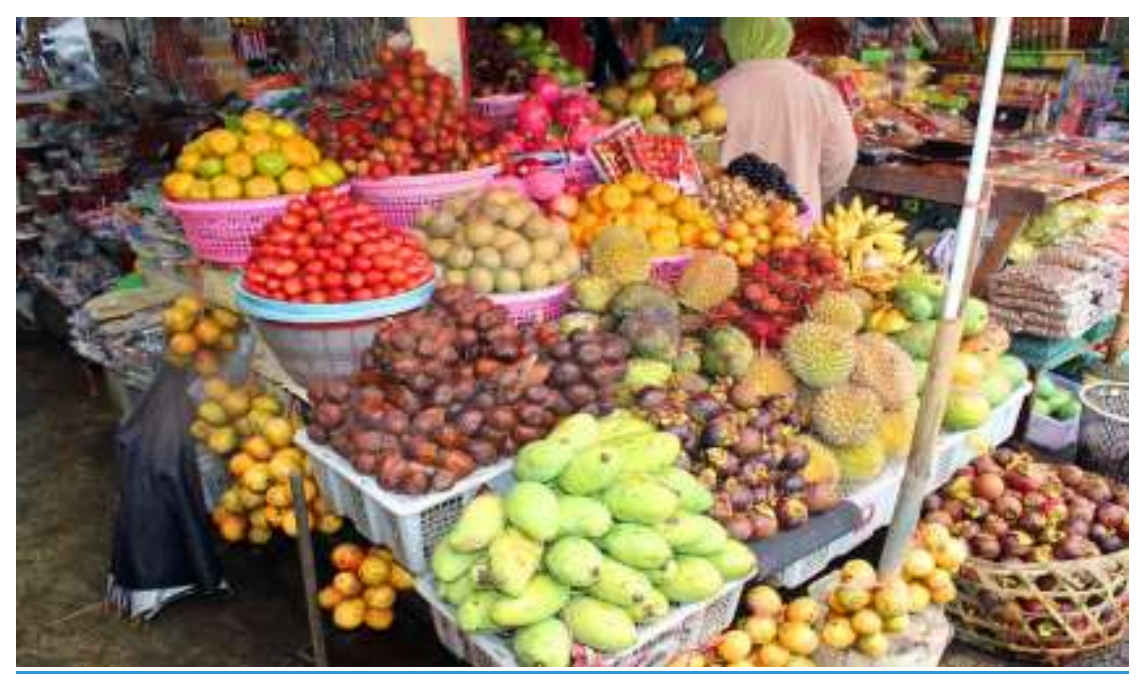


Sedangkan untuk menyalurkan dorongan seksual dibuat aturan manusia hidup dengan berpasang-pasang, dengan adanya dorongan fitrah untuk memilih pasangan hidup. Allah swt berfirman dalam Qs. al-Naba' ayat 6-8.

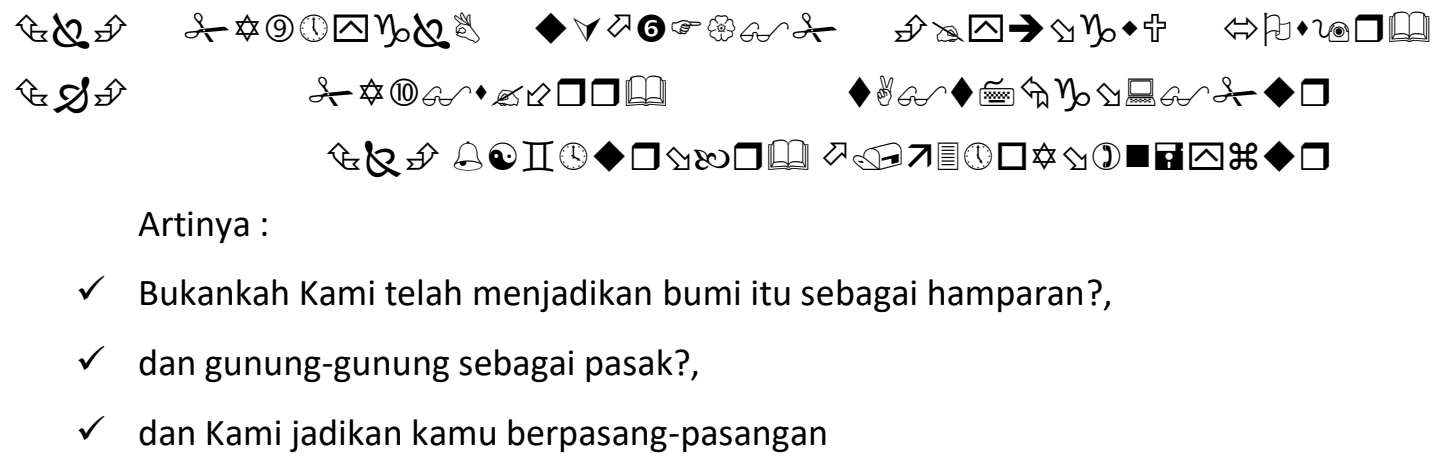

$\checkmark$ Bukankah Kami telah menjadikan bumi itu sebagai hamparan?,

$\checkmark$ dan gunung-gunung sebagai pasak?,

$\checkmark$ dan Kami jadikan kamu berpasang-pasangan

Demikian pula untuk melanjutkan dan menjaga keturunan, diatur tanggung jawab orang tua terhadap anak, dan usaha untuk memeliharanya. Tanggung jawab itu dibebankan kepada orang tua agar terhindar dari azab neraka, sebaliknya diatur pula mengenai tata krama anak kepada orang tua. Dengan mengedepankan bagimana seharusnya anak bersikap terhadap orang tua sebagai tanda bakti dan patuhnya kepada mereka. Allah swt berfirman dalam QS. al-Isra ayat: 23-25

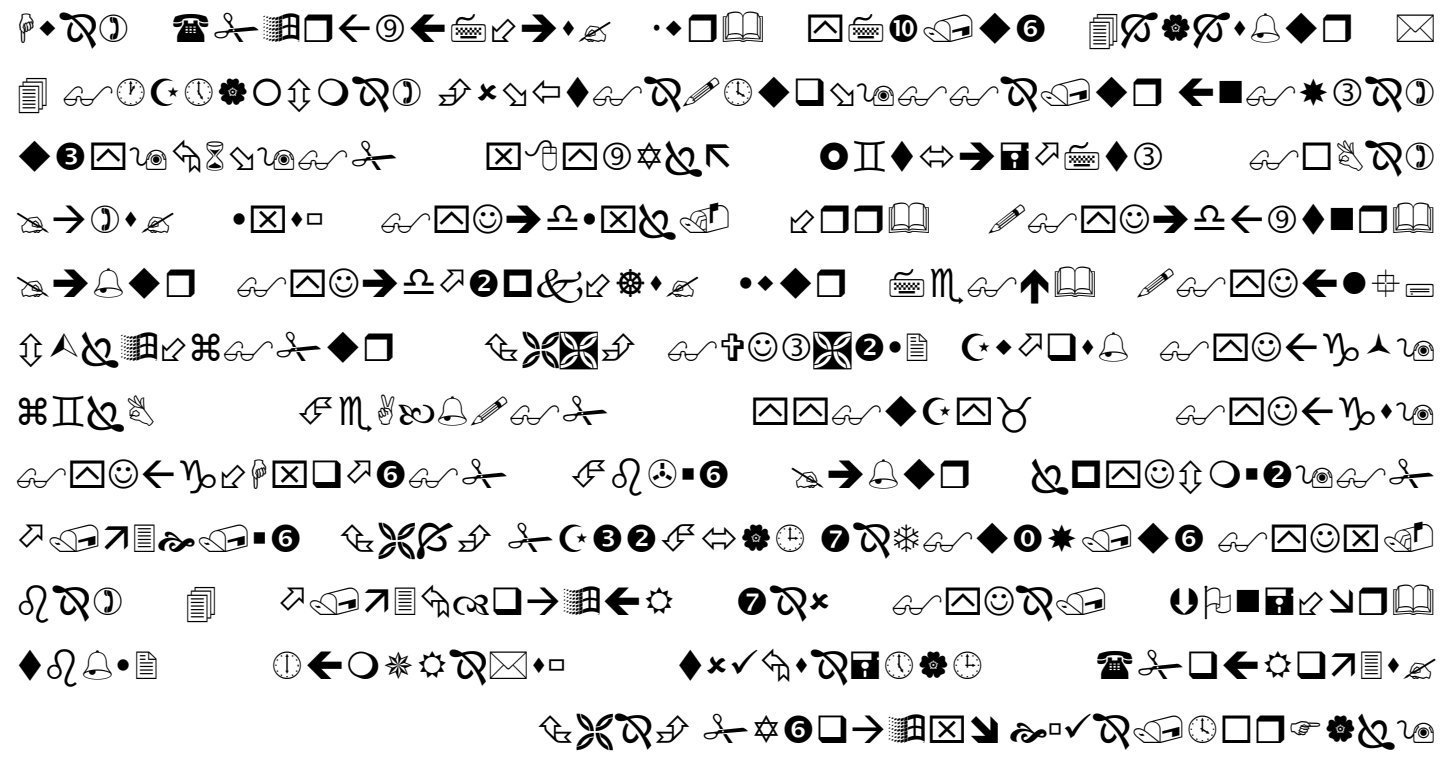

Artinya: dan Tuhanmu telah memerintahkan supaya kamu jangan menyembah selain Dia dan hendaklah kamu berbuat baik pada ibu bapakmu dengan sebaik-baiknya. jika salah seorang di antara keduanya atau Kedua-duanya sampai berumur lanjut dalam pemeliharaanmu, Maka sekali-kali janganlah kamu mengatakan kepada keduanya Perkataan "ah" dan janganlah kamu membentak mereka dan ucapkanlah kepada mereka Perkataan yang mulia. Dan rendahkanlah dirimu terhadap mereka berdua dengan penuh kesayangan dan 
ucapkanlah: "Wahai Tuhanku, kasihilah mereka keduanya, sebagaimana mereka berdua telah mendidik aku waktu kecil". Tuhanmu lebih mengetahui apa yang ada dalam hatimu; jika kamu orang-orang yang baik, Maka Sesungguhnya Dia Maha Pengampun bagi orang-orang yang bertaubat.

Dalam konsep al-Basyr ini tergambar tentang bagaimana seharusnya peran manusia sebagi makhluk biologis. Bagaimana ini harus berperan dalam upaya memenuhi kebutuhan primernya secara benar, menurut tuntunan yang telah diatur oleh penciptaNya. Sebagai makhluk biologis, manusia dibedahkan dari makhluk biologis lainya seperti hewan, yang pemenuhan kebutuhan primernya dikuasai dorongan istingtif. Sebaliknya manusia dalam kasus yang sama, didasarkan tata aturan yang baku dari Allah swt. Pemenuhan kebutuhan biologis manusia diatur dalam syari'at agama Allah swt. ${ }^{7}$

\section{Konsep al-Insan}

Kata al-Insan bukan berarti basyar saja dan bukan pula dalam pengertian al-ins. Dalam pemakaian al-Qur'an, al-Insan mengandung penegrtian makhluk "mukallaf (ciptaan Tuhan yang dibebani tanggung jawab) pengemban amanah Allah swt dan Khalifah Allah swt di atas bumi.

Al-Insan dalam pengertian ini didapati pada 65 tempat dalam Al-Qur'an. Penjelasan tersebut menunjukkan keistimewaan dan ciri-ciri manusia dalam pengertian al-Insan. Terdapat tiga kali dalam al-Qur'an surah al-Alaq yang menyebut kalimat al-Insan, yaitu: pertama, menceritakan bahwa manusia diciptakan dari al-Alaq (segumpal darah, kedua manusia dikatakan memiliki keistimewaan yaitu ilmu, dan ketiga Allah swt menggambarkan bahwa manusia dengan segala keistimewaannya telah melampaui batas karena telah merasa

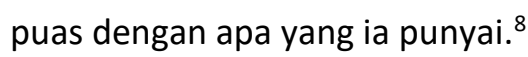

Al-Insan terbentuk dari akar kata nasiya yang berarti lupa (M. Quraish Sihab 1996:60). Penggunaan kata al-Insan sebagai kata bentukan yang termuat dalam Al-quran, mengacu kepada potensi yang dianugrahkan Allah kepada manusia. Potensi tersebut antara lain berupa potensi untuk bertumbuh dan berkembang secara fisik (Qs.23:12-14) dan juga potensi untuk bertumbuh dan berkembang secara mental spiritual.

Perkembangan tersebut antara lain, meliputi kemampuan untuk berbicara (Qs. 55:4) menguasai ilmu pengetahuan melalui proses tertentu, dengan mengajarkan manusia dengan kalam (baca tulis), dan segala apa yang diketahuinya (Qs. 96:4-5), kemampuan untuk

\footnotetext{
${ }^{7}$ Jalaluddin, Teologi Pendidikan, (Jakarta: Raja Grafindo Persada, 2003), 20-21.

${ }^{8}$ Dewan Redaksi Ensiklopedi Islam, Ensiklopedi Islam, hlm.162
} 
mengenal Tuhan atas dasar perjanjian awal di alam ruh, dalam bentuk kesaksian (QS.7:172). Potensi untuk mengembangkan diri ini (yang positif) member peluang bagi manusia untuk mengembangkan kualitas sumber daya insaninya. Dengan cara menumbuh kembangkan potensi yang dimilikinya secara optimal, diharapkan manusia dapat menjadi makhluk ciptaan yang mengabdi kepada penciptanya, melalui berbagi kemampuan kreatif dan inovatif yang ia miliki.

Selain memiliki potensi yang positif, manusia juga dibekali dengan sejumlah potensi lain yang berpeluang untuk mendorong manusia kearah tindakan, sikap serta prilaku negatif dan merugikan. Potensi tersebut antara lain ditampilkan dalam bentuk kecenderungan manusia untuk berlaku dzalim dan mengingkari nikmat (QS. 14:34), tidak berterima kasih dan muda putus asa (QS. 11:9), sombong bila telah berkecukupan. Perilaku ini cenderung menjadikan manusia lupa diri, dan melupakan harkat serta martabat dirinya sebagai makhluk ciptaan.

Kecenderungan yang negatif ini bagaimanapun akan merugikan dan serta menghambat potensi manusia. Karenanya sebagi hamba Allah swt, manusia diharapkan mampu mengatasi hambatan potensi-potensi negatif tersebut. Meskipun potensi negatif tadi tidak mungkin dihilangkan sama sekali, tetapi dalam menumbuhkembangkan diri hendaknya manusia tidak larut dalam bawaan arus dorongan yang negatif itu yang akan dapat merugikan dirinya. ${ }^{9}$

Sebagai makhluk alternatif manusia diciptakan oleh Allah swt diharapkan dapat berperan dalam mengembangkan dirinya atas dasar potensi fitrahnya itu.

Menurut M.Qurais Sihab, setidaknya ada tiga kecenderungan fitrah manusia yaitu: benar, baik, dan indah. Fitrah sebagi potensi yang terbawa sejak lahir itu, mendorong manusia untuk selalu berbuat baik, benar, dan indah. Fitrah merupakan gabungan dari tiga unsur itu. Mencari yang indah, mencari yang baik, menimbulkan etika, dan mencari yang benar menghasilkan ilmu.

Potensi manusia menurut konsep al-Insan diarahkan pada upaya mendorong manusia untuk beraksi dan berinovasi. Dan kreatifitasnya, manusia dapat menghasilkan sejumlah kegiatan berupa pemikiran (ilmu pengetahuan), kesenian, ataupun benda-benda ciptaan. Kemudian melalui kemampian berinovasi, manusia mampu merekayasa temuan-temuan baru dalam berbagai bidang produk teknologi. Dengan demikian manusia dapat menjadikan dirinya sebagai makhluk berbudaya dan berperadaban. ${ }^{10}$

\footnotetext{
9 Jalaluddin, Teologi Pendidikan, (Jakarta: PT Raja Grafindo Persada, 2003), 21-22.

${ }^{10}$ Jalaluddin, Teologi Pendidikan, (Jakarta: Raja Grafindo Persada, 2003), 22-23.
} 


\section{Konsep An-Nas}

Dalam al-Quran kosa kata al-Nas umumnya dihubungkan dengan fungsi manusia sebagi makhluk sosial. Manusia diciptakan sebagai makhluk bermasyarakat, yang berawal dari pasangan laki-laki dan wanita, kemudian berkembang menjadi suku-suku dan berbangsabangsa, untuk saling kenal mengenal (QS.49:13). Manusia merupakan makhluk sosial yang secara fitrah senang hidup berkelompok, sejak dari bentuk satuan yang terkecil (keluarga) hingga yang paling besar dan kompleks, yaitu bangsa dan umat manusia.

Sejalan dengan konteks kehidupan sosial ini, maka peran manusia dititikberatkan pada upaya untuk menciptakan keharmonisan hidup masyarakat. Masyarakat dalam ruang lingkup yang paling sederhana yaitu keluarga, hingga ke ruang lingkup yang lebih luas lagi yaitu sebagi warga antar bangsa. Keluarga sebagai unit sosial yang paling kecil, terdiri atas ayah, ibu dan anak-anaknya. Sedangkan dalam konteks bangsa dan umat, terdiri atas kelompok komunitas, etnis, ras, maupun suku.

Di dalam keluarga peran sosial manusia ditekankan pada pembentukan diri, yang sesuai dengan fungsi dan peran setiap anggota dalam keluarga. Ayah berperan selaku pemimpin dalam rumah tangga, Ibu sebagai pengasuh dan pembimbing putra-putrinya. Sebaliknya putra-putrinya diarahkan untuk berperan sebagai anak saleh, hormat dan patuh kepada kedua orang tuanya. Pada tatanan peranan tersebut diharapkan kehidupan dalam keluarga akan terjalin secara harmonis, dan penuh perhatian. Masing-masing anggota keluarga mampu menjalankan kewajiban dan tanggung jawab masing-masing sesuai dengan status dan fungsi yang dibebankan kepadanya.

Untuk mengatur dan menjaga ketertiban dalam hubungan sosial tersebut, lazimnya ada seorang tokoh yang ditunjuk selaku pemimpin, baik dalam lingkungan pergaulan antar tetangga, kampong atau sebagai pemimpin bangsa. Sejalan dengan kedudukan itu seorang tokoh dituntut untuk harus memerankan diri sebagai pemimpin orang banyak (masyarakat). Artinya ia harus mampu memerankan dirinya sebagai pelayan kepentingan kehidupan masyarakat. Dalam kaitan inilah tampaknya, bahwa setiap manusia secara umum dibebankan tanggung jawab. Setiap orang adalah pemimpin dan harus mempertanggung jawabkan kepemimpinannya.

Sejalan dengan adanya tanggung jawab tersebut maka, konsep al-Nas selalu mengacu kepada peran manusia dalam kehidupan sosial. Manusia diarahkan agar menjadi warga sosial yang diharapkan dapat memberi manfaat dalam kehidupan bersama di masyarakat. Nabi 
Muhammad saw menyatakan: sebaik-baik manusia adalah mereka yang banyak memberi manfaat bagi semua manusia (Khair al-Nas anfa'uhum li al-Nas). ${ }^{11}$

Sebagai makhluk ciptaan Allah swt bagaimanapun manusia dituntut untuk beriman dan tunduk kepada penciptanya. Kemudian dalam kehidupan sosial mereka dituntut untuk berbuat kebaikan. Kerangka pokok peran manusia yang digariskan penciptanya adalah:

1. Mengajak masyarakat berbuat baik (setelah dirinya terlebih dahulu melakukan kebaikan),

2. Mencegah masyarakat berbuat kemungkaran (sebelum perbuatan munkar terjadi)

3. Memiliki dan menaati apapun atas dasar iman kepada Allah swt.

Ketiga kerangka pokok tersebut merupakan persyaratan bagi pembentukan kehidupan sosial yang paling utama. Jika ketiganya sudah dilakukan secara konsisten dan berkesinambungan serta dapat dijadikan tradisi dalam kehidupan sosial, maka kelompok masyarakat tersebut sebagai yang dijanjikan Allah swt, akan berpeluang menjadi umat yang baik (QS.3:110). Dan peringkat tersebut yaitu predikat khairu ummat memang sudah pernah dicapai oleh Nabi Muhammad dan para sahabat pada periode-periode awal perkembangan masyarakat Islam, khususnya di periode Madinah. Keberhasilan ini digambarkan sebagai kehidupan masyarakat "Baldatun Thayyibatun wa Rabbun Ghafur" (Negara yang aman tentram dibawah naungan ampunan Allah swt). ${ }^{12}$

\section{Konsep Bani Adam}

Dalam konteks ini ayat-ayat yang mengandung konsep Bani Adam, manusia diingatkan Allah swt agar tidak tergoda oleh setan (QS.7;26-27). Pencegahan dari makan minum yang berlebihan dan tata cara berpakain yang pantas saat beribadah (QS.7:31), bertaqwa dan mengadakan perbaikan (QS.7:35), kesaksian manusia terhadap Tuhannya (QS.7:172), dan terahkir peringatan agar manusia tidak terpedaya hingga menyembah setan, dengan mewanti-wanti manusia mengenai status setan sebagai musuh yang nyata (QS.36:60).

Penjelasan ayat-ayat di atas mengisyaratkan, bahwa manusia selaku Bani Adam dikaitkan dengan gambaran peran Adam As. Saat awal diciptakan. Pada saat Adam As akan diciptakan, maka para malaikat seakan mengkhawatirkan kehadiran makhluk ini. Mereka memperkirakan dengan penciptaannya, manusia akan menjadi biang kerusakan dan pertumpahan darah (QS.2:30). Kemudian terbukti bahwa Adam As. dan istrinya hawa karena

${ }^{11}$ Jalaluddin, Teologi Pendidikan, (Jakarta: Raja Grafindo Persada, 2003), 23-25.

12 Jalaluddin, Teologi Pendidikan, (Jakarta: PT Raja Grafindo Persada, 2003), 25-26. 
kekeliruan akhirnya terjebak oleh hasutan setan hingga oleh Allah swt, keduanya dikeluarkan dari surga sebagai hukuman atas kelalaian yang mereka perbuat (QS.2:35-36).

Lebih dari itu, konsep Bani Adam dalam bentuk menyeluruh mengacu kepada penghormatan kepada nilai-nilai kemanusiaan. Konsep ini menitikberatkan pada upaya pembinaan hubungan persudaraan antar sesama manusia. Menyatukan visi bahwa manusia pada hakikatnya berawal dari nenek moyang yang sama, yaitu Adam As. Dengan demikian manusia, apa pun latar belakang sosio-kultural, agama, bangsa, dan bahasanya, harus dihargai dan dimuliakan. Dalam tataran ini manusia seakan berstatus sebagai sebuah keluarga yang bersudara, karena berasal dari nenek moyang yang sama.

Penghargaan dan pemuliaan tali persaudaraan sedarah ini sekaligus menyiratkan pengakuan terhadap nilai-nilai hak asasi manusia (HAM) yang paling murni dan esensial. Konsep Bani Adam mencakup perlindungan terhadap HAM tersebut, agar manusia tidak teraniaya hanya karena perbedaan latar belakang yang disandangnya. Konsep Bani Adam sarat akan muatan nilai-nilai humanis yang hakiki, dalam ruang lingkup kehidupan global. Suatu bentuk kehidupan masyarakat manusia yang didasarkan pada penghargaan terhadap nilai-nilai fitrah kemanusiaannya yang asasi. ${ }^{13}$

\section{Konsep Al-Ins}

Al-Ins adalah homonim dari al-jins dan al-nufur. al-Insan terbentuk dari akar kata Ins berarti senang, jinak dan harmonis, atau akar kata nisy yang berarti lupa, serta dari akar kata naus berarti "pergerakan atau dinamis".

Untuk melihat bagaimana konsep al-Ins ini dipahami, seperti dikemukakan al-Quran, bahwa jin dan manusia diciptakan untuk mengabdi kepada Allah (QS.51:56). Berangkat dari hakikat itu. la dituntut agar dapat memerankan dirinya sebagai pengabdi Allah swt secara konsisten dengan ketaatan penuh. Ketaatan kepada Allah swt merupakan peran puncak manusia dalam segala aspek kehidupannya, karena atas dasar dan tujuan tersebut pulalah ia diciptakan.

Gambar 1.6

${ }^{13}$ Jalaluddin, Teologi Pendidikan, (Jakarta: PT Raja Grafindo Persada, 2003), 26-27. 


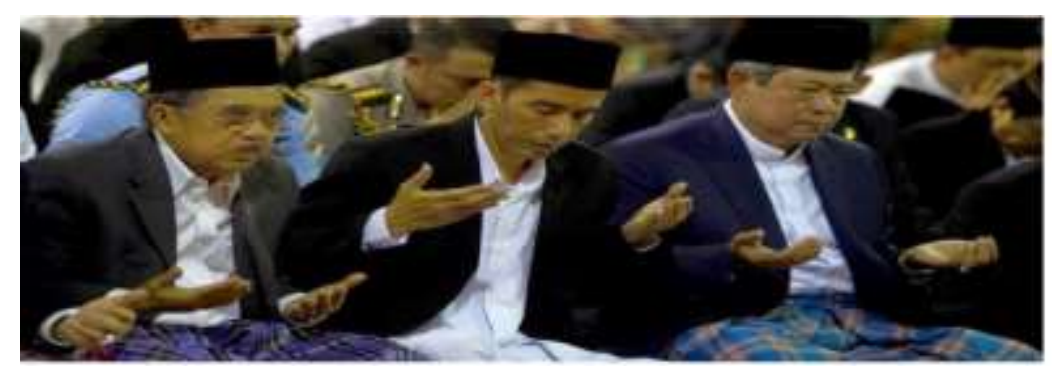

JK: YA ALLAH SAYA SIAP MEMBANTU JOKOWI MENSEJAHTERAKAN RAKYAT JOKOWI : YA ALLAH TUNTUN HAMBAMU INI MENJADI PRESIDEN YANG BAIK SBY : YA ALLAH SAYA TITIPKAN INDONESIA KEPADA JOKOWI AGAR LEBIH BAIK LAGI AMIN..AMIN..AMIN..AMIN..AMIN..AMIN...AMIN..

Adapun upaya untuk menyelaraskan pola tingkah laku manusia dengan tututan ini, di harapkan ia selalu mengingat Allah swt. Dengan demikian setiap aktifitas kehidupannya diharapkan dapat terkategorikan sebagai amal ibadah. Sebagai pemantapan ikatan kepada Allah swt ini pula, sangat dianjurkan kepada manusia agar mengawali setiap aktifitasnya dengan bacaan Bismillah. Manusia dianjurkan untuk membiasakan dirinya senantiasa mengingat Allah swt dalam keseharian hidup yang dilakoninya.

Ucapan Bismillah mengandung arti antara lain, bahwa aktifitas manusia tidak bebas nilai semua digantungkan kepada penciptanya. Dengan demikian melalui ucapan Bismillah yang dilafadzkan, sekaligus mengandung arti bahwa, manusia berupaya memasukan nilai-nilai Ilahiyat pada segenap kegiatan dan aktivitasnya. Ucapan tersebut seakan mempertalikan dirinya melalui keteringatan kepada sang pencipta, sehingga segala bentuk aktivitas yang akan dilakukan senantiasa berada dalam garis tuntutan serta ridha-Nya. ${ }^{14}$

Manusia terdiri dari dua karakter utama, yaitu pengabdian atau penghambaan dan kekhalifahan. Sebagai khalifah, manusia dituntut aktif dalam posisi sebagai wakil Allah swt dan melaksanakan kehendaknya di dunia. ${ }^{15}$

Kedudukan manusia di alam raya ini di samping sebagai khalifah yang memiliki kekuasaan untuk mengolah alam dengan menggunakan segenap daya dan potensi yang dimilikinya, juga sekaligus sebagai 'abd, yaitu seluruh usaha dan aktifitasnya itu harus dilaksanakan dalam rangakaian ibadah kepada Allah swt. Dengan pandangan yang terpadu ini, maka sebagai seorang khalifah tidak akan berbuat sesuatu yang mencerminkan kemunkaran atau bertentangan dengan kehendak Tuhan. Untuk dapat melaksanakan fungsi kekhalifahan dan ibadah dengan baik ini manusia perlu diberikan pendidikan, pengajaran, pengalaman, ketrampilan, teknologi, dan sarana pendukung lainnya. Hal ini menunjukkan bahwa konsep kekhalifahan dan ibadah dalam al-Quran erat kaitannya dengan pendidikan. Manusia yang dapat

\footnotetext{
14 Jalaluddin, Teologi Pendidikan, (Jakarta: PT Raja Grafindo Persada, 2003), 28-29.

${ }^{15}$ Rafy Sapuri, Psikologi Islam: Tuntunan Jiwa Modern, (Jakarta: PT Raja Grafindo Persada, 2009), 348.
} 
melaksanakan fungsi-fungsi yang demikian itulah yang diharapkan muncul dari kegiatan usaha pendidikan. ${ }^{16}$

Kemudian sebagai manusia yang telah memperoleh pendidikan, tidak benar cendekiawan muslim hanya duduk berpangku tangan, melakukan pekerjaan rutinitas di dalam profesi dan kantornya, dan membiarkan masyarakat merintih kesakitan dan menderita karena adanya penindasan, pemerasan tenaga, dominasi materi, penyelewengan tugas, perilaku non konstitusional, dan kerenggangan-kerenggangan sosial lainnya. Minimal mereka harus bisa melakukan perlawanan, menjelaskan bentuk-bentuk penyelewengan yang tidak benar dan akibat dari praktek-praktek tersebut, serta bagaimana seharusnya tradisi harus dilakukan, baik sebagai individu, pekerja, anggota masyarakat, warga Negara, maupun sebagai seorang yang beragama. Tidak puas hanya sebagai pengamat praktek kehidupan, tetapi selalu berusaha sebagai pelaku aktif didalamnya. ${ }^{17}$

\section{B. MANUSIA SEBAGAI HAMBA ALLAH (ABDULLAH)}

Al-Quran juga menamakan manusia dengan Abdu Allah yang berarti hamba Allah. Manusia disebut Abdu Allah juga disertakan dengan konteks makna kata tersebut. Selain itu menurut Al-Raghib al-Isfahani, kata Abdu juga bermakna ibadah, sebagai pernyataan kerendahan diri. Ibadah kepada Allah swt merupakan sikap dan pernyataan kerendahan diri yang paling puncak dan sempurna dari seorang hamba. Kemudian ibadah itu sendiri berupa pengabdian yang hanya diperuntukkan kepada Allah swt semata, baik ibadah yang bersifat spontanitas maupun yang didasarkan atas perintah-Nya.

Dalam pandangan Ja'far al-Shadiq, ibadah adalah sebagai pengabdian kepada Allah swt baru dapat terwujud bila seseorang dapat memenuhi tiga hal; 1 . Menyadari sepenuhnya bahwa apa yang dimiliki termasuk dirinya sendiri adalah milik Allah swt dan berada di bawah kekuasaan Allah swt 2. Menjadikan segala bentuk sikap dan aktifitasnya senantiasa mengarah pada usaha untuk memenuhi perintah Allah swt dan menjauhi segala bentuk perbuatan yang dicegah atau dilarang-Nya, 3. Dalam mengambil suatu keputusan senantiasa mengaitkan dengan restu dan pedoman yang ditentukan Allah swt.

Dalam konteks konsep Abdu Allah ini ternyata peran manusia harus disesuaikan dengan kedudukannya sebagai abdi (hamba). Hal ini berarti bahwa, manusia harus menempatkan diri sebagai yang dimiliki, tunduk dan taat kepada semua ketentuan pemilik, yaitu Allah swt. Sebagai pernyataan penghambaan dirinya, manusia harus dapat menempatkan dirinya sebagai pengabdi

\footnotetext{
${ }^{16}$ Abbudin Nata, Filsafat Pendidikan Islam, (Ciputat: Logos Wacana Ilmu, 1997), 41.

${ }^{17}$ Imam Bawani dan Isa Anshori, Cendekiawan Muslim Dalam Perspektif Pendidikan Islam, (Surabaya: Bina Ilmu, 1991), 49-50.
} 
Allah swt dengan sungguh-sungguh dan secara ikhlas. Kemampuan ini tergambar dari pola sikap dan prilakunya, yaitu apakah ia sanggup untuk memainkan peran tersebut secara baik atau tidak. Dalam hubungan ini peran yang dimainkan manusia terkait erat dengan ridha Allah swt. Maksudnya, apa saja aktifitas manusia dalam hubungan antar manusia atau antar sesama makhluk selalu harus atas dasarnya ridha Allah swt. ${ }^{18}$

Sebagai seorang hamba, manusia harus tetap tunduk kepada-Nya. Bilamana manusia hendak melakukan hubungan dengan Allah, terlebih dahulu harus mengetahui apa yang dikehendaki oleh-Nya, agar dapat melakukan sesuai dengan kehendaknya. Allah swt menghendaki agar seluruh manusia beribadah kepada-Nya. Kata ibadah artinya melayani. Jadi, tujuan penciptakan manusia adalah ibadah dan pelayanan pada Allah, maka dengan melaksanakan kehendak-Nya ia menjadi manusia seutuhnya. ${ }^{19}$ Manusia diciptakan Allah swt untuk mengabdi kepada-Nya. Tugas manusia untuk mengabdi kepada Allahswt dengan tegas dinyatakannya dalam Firman-Nya:

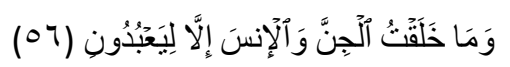

"Dan Aku tidak menciptakan jin dan manusia melainkan supaya mereka menyembah-Ku." (QS. Adh-Dhariyat [51] : 56).

Mengabdi kepada Allah swt dapat dilakukan manusia melalui dua jalur, jalur khusus dan jalur umum. Pengabdian melalui jalur khusus dilaksanakan dengan melakukan ibadah khusus, yaitu segala upacara pengabdian langsung kepada Allah swt yang cara dan waktunya telah ditentukan oleh Allah swt sendiri dengan rinciannya dijelaskan oleh Rasul-Nya, seperti yang ada dalam rukun Islam. Pengabdian melalui jalur umum dapat diwujudkan dengan melakukan perbuatan-perbuatan baik yang disebut amal shaleh, yaitu segala perbuatan yang bermanfaat bagi diri sendiri dan masyarakat, dengan niat ikhlas untuk mencari keridhaan Allah swt. ${ }^{20}$ Dengan memahami surat Adz-zariyat, hendaknya manusia dapat mengambil pelajaran bahwa:

1. Menyadari bahwa hidup di dunia bukanlah tujuan, melainkan sebagai kesempatan beramal baik untuk menuju hidup bahagia di akhirat kelak.

2. Kesempatan hidup hendaknya dimanfaatkan untuk menghambakan diri kepada-Nya dalam seluruh aspek hidupnya.

3. Kenikmatan berupa kesenangan hidup di dunia jangan sampai melupakan tugas pokok hidup, yakni menghambakan diri kepada Allah semata.

\footnotetext{
${ }^{18}$ Jalaluddin, Teologi Pendidikan, (Jakarta:Raja Grafindo Persada, 2003), 29-30.

${ }^{19}$ Rafy Sapuri, Psikologi Islam: Tuntunan Jiwa Modern, (Jakarta: Raja Grafindo Persada, 2009), 352.

${ }^{20}$ Mohammad Daud Ali, Pendidikan Agama Islam, (Jakarta: Raja Grafindo Persada, 2013).13-14.
} 
Pengakuan manusia akan adanya Allah secara naluriah menurut informasi Al-Qur'an disebabkan telah terjadinya dialog antara Allah swt dan roh manusia tatkala ia berada di alam arwah. Firman Allah swt :

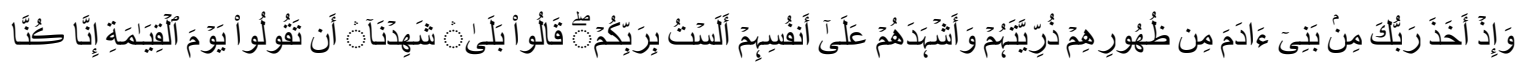

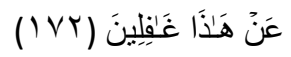
Artinya : "Dan [ingatlah], ketika Allahmu mengeluarkan keturunan anak-anak Adam dari sulbi mereka dan Allah mengambil kesaksian terhadap jiwa mereka [seraya berfirman]: "Bukankah Aku ini Allahmu?" Mereka menjawab: "Betul [Engkau Allah kami], kami menjadi saksi". [Kami lakukan yang demikian itu] agar di hari kiamat kamu tidak mengatakan: "Sesungguhnya kami [bani Adam] adalah orang-orang yang lengah terhadap ini [keesaan Allah]". (QS. AI-A'raf [7]: 172).

Dengan demikian, kepercayaan dan ketergantungan manusia dengan Allah swt tidak bisa dipisahkan dari kehidupan manusia itu sendiri. Pengenalan dan pengabdian yang dilakukan manusia kepada Allah pada mulanya mereka lakukan sesuai dengan keterbatasan akalnya. Allah tidak ingin manusia berada selalu dalam kesesatan. Untuk itu Allah memperkenalkan manusia tentang dirinya melalui wahyu-Nya. Sehingga manusia dapat melaksanakan pengabdian sesuai aturan yang dikehendaki Allah swt.

Allah swt juga mengutus para Rasul-Nya sebagai pemberi jalan menuju petunjuk kepada manusia mana yang harus mereka sembah sebenarnya dan mana yang tidak boleh disembah. Lewat instingtinya "naluri fitriyah" pengakuan akan adanya Dzat yang menguasai, Akal, bimbingan wahyu (ajaran agama) yang disampaikan dengan perantaraan para rasul manusia diharapkan mampu mengenal khaliqnya lewat pengabdian yang ditunjukkan dalam kehidupan. ${ }^{21}$

\section{MANUSIA SEBAGAI KHALIFAH ALLAH (KHALIFATULLAH)}

Sebelum manusia diciptakan, Allah swt telah mengemukakan rencana penciptaan tersebut kepada malaikat. Pernyataan Allah ini terangkum dalam al-Qur'an surat al-Baqarah ayat 30

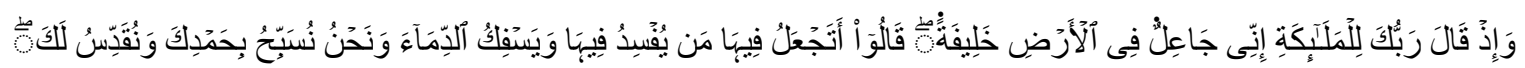

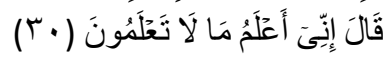
"Ingatlah ketika Allahmu berfirman kepada para malaikat: "Sesungguhnya Aku hendak menjadikan seorang khalifah di muka bumi". Mereka berkata: "Mengapa Engkau hendak menjadikan [khalifah] di bumi itu orang yang akan membuat kerusakan padanya dan menumpahkan darah, padahal kami senantiasa bertasbih dengan memuji Engkau dan mensucikan Engkau?" Allah berfirman: "Sesungguhnya Aku mengetahui apa yang tidak kamu ketahui". (QS. Al-Baqarah [2]: 30).

\footnotetext{
${ }^{21}$ Edi Purwanto dan Suyadi, Pendidikan Agama Islam, (Surakarta : Widya Duta, 2004), 3.
} 
Dalam hal ini mengandung maksud bahwa" sesungguhnya Aku (Allah swt) berhak menjadikan seseorang Khalifah di muka bumi", Untuk melakukan tugas-tugas kekhalifahan itu Allah swt tidak membiarkan makhluk ciptaan-Nya itu dalam keadaan kosong atau tanpa dibekali apapun. Manusia dilengkapi Allah swt dengan berbagai potensi, antara lain; bekal pengetahuan (QS.2:31).

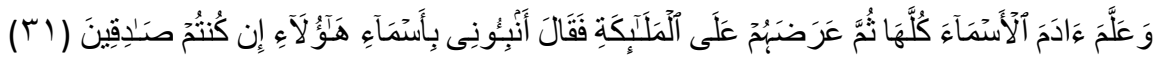

Artinya: Dan Dia mengajarkan kepada Adam nama-nama [benda-benda] seluruhnya, kemudian mengemukakannya kepada para Malaikat lalu berfirman: "Sebutkanlah kepada-Ku nama bendabenda itu jika kamu memang orang-orang yang benar!" (QS. Al-Baqarah [2]: 31).

Pada hakekatnya eksistensi manusia dalam kehidupan ini adalah untuk melaksanakan tugas kekhalifahan yaitu membangun dan mengelola dunia tempat hidupnya ini sesuai dengan kehendak pencipta. Tugas kekhalifahan tersebut memang sangat berat. Namun status ini menunjukan peran manusia sebagai penguasa di bumi atas petunjuk Allah swt. Selain itu, dari tugas tersebut tergambar pula sekaligus kedudukan manusia selaku makhluk ciptaan-Nya yang paling mulia.

Beranjak dari pemahaman makna yang termuat didalamnya, barangkali akan jelas bagaimana peran yang harus dilaksanakan manusia menurut statusnya selaku khalifah Allah swt. Dalam mewujudkan hubungan horisontal (sesama makhluk ciptaan Allah swt) hendaknya menempatkan diri sebagai pemelihara perdamaian, persaudaraan, dan pemersatu masyarakat bukan hubungan atas dasar penakluk dengan yang ditaklukkan. Hubungan yang ramah dan saling menguntungkan, bukan sebaliknya, yaitu hubungan atas dasar saling bermusuhan dan merugikan. ${ }^{22}$

Adapun hubungan vertical, menggambarkan bagaimana manusia berperan sebagai mandataris Allah swt. Dalam peran ini manusia penting menyadari bahwa kemampuan yang dimilikimya untuk menguasai alam dan sesama manusia adalah karena penugasan dari penciptanya. Dengan demikian tugas itu meliputi cara bagaimana manusia dapat berperan sebagai pengemban amanat tersebut sebaik mungkin. Dari peran ini diharapkan manusia dapat menciptakan kondisi kehidupan yang harmonis di muka bumi.

Allah SWT telah menciptakan tatanan kehidupan yang harmonis dengan neraca keadilan (QS.55:9), menyediakan kebutuhan hidup manusia yang beraneka ragam (QS.55: 11-12), semuanya itu merupakan nikmat Tuhan yang mustahil didustakan (QS.55:13). Karena manusia cenderung untuk melupakan nikmat-nikmat tersebut, maka Allah swt memperingatkan mereka.

${ }^{22}$ Jalaluddin, Teologi Pendidikan, (Jakarta: PT Raja Grafindo Persada, 2003), 30-31. 
Allah swt juga memperingatkan manusia akan kerusakan yang terjadi di daratan maupun di lautan sebagai akibat dari ulah tangan manusia (QS. 30:41). Dalam statusnya sebagai khalifah Allah swt, manusia dituntut untuk menjaga dan melestarikan keharmonisan tatanan yang sudah ada. ${ }^{23}$

Allah swt yang Maha Kuasa yang Maha Sempurna, Pencipta manusia dan Penguasa Jagat Raya, menyatakan pada para malaikat bahwa Dia ingin menciptakan wakilnya diatas bumi serta menunjuk manusia sebagai khalifah. Di atas bumi ini manusia mengemban misi untuk mewakili Allah swt dan mencerminkan kualitas-kualitas-Nya. Dan ini merupakan sifat utama terpenting manusia yang dimilikinya diantara segala makhluk yang telah diciptaan Allah swt. ${ }^{24}$

Manusia adalah wakil Allah swt (Khalifatullah) di Bumi, memiliki kemampuan untuk mengetahui segala sesuatu, menundukkan Bumi, diberikan kekuasaan untuk melakukan kebaikan di bumi. Menurut Hadits yang popular, bahwa Allah swt menciptakan manusia sesuai dengan bentuk-Nya. Maksud bentuk disini bukan gambaran fisik. Melainkan mencerminkan nama-nama dan sifat Allahswt.

Menurut pandangan Islam, manusia termasuk dalam tiga jenis wahyu besar, yaitu alam raya, diri manusia dan Agama. Tiga faktor itu disebut "Kitab" maksudnya adalah kitab alam untuk dibaca dan dijelaskan, dan ada kitab jiwa yang ada dalam diri manusia, dan terakhir kitab suci yang untuk menunjuki manusia sebagai dasar dari berbagai agama dan sebagai kunci untuk membaca kedua kitab alam semesta dan jiwa.

Hak manusia adalah sentral di muka bumi. Manusia dipilih sebagai wakil Allah (Khalifatullah) sekaligus hambanya (Abdullah). Sebagai seorang hamba, manusia harus tetap tunduk kepada-Nya. Sebagai wakil-Nya, manusia harus aktif didunia untuk menjalankan kehendak-Nya diatas muka bumi ini. ${ }^{25}$

Allah swt menciptakan alam semesta tidak sia-sia, penciptaan manusia bertujuan jelas yaitu dijadikan sebagai khalifah atau penguasa (pengatur bumi) untuk memakmurkan kehidupan di bumi sesuai dengan petunjuknya. ${ }^{26}$

Manusia diciptakan Allah swt untuk menjadi Khalifah-Nya di Bumi. Allah swt menciptakan Manusia untuk menjadi Khalifahnya di Bumi. Perkataan menjadi Khalifah dalam ayat tersebut mengandung makna bahwa Allah swt menjadikan manusia wakil atau pemegang kekuasaan-Nya mengurus dunia dengan melaksanakan segala yang diridhainya dimuka bumi ini. ${ }^{27}$

\footnotetext{
${ }^{23}$ Ibid., 31-32.

${ }^{24}$ Ali Shariati, Tugas Cendekiawan Muslim, (Jakarta: PT. Raja Grafindo Persada, 1996), 5.

${ }^{25}$ Rafy Sapuri, Psikologi Islam: Tuntunan Jiwa Modern, (Jakarta: Raja Grafindo Persada, 2009), $350-351$.

${ }^{26}$ Ramayulis, Ilmu Pendidikan Islam, (Jakarta : Kalam Mulia, 2008), 9.

${ }^{27}$ Mohammad Daud Ali, Pendidikan Agama Islam, (Jakarta: Raja Grafindo Persada, 2013), 13-14
} 
Dalam melaksanakan tugas sebagai khalifah manusia harus selalu berpedoman kepada petunjuk yang telah diberikan Allah swt. Dengan memahami surat al-Baqarah ayat 30 diatas, hendaknya manusia berperilaku yang mencerminkan:

1. Kesadaran akan tugas hidupnya sebagai pengatur bumi.

2. Berbuat baik kepada sesama manusia dan terhadap makhluk yang lain.

3. Semaksimal mungkin untuk menghindari perbuatan yang dapat menimbulkan kerusakan bagi siapapun.

4. Berusaha untuk mewujudkan islah atau perdamaian di bumi dan menghindari pertikaian yang akan membawa kerusakan.

Dalam mengurus dunia, sesungguhnya manusia diuji apakah manusia melaksanakan tugasnya dengan baik atau tidak. Mengurus dengan baik adalah mengurus kehidupan dunia ini sesuai dengan kehendak Allah swt. Agar segala kemanfaatan alam semesta dan segala isinya dapat dinikmati oleh manusia dan makhluk lainnya. Kalau sebaliknya, pengurusan itu tidak baik artinya tidak sesuai dengan maksud yang telah ditetapkan Allah swt. Malapetaka sebagai akibatnya akan dirasakan oleh manusia juga oleh lingkungan hidupnya.

Untuk dapat melaksanakan tugasnya menjadi khalifah Allah swt Manusia diberi akal pikiran dan qalbu, yang tidak diberikan kepada makhluk lain. Dengan akal pikirannya manusia mampu mengamati alam semesta, menghasilkan dan mengembangkan ilmu, yang benihnya telah disemaikan Allah swt dengan mengajarkan nama-nama benda kepada manusia.

Manusia yang mempunyai kedudukan sebagai khalifah bertugas memakmurkan bumi ini dan segala isinya. Memakmurkan bumi artinya menyejahterakan kehidupan di dunia ini. Untuk itu manusia wajib bekerja, beramal shaleh, serta menjaga keseimbangan alam dan bumi yang didiaminya, sesuai dengan tuntunan yang diberikan oleh Allah swt melalui agama Islam. Alam semesta telah diberikan oleh Allah swt sebagai amanah untuk dikelola, karena hanya manusia yang diberi tanggungjawab memegang amanah Allah swt.

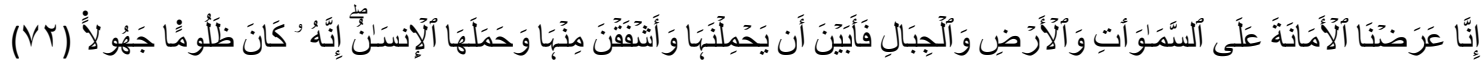
"Sesungguhnya Kami telah mengemukakan amanat [1] kepada langit, bumi dan gunung-gunung, maka semuanya enggan untuk memikul amanat itu dan mereka khawatir akan mengkhianatinya, dan dipikullah amanat itu oleh manusia. Sesungguhnya manusia itu amat zalim dan amat bodoh," (QS. Al-Ahzab [33]: 72). ${ }^{28}$

\section{TUGAS MANUSIA SEBAGAI KHALIFATULLAH}

\footnotetext{
${ }^{28}$ Mohammad Daud Ali, Pendidikan Agama Islam, (Jakarta: PT Raja Grafindo Persada, 2013),15-16.
} 
Dalam berbagai literatur yang membahas mengenai kedudukan manusia dalam alam semesta ini selalu dihubungkan dengan konsep kekhalifahan dan konsep ibadah. Menurut Quraish shihab dalam bukunya Membumikan Al-Quran misalnya, telah membahas masalah kekhalifahan ini. Menurut hasil penelitian beliau, bahwa di dalam al-Quran terdapat kata khalifah dalam bentuk tunggal sebanyak dua kali, yaitu dalam surat al-Baqarah ayat 30 dan Shad ayat 26; dan dalam bentuk plural (jamak), yaitu khala'if dan khulafa' yang masing-masing diulang sebanyak empat kali dan tiga kali. (Lihat Q.S. al-An'am, 6:165; Yunus, 10;14,73; Fathir, 35:39; al-A'raf,7:69,74 dan alNaml,27:62).

Keseluruhan kata tersebut menurutnya berakar pada kata khulafa' yang pada mulanya berarti "di belakang". Dari sini, kata khalifah menurutnya seringkali diartikan sebagai "pengganti" (karena yang menggantikan selalu berada atau datang belakang, sesudah yang digantikannya).

Gambar 1.7

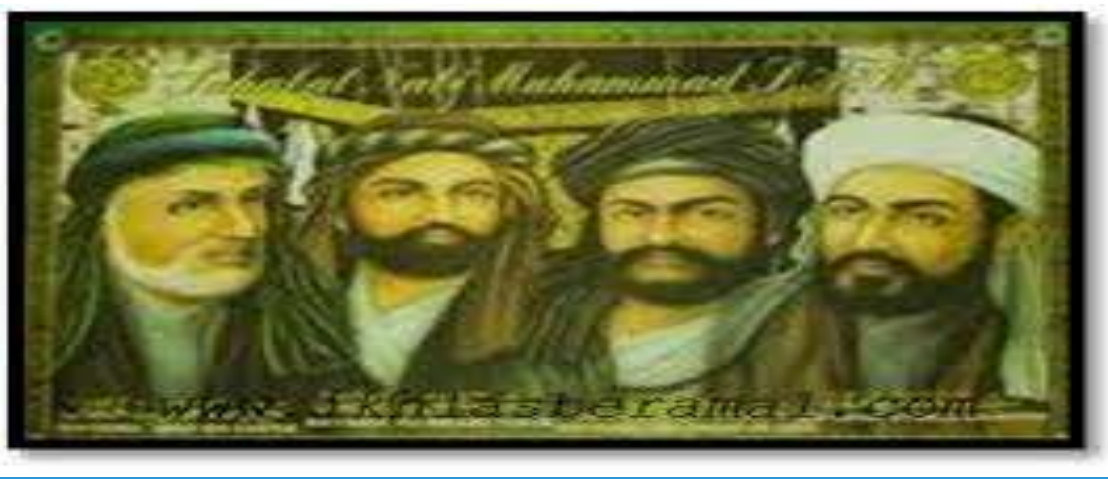

Nasabrya bersambung kepada Nabí Isma'il A.S

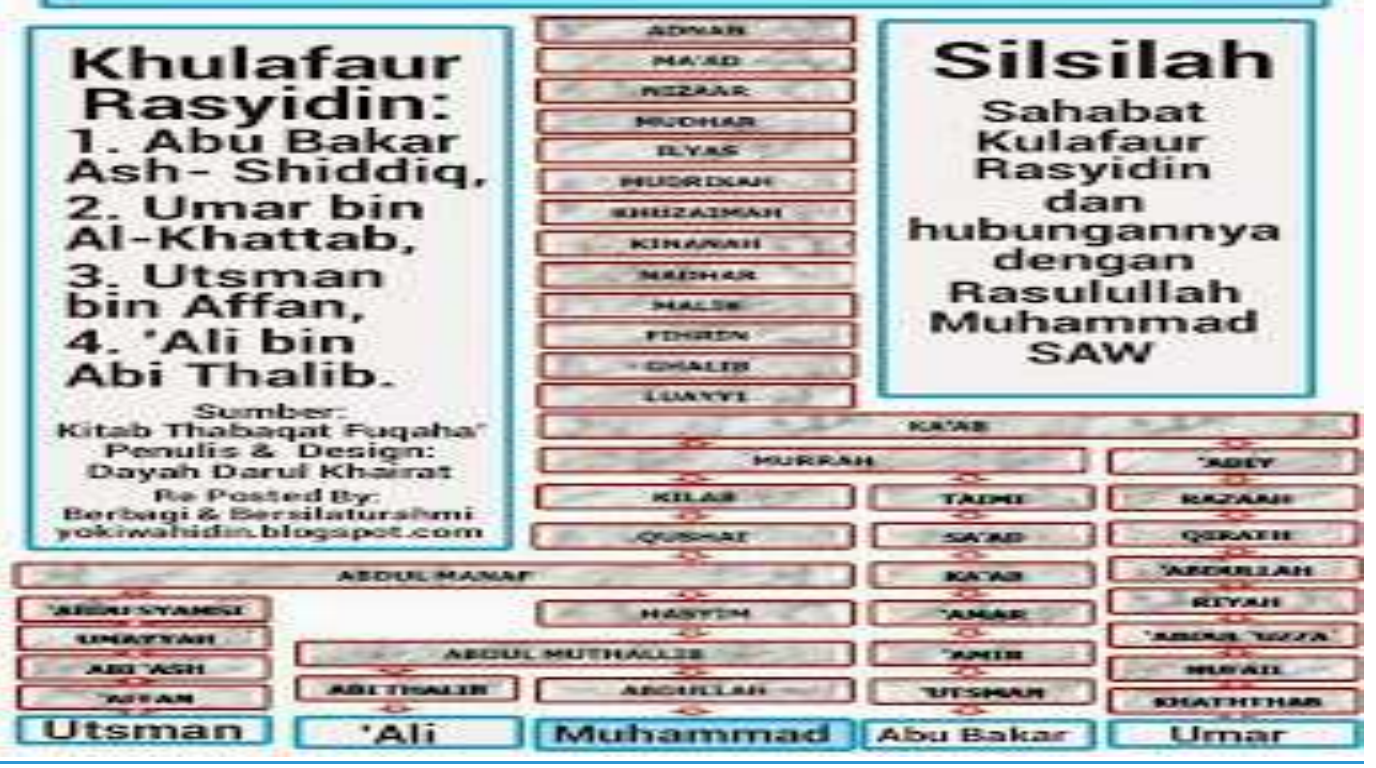


Dalam uraian selanjutnya Quraish Shihab menguraikan segi penggunaan dari istilahistilah tersebut, dengan mengacu kepada ayat yang artinya; "Dan Daud membunuh Jalut, Allah memberinya kekuasaan/kerajaan dan hikmah serta mengajarkannya apa yang dia kehendaki". Quraish shihab mengatakan bahwa kekhalifahan yang dianugrahkan kepada Daud as. bertalian dengan kekuasaan untuk mengolah wilayah tertentu. Hal ini diperolehnya berkat anugerah Ilahi yang mengajarkan kepadanya al-Hikmah dan ilmu pengetahuan. Disebutnya istilah kekhalifahan yang dikaitkan dengan upaya Tuhan yang mengajarkan al-hikmah dan ilmu pengetahuaan disebutkan itu memberi petunjuk yang jelas tentang adanya kaitan yang erat antara pelaksanaan fungsi kekhalifahaan dengan pendidikan dan pengajaran. Yaitu bahwa untuk melaksanakan funsi kekhalifahan itu, seseorang perlu dibekali pendidikan. ${ }^{29}$

Masih menurut pendapat Quraish Shihab, bahwa makna "pengolahan wilayah tertentu" atau katakanlah bahwa pengelolaan wilayah tersebut berkaitan dengan kekuasaan politik, dipahami pula dengan ayat-ayat yang menggunakan bentuk khulafa'. Ini berbeda dengan kata khalaif yang tidak mengesankan adanya kekuasaan semacam itu, sehingga pada akhirnya kita dapat berkata bahwa sejumlah orang yang tidak memiliki kekuasaan politik dinamai al-Quran khalaif, tanpa menggunakan bentuk mufrad, tunggal (khalifah). Tidak digunakan bentuk tunggal untuk makna tersebut orang tidak dapat terlaksana tanpa bantuan orang lain, berbeda dengan khalifah yang bermakna penguasa dalam bidang politik itu. Hal ini dapat terwujud dalam diri pribadi seseorang atau diwujudkan dalam bentuk otoriter atau dictator. ${ }^{30}$

Selanjutnya jika diamati dengan seksama, nampak bahwa istilah khalifah dalam bentuk mufrad (tunggal) yang berarti penguasa politik hanya digunakan untuk nabi-nabi, yang dalam hal ini Adam As. Dan tidak digunakan untuk manusia pada umumnya. Sedangkan untuk manusia biasa digunakan istilah khala'if yang di dalamnya mempunyai arti yang lebih luas, yaitu bukan hanya sebagai penguasa politik tapi juga penguasa dalam berbagai bidang kehidupan. Dalam hubungan dengan pembicaraan dengan kedudukan manusia dalam alam ini, nampaknya lebih cocok digunakan istilah khala'if dari pada kata khalifah. Namun demikian yang terjadi dalam penggunaan sehari-hari adalah bahwa manusia sebagai khalifah di muka bumi ini. Pendapat yang demikian memang tidak ada salahnya, karena dalam istilah khala'if sudah terkandung makna istilah khalifah. Sebagai seorang khalifah ia berfungsi menggantikan orang lain, menggantikan kedudukannya, kepemimpinannya atau kekuasaannya.

Untuk lebih menegaskan fungsi kekhalifahan manusia di alam ini, dapat dilihat misalnya ayat-ayat di bawah ini.

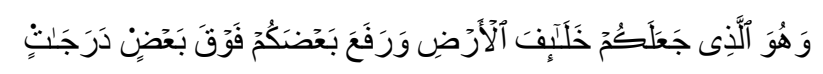

\footnotetext{
${ }^{29}$ Abbudin Nata, Filsafat Pendidikan Islam, (Ciputat: Logos Wacana Ilmu, 1997), 36.

${ }^{30}$ Ibid., 37.
} 
"Dan Dialah yang menjadikan kamu penguasa-penguasa di bumi dan Dia meninggikan sebahagian kamu atas sebahagian [yang lain] beberapa derajat, ......" (QS. Al-An'am $6: 165$ ).

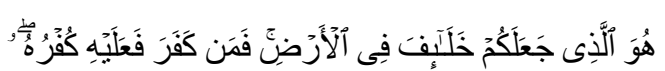

"Dia-lah yang menjadikan kamu khalifah-khalifah di muka bumi. Barangsiapa yang kafir, maka [akibat] kekafirannya menimpa dirinya sendiri. ......" (QS. Fathir 35 : 39).

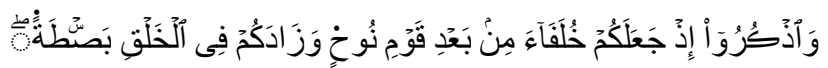

“... Dan ingatlah oleh kamu sekalian di waktu Allah menjadikan kamu sebagai penggantipengganti [yang berkuasa] sesudah lenyapnya kaum Nuh, dan Tuhan telah melebihkan kekuatan tubuh dan perawakanmu [daripada kaum Nuh itu]...." (QS. Al-A'raf, 7:69).

Ayat-ayat tersebut disamping menjelaskan kedudukan manusia di alam raya ini sebagai khalifah dalam arti yang luas juga memberikan isyarat tentang perlunya sikap moral atau etik yang harus ditegakkan dalam melaksanakan fungsi kekhalifahannya itu. ${ }^{31}$ Quraish Shihab, misalnya mengatakna bahwa hubungan manusia dengan alam atau hubungan manusia dengan sesamanya, bukan merupakan hubungan antara penakluk dengan yang ditaklukkan, atau antara tuan dengan hamba, tetapi hubungan kebersamaan dalam ketundukkan kepada Allah swt. Karena kalaupun manusia mampu mengelola (menguasai), namun hal tersebut bukan akibat yang dimilikinya, tetapi akibat Tuhan menundukanya untuk manusia.

Hal ini sejalan pula dengan apa yang dikemukakan Abu Musa al-Asya'arie Menurutnya bahwa tugas seorang khalifah adalah sebagai pengganti yang memegang kepemimpinan dan kekuasaaan, pada dasarnya mengandung implikasi moral karena kepemimpinan dan kekuasaan yang dimiliki khalifah dapat disalahgunakan untuk kepentingan mengejar hawa nafsunya, atau sebaliknya juga dapat dipakai untuk kepentingan menciptakan kesejahteraan hidup bersama.

Oleh karena itu, kepemimpinan dan kekuasaan manusia harus tetap diletakkan dalam kerangka eksistensi manusia yang bersifat sementara, sehingga dapat dihindari kecenderungan pemutlakan kepemimpinan atau kekuasaan, yang akibatnya dapat merusak tatanan dan harmoni kehidupan.

Selain itu kekuasaan khalifah pada dasarnya tidaklah bersifat mutlak, karena kekuasaannya dibatasi oleh pemberi mandat kekhalifahan, yaitu Allah swt. Dan sebagai pemegang mandat Allah swt, seorang khalifah tidak diperbolehkan melawan hukum-hukum yang ditetapkan.

Selanjutnya terdapat pula persyaratan yang bersifat teknis dan keterampilan yang harus dimiliki oleh seseorang yang menjadi khalifah. Hal ini dapat dilihat dari syarat yang terkandung dalam surat al-Baqarah ayat 30 dan 31. Pada ayat-ayat tersebut dijelaskan bahwa Nabi Adam as setelah diangkat sebagai khalifah di muka bumi ia kemudian diberikan pengajaran. Ini

\footnotetext{
${ }^{31}$ Abbudin Nata, Filsafat Pendidikan Islam, (Ciputat: Logos Wacana Ilmu, 1997), 37-38.
} 
mengisyaratkan bahwa seorang khalifah perlu memiliki pengetahuan, ketrampilan, mental yang dewasa, serta pendidikan pada umumnya. ${ }^{32}$

Kemampuan lebih yang dimiliki Nabi Adam as yang digambarkan dengan kemampuannya mengemukakan nama-nama tersebut di hadapan malaikat, yang keseluruhannya dapat diartikan sebagai kemampuan yang bersifat konseptual, justru menjadi salah satu modal yang melandasi kedudukan nabi Adam as. Sebagai khalifah. Dengan kata lain, karena Nabi Adam as. Memiliki kemampuan yang bersifat konseptual yang dihasilkan melalui pendidikan itulah yang menjadi kunci kesuksesannya sebagai khalifah Allah swt. Ini artinya bahwa sebagi seorang khalifah perlu memiliki pendidikan yang cukup.

Sejalan dengan uraian tersebut di atas, Hasan Langgulung mengatakan bahwa manusia yang di anggap sebagai khalifah Allah tidak dapat memegang tanggungjawab sebagai khalifah kecuali kalau ia diperlengkapi dengan potensi-potensi yang membolehkanya berbuat demikian. Lebih lanjut Hasan Langgulung mengatakan bahwa al-Quran menyatakan adanya berberapa ciri yang dimiliki manusia untuk mampu melaksanakan fungsi kekhalifahannya itu.

Ciri-ciri tersebut antara lain dari segi fitrahnya yang baik dari sejak awal. la tidak mewarisi dosa karena Adam as. meninggalkan surga. Ciri lainnya adalah yang bersifat fisik. AlQuran mengakui kebutuhan-kebutuhan biological manusia yang menuntut pemuasan. Hal ini pada tahap selanjutnya memerlukan penjelasan tentang syarat-syarat yang menyebabkan kebutuhan biological ini mungkin dapat berdampingan dengan fitrah yang baik itu keduanya tanpa menimbulkan masalah. Kedua hal inilah yang mendukung tugas kekhalifahan manusia di muka bumi. ${ }^{33}$

Kedudukan lainnya dari manusia di alam ini yang sering diangkat oleh para pakar adalah sebagai hamba yang harus beribadah kepada Allah swt. Hal ini biasanya didasarkan pada petunjuk ayat yang artinya: tidaklah aku menciptakan jin dan manusia kecuali agar mereka menyembah (ibadah) kepada-Ku. (Q.S al-Dzariyat, 51:56). Pengertian ibadah dalam ayat ini adalah merupakan pengembangan fitrah itu setinggi-tingginya, yang oleh aliran kemanusiaan disebut perwujudan diri self actualization. Penjelasan ini erat kaitannya dengan pelaksanaan fungsi kekhalifahan sebagainan telah di uraikan di atas. Dengan ungkapan lain bahwa pelaksanaan ibadah itu pada hakekatnya adalah dalam rangka melaksanakan fungsi kekhalifahan sebagaimana telah disebutkan di atas.

Sementara itu Musa al-Asy'arie mengatakan bahwa essensi 'abd adalah ketaatan, ketundukan, dan kepatuhan yang semuanya itu hanya layak diberikan kepada Allah swt.

\footnotetext{
${ }^{32}$ Abbudin Nata, Filsafat Pendidikan Islam, (Ciputat: Logos Wacana Ilmu, 1997), 38-39.

${ }^{33}$ Abbudin Nata, Filsafat Pendidikan Islam, (Ciputat: Logos Wacana Ilmu, 1997), 39-40.
} 
Ketundukan dan ketaatan pada kodrat alamiyah yang senantiasa berlaku baginya. la terikat oleh hukum-hukum tuhan yang menjadi kodrat pada setiap ciptaan-Nya, manusia menjadi bagian dari ciptaan-Nya, ia bergantung dengan seamanya, hidup dan mati menjadi bagiannya yang pasti. Akan tetapi manusia tidak terikat sepenuhnya oleh hukum-hukum alamiah saja, karena sebagai makhluk yang dilebihkan daripada alam ciptaan Tuhan lainnya, manusia diberikan kemampuan akalnya, sehingga mampu mengolah potensi alam menjadi sesuatu yang baru yang diperlukan bagi kehidupannya. Dalam perkembangannya, manusia pun terikat oleh hukum-hukum dalam upaya mengembangkan dan mewujudkan pemikirannya.

Jika pengertian ibadah ini dihubungkan dengan pengertian khalifah sebagaimana diuraikan sebelumnya maka dapat diperoleh pemahamaan yaitu bahwa khalifah adalah pengganti yang memegang kepemimpinan dan kekuasaan dari yang digantikan, ia menjadi pemegang kepemimpinan dan kekuasaan yang ada. Sebagai seorang pemimpin dan penguasa, ia mempunyai wewenang untuk menentukan pilihan dan bebas untuk menggunakan akalnya, sedangkan 'abd adalah seorang yang telah kehilangan wewenang untuk menentukan pilihan dan kehilangan untuk berbuat. Esensi seorang khalifah adalah kebebasan dan kreativitas, sedangkan seorang 'abd adalah ketaatan dan kepatuhan. ${ }^{34}$

Allah swt menciptakan manusia tidak main-main, seperti dalam Firman-Nya yang terdapat pada Qs al-Mukminun ayat 115:

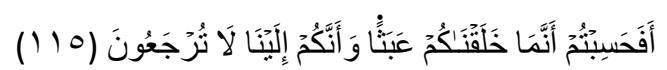

“Maka apakah kamu mengira, bahwa sesungguhnya Kami menciptakan kamu secara main-main [saja], dan bahwa kamu tidak akan dikembalikan kepada Kami?"

Oleh karenanya tidak layak manusia mengira bahwa hidupnya tanpa tanggung jawab, seperti disebut dalam Firman-Nya pada surat al-Qiyamah ayat 36:

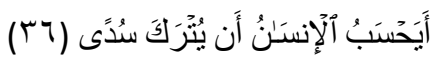
Artinya: "Apakah manusia mengira, bahwa ia akan dibiarkan begitu saja [tanpa pertanggungjawaban]?". ${ }^{35}$

Sebagaimana dikemukakan diatas, manusia memperoleh mandat "amanah" dari Allah swt menjadi Khalifah di Bumi, dengan tugas-tugas antara lain:

\section{Menempati Kawasan atau Wilayah Bumi}

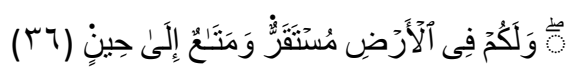

\footnotetext{
${ }^{34}$ Abbudin Nata, Filsafat Pendidikan Islam, (Ciputat: Logos Wacana Ilmu, 1997), 40-41.

${ }^{35}$ Muhammad Tholhah Hasan, Islam dan Masalah Sumber Daya Manusia, (Jakarta: Lantabora Press, 2003), 7980.
} 
“... dan bagi kamu ada tempat kediaman di bumi, dan kesenangan hidup sampai waktu yang ditentukan". (QS. Al-Baqarah [2]: 36).

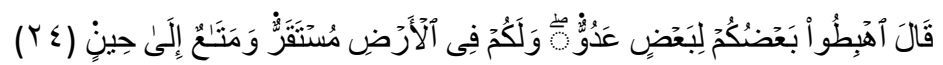

"Allah berfirman: "Turunlah kamu sekalian, sebahagian kamu menjadi musuh bagi sebahagian yang lain. Dan kamu mempunyai tempat kediaman dan kesenangan [tempat mencari kehidupan] di muka bumi sampai waktu yang telah ditentukan". (QS. Al-A'raaf [7]: $24)^{36}$

\section{Memanfaatkan Kekayaan dan Sumber Daya Alam}

\section{Firman Allah swt dalam surat al-Nahl ayat 5}

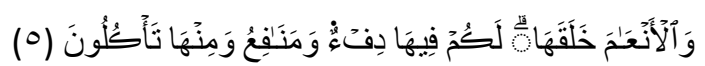
"Dan Dia telah menciptakan binatang ternak untuk kamu; padanya ada [bulu] yang menghangatkan dan berbagai-bagai manfa'at, dan sebagiannya kamu makan"

Firman Allah swt dalam surat al-Mukminun ayat 21

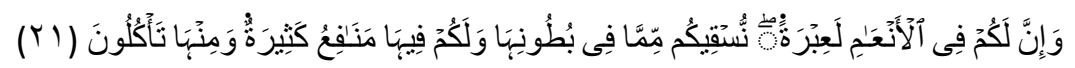
"dan sesungguhnya pada binatang-binatang ternak, benar-benar terdapat pelajaran yang penting bagi kamu, Kami memberi minum kamu dari air susu yang ada dalam perutnya, dan [juga] pada binatang-binatang ternak itu terdapat faedah yang banyak untuk kamu, dan sebagian darinya kamu makan".

\section{Firman Allah swt dalam surat Yasin ayat 72-73}

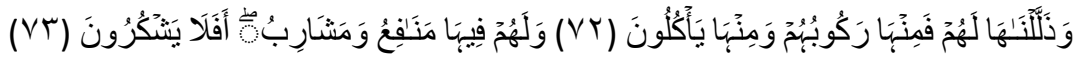

"Dan Kami tundukkan binatang-binatang itu untuk mereka, maka sebagiannya menjadi tunggangan mereka dan sebagiannya mereka makan. Dan mereka memperoleh padanya manfa'at-manfa'at dan minuman. Maka mengapakah mereka tidak bersyukur?”

\section{Firman Allah swt dalam surat al-Hadid ayat 25}

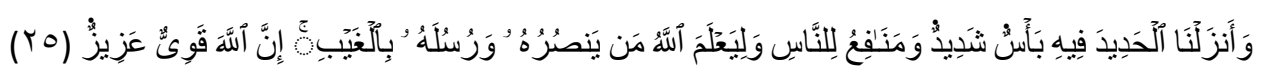
“... Dan Kami ciptakan besi yang padanya terdapat kekuatan yang hebat dan berbagai manfa'at bagi manusia, [supaya mereka mempergunakan besi itu] dan supaya Allah mengetahui siapa yang menolong [agama] Nya dan rasul-rasul-Nya padahal Allah tidak dilihatnya. Sesungguhnya Allah Maha Kuat lagi Maha Perkasa."

\footnotetext{
${ }^{36}$ Muhammad Tholhah Hasan, Islam dan Masalah Sumber Daya Manusia, (Jakarta: Lantabora Press, 2003), 8586.
} 
Juga diharapkan mampu mengambil pelajaran dari seluruh fenomena sosial dan natural (biofisik) dalam hubungan dengan tujuan religious maupun hubungannya dengan masalah social dan keilmuan "intifa' dan I'tibar". ${ }^{37}$ Masalah diatas terkandung dalam alQur'an diantaranya:

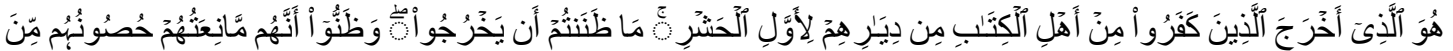

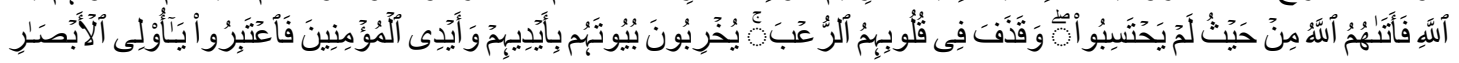

"Dia-lah yang mengeluarkan orang-orang kafir di antara ahli Kitab dari kampung-kampung mereka pada saat pengusiran kali yang pertama [2]. Kamu tiada menyangka, bahwa mereka akan keluar dan merekapun yakin, bahwa benteng-benteng mereka akan dapat mempertahankan mereka dari [siksaan] Allah; maka Allah mendatangkan kepada mereka [hukuman] dari arah yang tidak mereka sangka-sangka. Dan Allah mencampakkan ketakutan ke dalam hati mereka; mereka memusnahkan rumah-rumah mereka dengan tangan mereka sendiri dan tangan orang-orang yang beriman. Maka ambillah [kejadian itu] untuk menjadi pelajaran, hai orang-orang yang mempunyai pandangan". (QS. Al-Hasr [59]: 2)

Firman Allah swt dalam surat Yusuf ayat 111

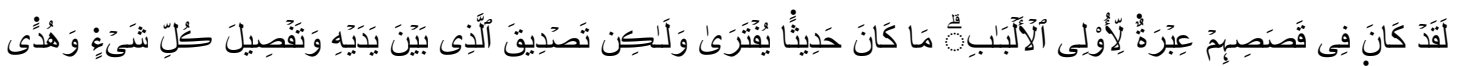

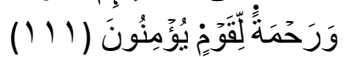
"Sesungguhnya pada kisah-kisah mereka itu terdapat pengajaran bagi orang-orang yang mempunyai akal. Al Qur'an itu bukanlah cerita yang dibuat-buat, akan tetapi membenarkan [kitab-kitab] yang sebelumnya dan menjelaskan segala sesuatu, dan sebagai petunjuk dan rahmat bagi kaum yang beriman."

Firman Allah swt dalam surat al-Nahl ayat 66

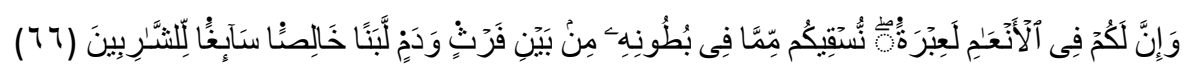

“Dan sesungguhnya pada binatang ternak itu benar-benar terdapat pelajaran bagi kamu. Kami memberimu minum daripada apa yang berada dalam perutnya [berupa] susu yang bersih antara tahi dan darah, yang mudah ditelan bagi orang-orang yang meminumnya."

Firman Allah swt dalam surat al-Mukminun ayat 21

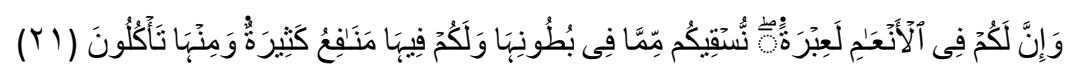

"Dan sesungguhnya pada binatang-binatang ternak, benar-benar terdapat pelajaran yang penting bagi kamu, Kami memberi minum kamu dari air susu yang ada dalam perutnya, dan

${ }^{37}$ Muhammad Tholhah Hasan, Islam dan Masalah Sumber Daya Manusia, (Jakarta: Lantabora Press, 2003), 8688. 
[juga] pada binatang-binatang ternak itu terdapat faedah yang banyak untuk kamu, dan sebagian darinya kamu makan".

Firman Allah swt dalam surat al-Nur ayat 44

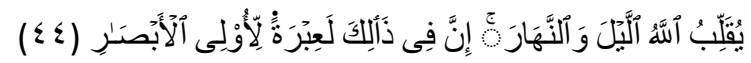
"Allah mempergantikan malam dan siang. Sesungguhnya pada yang demikian itu, terdapat pelajaran yang besar bagi orang-orang yang mempunyai penglihatan" ${ }^{38}$

3. Mewujudkan kesejahteraan hidup, kemaslahatan umum, dan menjaga kelestarian liingkungan hidup dari kemusnahan maupun kerusakan, seperti terkandung dalam:

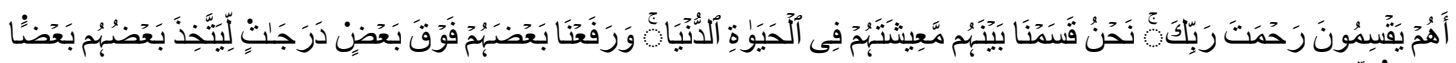

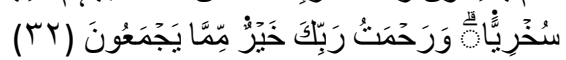
"Apakah mereka yang membagi-bagi rahmat Tuhanmu? Kami telah menentukan antara mereka penghidupan mereka dalam kehidupan dunia, dan Kami telah meninggikan sebahagian mereka atas sebahagian yang lain beberapa derajat, agar sebahagian mereka dapat mempergunakan sebahagian yang lain. Dan rahmat Tuhanmu lebih baik dari apa yang mereka kumpulkan.” (QS. Az-Zukhruf: 32)

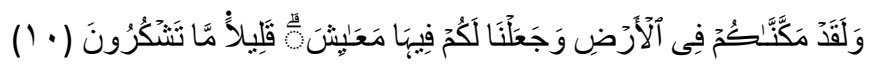
"Sesungguhnya Kami telah menempatkan kamu sekalian di muka bumi dan Kami adakan bagimu di muka bumi itu [sumber] penghidupan. Amat sedikitlah kamu bersyukur." (QS. Al$A^{\prime} \operatorname{raf}[7]:$ 10)

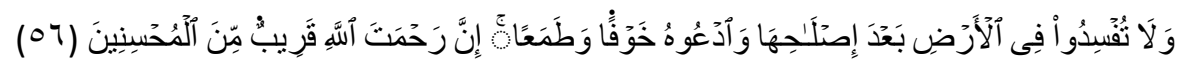
"Sesungguhnya Kami telah menempatkan kamu sekalian di muka bumi dan Kami adakan bagimu di muka bumi itu [sumber] penghidupan. Amat sedikitlah kamu bersyukur." (QS. AlAraf [7]: 56)

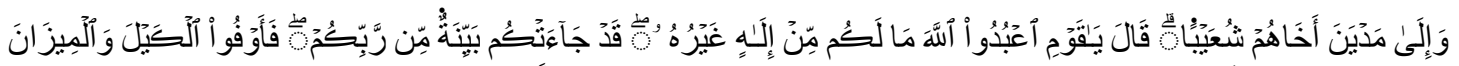

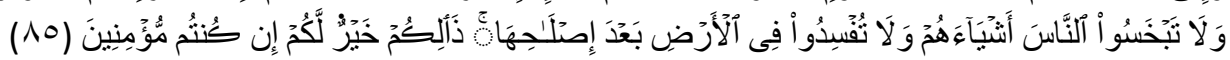
"Dan [Kami telah mengutus] kepada penduduk Mad-yan [1] saudara mereka, Syu'aib. la berkata: "Hai kaumku, sembahlah Allah, sekali-kali tidak ada Tuhan bagimu selain-Nya. Sesungguhnya telah datang kepadamu bukti yang nyata dari Tuhanmu. Maka sempurnakanlah takaran dan timbangan dan janganlah kamu kurangkan bagi manusia barang-barang takaran dan timbangannya, dan janganlah kamu membuat kerusakan di muka bumi sesudah Tuhan memperbaikinya. Yang demikian itu lebih baik bagimu jika betul-betul kamu orang-orang yang beriman". (QS. Al-A'raf: 85)

${ }^{38}$ Muhammad Tholhah Hasan, Islam dan Masalah Sumber Daya Manusia, (Jakarta: Lantabora Press, 2003), 8890. 


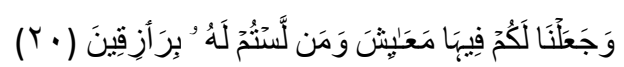

"Dan Kami telah menjadikan untukmu di bumi keperluan-keperluan hidup, dan [Kami menciptakan pula] makhluk-makhluk yang kamu sekali-kali bukan pemberi rezki kepadanya." (QS. Al-Hijr: 20)

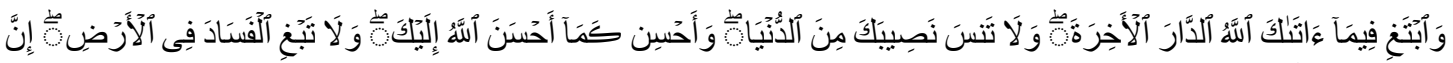

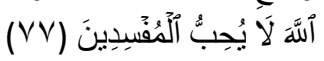
"Dan carilah pada apa yang telah dianugerahkan Allah kepadamu [kebahagiaan] negeri akhirat, dan janganlah kamu melupakan bahagianmu dari [keni'matan] duniawi dan berbuat baiklah [kepada orang lain] sebagaimana Allah telah berbuat baik kepadamu, dan janganlah kamu berbuat kerusakan di [muka] bumi. Sesungguhnya Allah tidak menyukai orang-orang yang berbuat kerusakan". (QS. Al-Qashas: 77)

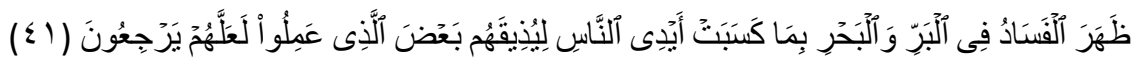

"Telah nampak kerusakan di darat dan di laut disebabkan karena perbuatan tangan manusia, supaya Allah merasakan kepada mereka sebahagian dari [akibat] perbuatan mereka, agar mereka kembali [ke jalan yang benar]". (QS. Ar-ruum [30]: 41)

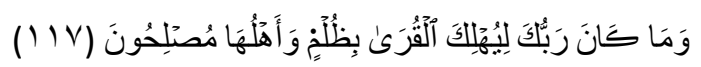

"Dan Tuhanmu sekali-kali tidak akan membinasakan negeri-negeri secara zalim, sedang penduduknya orang-orang yang berbuat kebaikan. (QS. Hud: 117)

Disamping ayat-ayat yang terkandung pada surat diatas juga terdapat ayat-ayat lainnya dalam surat lain. ${ }^{39}$

4. Mematuhi peraturan-peraturan Allah, demi kemaslahatan umat manusia, masalah ini antara lain terkandung dalam:

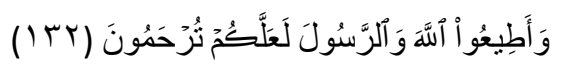

"Dan ta'atilah Allah dan Rasul, supaya kamu diberi rahmat." (QS. Ali-Imran [3]: 132)

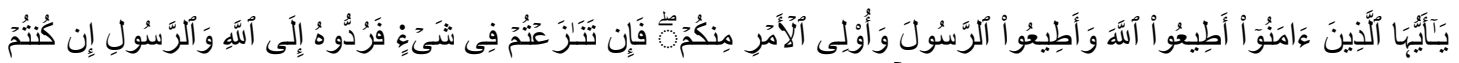

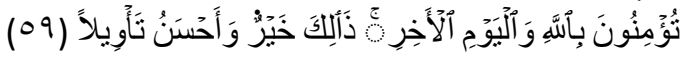
“Hai orang-orang yang beriman, ta'atilah Allah dan ta'atilah Rasul [Nya], dan ulil amri di antara kamu. Kemudian jika kamu berlainan pendapat tentang sesuatu, maka kembalikanlah ia kepada Allah [Al Qur'an] dan Rasul [sunnahnya], jika kamu benar-benar beriman kepada Allah dan hari kemudian. Yang demikian itu lebih utama [bagimu] dan lebih baik akibatnya". (QS. An-Nisa' [4]: 59)

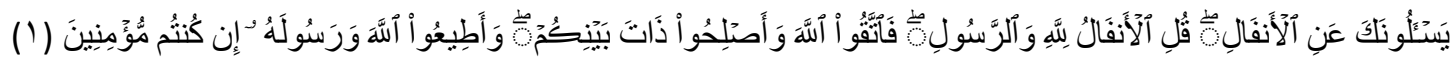
"Mereka menanyakan kepadamu tentang [pembagian] harta rampasan perang. Katakanlah: "Harta rampasan perang itu kepunyaan Allah dan Rasul[1], sebab itu bertakwalah kepada

${ }^{39}$ Muhammad Tholhah Hasan, Islam dan Masalah Sumber Daya Manusia, (Jakarta: Lantabora Press, 2003), 9194. 
Allah dan perbaikilah perhubungan di antara sesamamu, dan ta'atlah kepada Allah dan RasulNya jika kamu adalah orang-orang yang beriman". (QS. Al-Anfal [6]: 1)

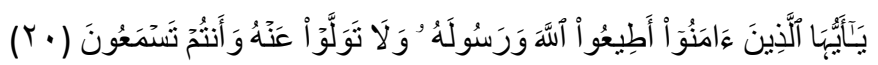

Artinya : "Hai orang-orang yang beriman, ta'atlah kepada Allah dan Rasul-Nya, dan janganlah kamu berpaling daripada-Nya, sedang kamu mendengar [perintah-perintah-Nya]," (QS. alAnfal [6]: 20)

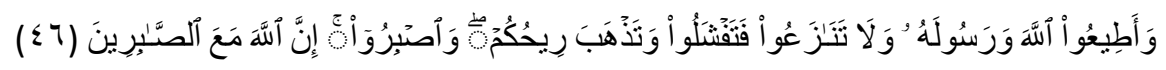

“Dan ta'atlah kepada Allah dan Rasul-Nya dan janganlah kamu berbantah-bantahan, yang menyebabkan kamu menjadi gentar dan hilang kekuatanmu dan bersabarlah. Sesungguhnya Allah beserta orang-orang yang sabar." (QS. Al-Anfal [6]: 56)

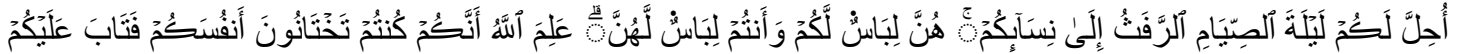

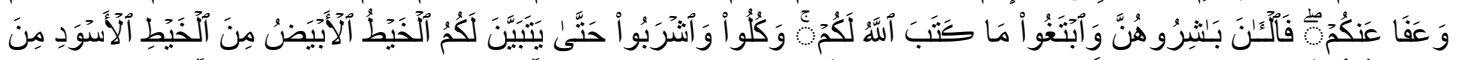

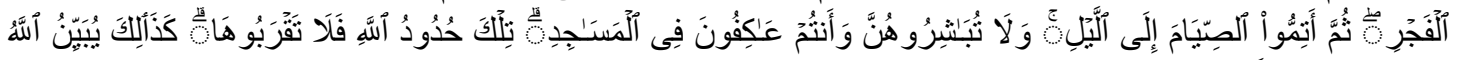

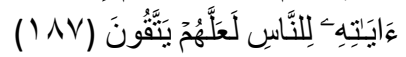
“Dihalalkan bagi kamu pada malam hari bulan Puasa bercampur dengan isteri-isteri kamu; mereka itu adalah pakaian bagimu, dan kamupun adalah pakaian bagi mereka. Allah mengetahui bahwasanya kamu tidak dapat menahan nafsumu, karena itu Allah mengampuni kamu dan memberi ma'af kepadamu. Maka sekarang campurilah mereka dan carilah apa yang telah ditetapkan Allah untukmu, dan makan minumlah hingga terang bagimu benang putih dari benang hitam, yaitu fajar. Kemudian sempurnakanlah puasa itu sampai [datang] malam, [tetapi] janganlah kamu campuri mereka itu, sedang kamu beri'tikaf [1] dalam masjid. Itulah larangan Allah, maka janganlah kamu mendekatinya. Demikianlah Allah menerangkan ayatayat-Nya kepada manusia, supaya mereka bertakwa." (QS. Al-Baqarah [2]: 187)

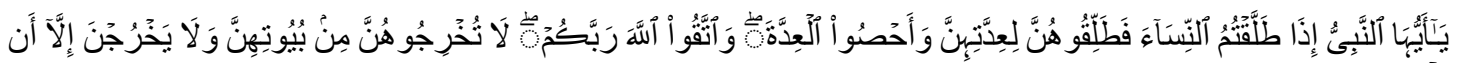

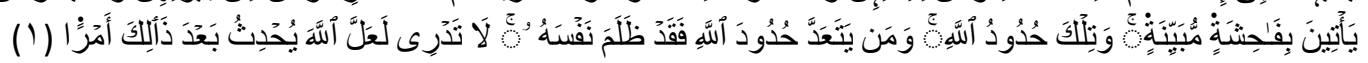
art"Hai Nabi, apabila kamu menceraikan isteri-isterimu maka hendaklah kamu ceraikan mereka pada waktu mereka dapat [menghadapi] idahnya [yang wajar] [1] dan hitunglah waktu idah itu serta bertakwalah kepada Allah Tuhanmu. Janganlah kamu keluarkan mereka dari rumah mereka dan janganlah mereka [diizinkan] keluar kecuali kalau mereka mengerjakan perbuatan keji yang terang [2]. Itulah hukum-hukum Allah dan barangsiapa yang melanggar hukum-hukum Allah, maka sesungguhnya dia telah berbuat zalim terhadap 
dirinya sendiri. Kamu tidak mengetahui barangkali Allah mengadakan sesudah itu suatu hal yang baru [3]." (QS. At-Thalaq : 1$)^{40}$

5. Mewujudkan kehidupan yang damai, saling menghormati, dan mengembangkan sikap ta'ruf antara sesaman manusia, dan menempatkan hubungan kemanusiaan sebagai hubungan keluarga besar, masalah ini terkandung antara lain dalam surat:

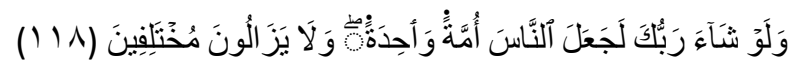
“Jika Tuhanmu menghendaki, tentu Dia menjadikan manusia umat yang satu, tetapi mereka senantiasa berselisih pendapat". (QS. Hud [11]: 118)

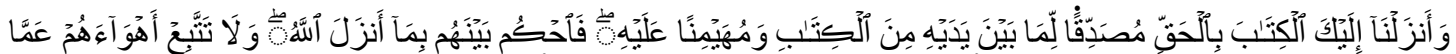

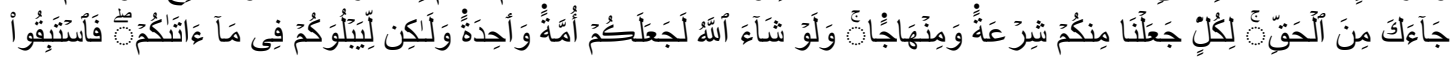

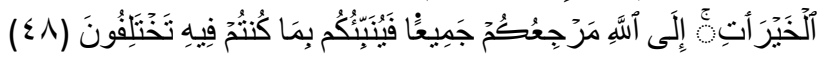
“Dan Kami telah turunkan kepadamu Al Qur’an dengan membawa kebenaran, membenarkan apa yang sebelumnya, yaitu kitab-kitab [yang diturunkan sebelumnya] dan batu ujian [3] terhadap kitab-kitab yang lain itu; maka putuskanlah perkara mereka menurut apa yang Allah turunkan dan janganlah kamu mengikuti hawa nafsu mereka dengan meninggalkan kebenaran yang telah datang kepadamu. Untuk tiap-tiap umat di antara kamu[4]. Kami berikan aturan dan jalan yang terang. Sekiranya Allah menghendaki, niscaya kamu dijadikanNya satu umat [saja], tetapi Allah hendak menguji kamu terhadap pemberian-Nya kepadamu, maka berlomba-lombalah berbuat kebajikan. Hanya kepada Allah-lah kembali kamu semuanya, lalu diberitahukan-Nya kepadamu apa yang telah kamu perselisihkan itu", (QS. AIMaidah [5]: 48) $)^{41}$

\section{BAB II}

${ }^{40}$ Muhammad Tholhah Hasan, Islam dan Masalah Sumber Daya Manusia, (Jakarta: Lantabora Press, 2003), 9498.

${ }^{41}$ Muhammad Tholhah Hasan, Islam dan Masalah Sumber Daya Manusia, (Jakarta: Lantabora Press, 2003), 98100. 


\section{AKHLAK TERPUJI}

\section{Capaian Perkuliahan}

1. Mampu memahami konsep Akhlak, membedakan akhlak terpuji dan akhlak tercela

2. Mampu menerapkan sifat kerja keras, tekun, dan lemah lembut dalam kehidupan sosial

3. Mampu meneladani Akhlak Rasulullah Muhammad saw terhadap keluarga, sahabat, maupun orang kafir

\section{A. Pengertian Akhlak Terpuji}

Akhlak berasal dari kata "akhlaq" yang merupakan jama' dari "khulqu" dari bahasa Arab yang artinya perangai, budi, tabiat dan adab. Akhlak itu terbagi dua yaitu Akhlak yang Mulia atau Akhlak yang Terpuji (Al-Akhlak Al-Mahmudah) dan Akhlak yang Buruk atau Akhlak yang Tercela (Al-Akhlak al-Madzmumah)

Gambar 1.7

(Paradog realitas remaja di lingkungan masyarakat)

\section{PERILAKU SEKSUAL REMAJA SCTV SMP dan SMU}

93,7\% Pernah ciuman, petting. oral seks

$62,7 \%$ Remaja suP tidak perawan

$21,2 \%$ Remaja suU pernah aborsi

$97 \%$ permah nonton film porno

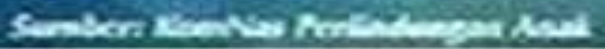




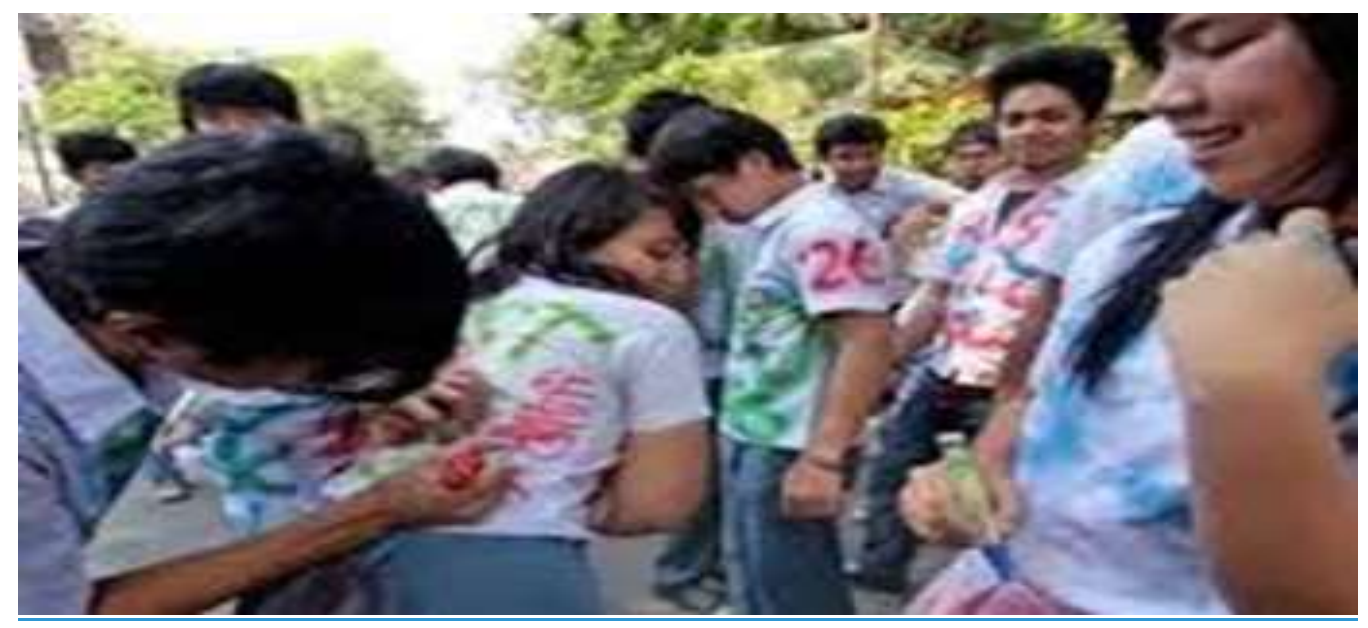

Akhlak yang mulia, menurut Imam Ghazali ada 4 macama perkara; yaitu bijaksana, memelihara diri dari sesuatu yang tidak baik, keberanian (menundukkan kekuatan hawa nafsu) dan bersifat adil. Jelasnya, ia merangkumi sifat-sifat seperti berbakti pada keluarga dan negara, hidup bermasyarakat dan bersilaturahim, berani mempertahankan agama, senantiasa bersyukur dan berterima kasih, sabar dan rida dengan kesengsaraan, berbicara benar dan sebagainya.

\section{B. Contoh Akhlak Terpuji}

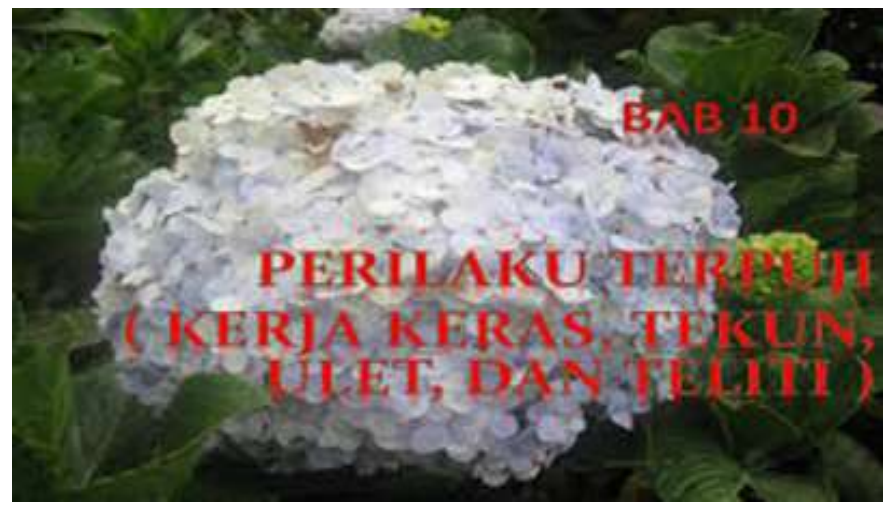

\section{Kerja Keras}

Kerja keras yaitu kegiatan melakukan sesuatu atau sesuatu yang dilakukan untuk mencari nafkah. Kerja yang dilakukan oleh manusia bertujuan untuk memperoleh makanan, pakaian, jaminan, dan kebahagiaan hidupnya. 
Kerja keras artinya melakukan sesuatu mencari nafkah dengan sungguh sungguh. Kerja keras untuk mencapai tujuan atau prestasi sebaiknya disertai dengan berserah diri (tawakal) kepada Allah swt. Baik untuk kepentingan dunia maupun akhirat. ${ }^{42}$

Firman Allah swt dalam al-Qur'an surat al-Qasas ayat 77

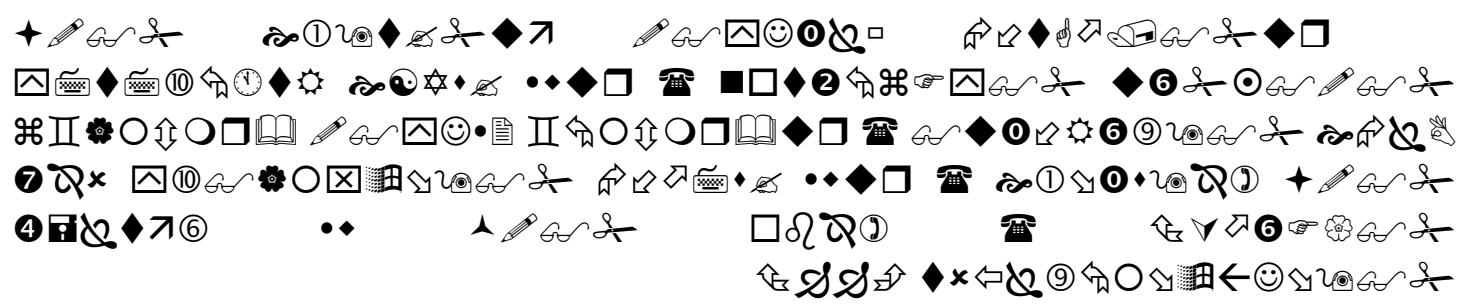

Artinya :

Dan carilah pada apa yang telah dianugerahkan Allah kepadamu (kebahagiaan) negeri akhirat, dan janganlah kamu melupakan bahagianmu dari (kenikmatan) duniawi dan berbuat baiklah (kepada orang lain) sebagaimana Allah telah berbuat baik, kepadamu, dan janganlah kamu berbuat kerusakan di (muka) bumi. Sesungguhnya Allah tidak menyukai orang-orang yang berbuat kerusakan. ${ }^{43}$ (Surat Al-Qasas $\{28\}: 77$ )

\section{a. Membiasakan perilaku kerja keras}

Perilaku kerja keras sudah dicontohkan oleh nabi muhammad. Beliau tidak hanya menghabiskan waktu untuk mengingat Allah saja, tetapi bekerja keras berdakwah, baik di Mekkah maupun Madinah. Berdasarkan hal tersebut, kita dapat meneladani bahwa kita diperintahkan oleh Allah dan Rasul-Nya untuk membiasakan perilaku bekerja keras, tidak boleh berangan-angan atau bergantung pada orang lain dengan meminta-minta.

Agar kita mendapatkan hasil kerja keras yang baik, yang perlu dilakukan adalah rajin dan bekerja keras agar berhasil dan dapat mencukupi kebutuhan hidup, meningkatkan kreativitas, berdoa dan bertawakkal kepada Allah, berlaku jujur, tidak mudah berputus asa dan bersabar jika mengalami kegagalan, selalu bersyukur atas rahmat Allah yang diterima. ${ }^{44}$

\footnotetext{
${ }^{42}$ Rachmat Hidayat, Budi Hendriyana, pendidikan agama Islam. (Jakarta : Pusat Kurikulum dan Perbukuan, Kementerian Pendidikan Nasional, 2011).Hal. 151

${ }^{43} \mathrm{Al}$ - Qur'an (Surat Al-Qasas $\{28\}$ : 77)

${ }^{44}$ Rachmat Hidayat, Budi Hendriyana, pendidikan agama Islamuntuk smp kelas VII (Jakarta : Pusat Kurikulum dan Perbukuan, Kementerian Pendidikan Nasional, 2011).Hal. 163
} 
Perintah untuk bekerja, berkarya, dan mencari rezeki yang halal dinyatakan dalam al-Qur'an dan Hadist

Firman Allah swt

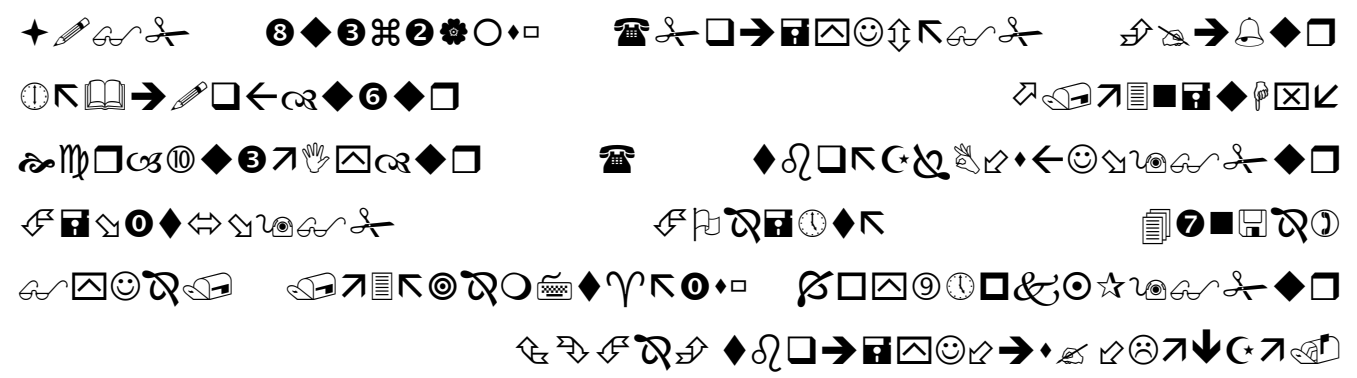

Artinya :

Dan Katakanlah: "Bekerjalah kamu, Maka Allah dan Rasul-Nya serta orang-orang mukmin akan melihat pekerjaanmu itu, dan kamu akan dikembalikan kepada (Allah) yang mengetahui akan yang ghaib dan yang nyata, lalu diberitakan-Nya kepada kamu apa yang telah kamu kerjakan. ${ }^{45}$

Hadis Nabi Muhammad SAW

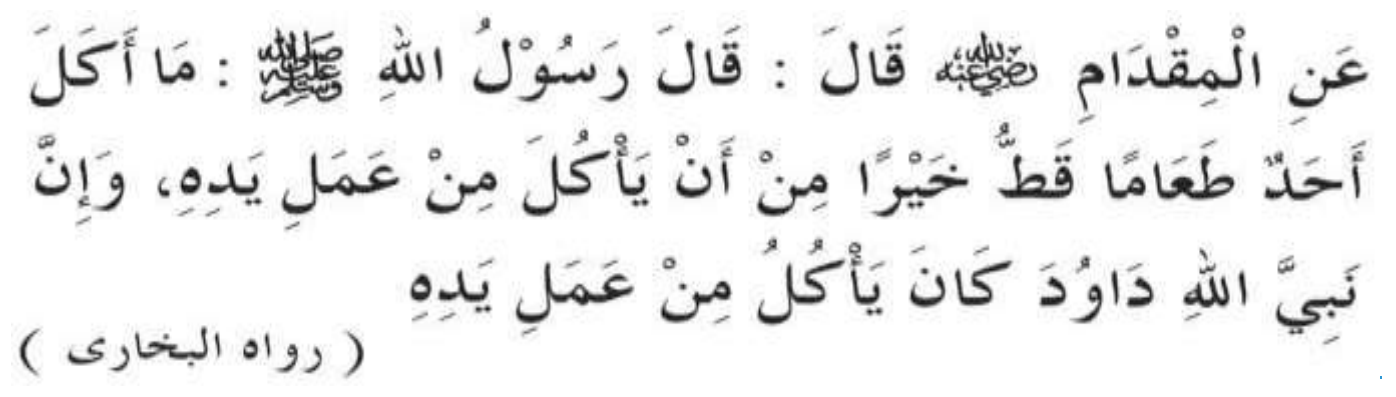

Artinya :

“Dari Miqdam r.a. berkata Nabi Muhammad saw. Bersabda : "Tidak satu pun makanan yang dimakan seseorang lebih baik dari pada kerja tangannya. Sesungguhnya Nabi Daud makan dari hasil kerja tangannya". (H.R. Bukhari)

Hadits di atas menjelaskan pada kita tentang keharusan bagi setiap individu membiasakan bekerja dengan tekun, tidak berpaku tangan mengharapkan balas kasihan orang lain. ${ }^{46}$

\footnotetext{
${ }^{45} \mathrm{Al}-$ qur'an (at - taubah $\{09\}: 105$

${ }^{46}$ Rachmat Hidayat, Budi Hendriyana ,pendidikan agama Islam VII (Jakarta : Pusat Kurikulum dan Perbukuan, Kementerian Pendidikan Nasional, 2011).Hal. 153
} 


\section{Perilaku Tekun}

Islam menyuruh setiap muslim untuk memiliki sikap pribadi yang tekun dan ulet bekerja. Sebaliknya, Islam sangat membenci orang yang malas dan berpangku tangan.

Tekun artinya mengarahkan pemikiran dan perasaan pada kegiatan yang dilakukan dengan sungguh-sungguh. Dalam belajar dan menuntut ilmu pun, kita harus menekuni apa yang sedang dipelajari. Dengan rajin belajar dan tekun, kita dapat meraih kesejahteraan hidup, baik di dunia maupun di akhirat. ${ }^{47}$

Firman Allah swt dalam al-Qur'an surat al-Mujadilah ayat 11

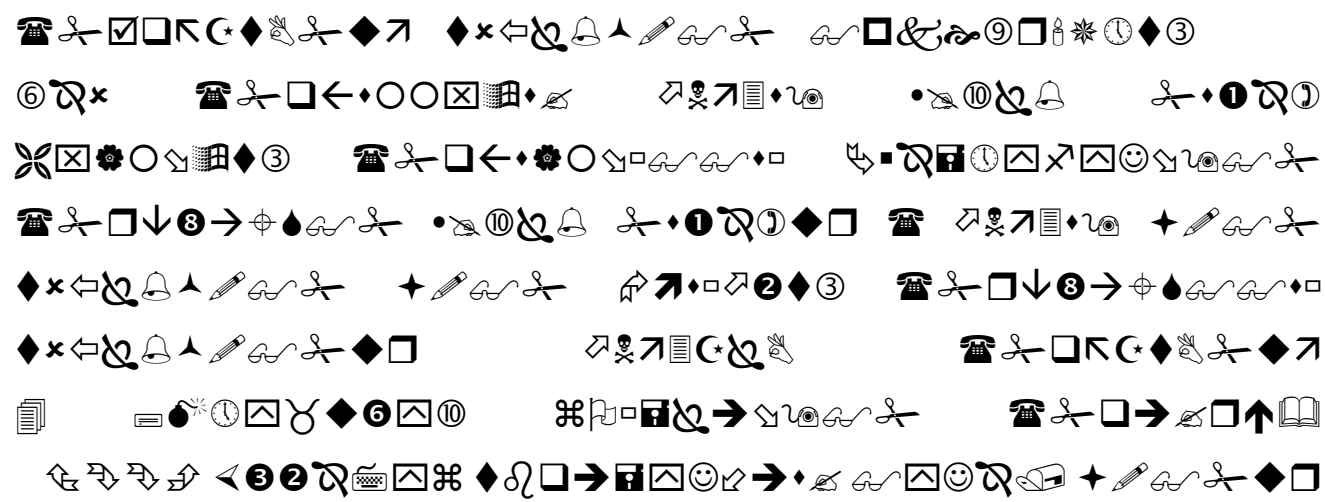
Artinya :

Hai orang-orang beriman apabila dikatakan kepadamu: "Berlapang-lapanglah dalam majlis", Maka lapangkanlah niscaya Allah akan memberi kelapangan untukmu. dan apabila dikatakan: "Berdirilah kamu", Maka berdirilah, niscaya Allah akan meninggikan orang-orang yang beriman di antaramu dan orang-orang yang diberi ilmu pengetahuan beberapa derajat. dan Allah Maha mengetahui apa yang kamu kerjakan. ${ }^{48}$

a. Membiasakan Perilaku Tekun

Sifat tekun dan ulet dalam semua pekerjaan akan menguntungkan dan membahagiakan, baik dalam urusan dunia maupun urusan akhirat. Segala yang ada di permukaan bumi ini adalah karunia Allah untuk manusia. Hanya manusia yang tekun dan ulet bekerja saja yang akan memperoleh manfaat dari karunia Allah swt. Begitu pula surga di akhirat nanti, hanya disediakan oleh Allah untuk orang-orang yang tekun atau rajin beramal dan beribadah waktu hidup di dunia. ${ }^{49}$

Membiasakan berperilaku tekun dan ulet dalam belajar adalah kewajiban utama pelajar, mahasiswa dan siapa saja yang sedang mencari ilmu. Dengan

\footnotetext{
${ }^{47}$ Ibid. 153

${ }^{48}$ Departemen Agama RI, al-Qur'an dan terjemahnya

${ }^{49}$ Amin, Ahmad, Etika (Ilmu Akhlak), (Terj), Farid M'aruf, dari judul asli al-Akhlak, Jakarta:Bulang Bintang, 1983. Hal. 41
} 
berperilaku tekun dan ulet, niscaya segala keinginan Insya Allah akan terwujud. Untuk itu, biasakanlah berperilaku tekun dan ulet Dalam setiap pekerjaan baik di rumah, di sekolah maupun di masyarakat.

\section{Sikap lemah lembut}

Menurut Imam Ghazali mendefinisikan sikap lemah lembut dengan terkalahkannya potensi kemarahan terhadap bimbingan akal. Menurut al Ghazali, tumbuhnya sifat lemah lembut dalam diri manusia dapat dimulakan dengan melatih diri menahan amarah. Allah swt berfirman dalam surat Ali Imran ayat 134.

Artinya :

(yaitu) orang-orang yang menafkahkan (hartanya), baik di waktu lapang maupun sempit, dan orang-orang yang menahan amarahnya dan mema'afkan (kesalahan) orang. Allah menyukai orang-orang yang berbuat kebajikan.(Qs. Ali Imran : 134) 50

Untuk memiliki karakter lemah lembut hal ini didapat dengan cara berusaha supaya menahan setiap amarah yang sedang bergejolak. Jika seseorang telah terbiasa dengan sikap seperti ini maka setiap kelembutannya akan menjadi akhlaknya, dan amarahnya tidak akan bergejolak. Seandainya bergejolak pun dia tidak akan kesulitan mengendalikannya. ${ }^{51}$

Terdapat sebagian orang yang beranggapan bahwa sifat lemah lembut adalah sikap menahan nafsu. Pendapat ini kurang tepat, karena nafsu yang ditahan jumlahnya sangat banyak, tidak hanya kemarahan saja. Menahan nafsu adalah akhlak yang paling utama dan harus dimiliki setiap manusia. Dengan menahan nafsu, seseorang akan banyak mendapatkan keutamaan-keutamaan, karena sikap itu dapat menjaga seseorang dari tuntunan agama. Sikap ini juga melindungi seseorang dari ketundukan terhadap hawa nafsu, menjauhkan dari perbuatan zalim, terlena sehingga melanggar batas-batas yang telah ditetapkan oleh agama.

\footnotetext{
${ }^{50}$ QS. Ali Imran $(3: 134)$

${ }^{51}$ Budi Hendriyana ,pendidikan agama Islam VII (Jakarta : Pusat Kurikulum dan Perbukuan, Kementerian Pendidikan Nasional, 2011).Hal. 155
} 
Sikap lemah lembut sangat berhubungan dengan sifat sabar. Dua sifat ini memang hampir sama, oleh karena itu kedua kata ini "al-Hilm wa al-Sabr" sering digunakan untuk menunnjuk satu makna yang sama, sebagaimana dalam firman Allah swt dalam surat Ali Imran ayat $186 .^{52}$

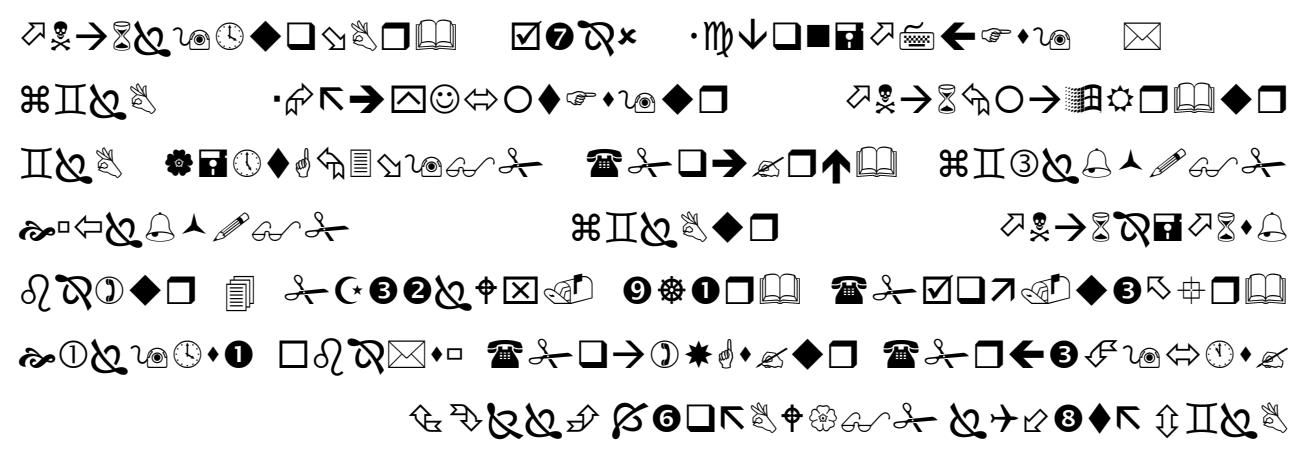

Kamu sungguh-sungguh akan diuji terhadap hartamu dan dirimu. dan (juga) kamu sungguh-sungguh akan mendengar dari orang-orang yang diberi kitab sebelum kamu dan dari orang-orang yang mempersekutukan Allah, gangguan yang banyak yang menyakitkan hati. jika kamu bersabar dan bertakwa, Maka Sesungguhnya yang demikian itu Termasuk urusan yang patut diutamakan. ${ }^{53}$

\section{Diantara Sifat Lemah Lembut Yang Dicontohkan Nabi Muhammad saw diantaranya sebagai berikut:}

1. Lembut terhadap istri/keluarga

Dalam banyak hadits yang menceritakan betapa Rasulullah saw sangat lemah lembut terhadap istri-istrinya. Rasul tidak pernah melotot, menaikkan nada suara dan marah kepada istrinya. Beliau biasa memanggil istri-istrinya dengan panggilan kesukaan dan panggilan yang indah. Seperti ya Humaira untuk memanggil Aisyah. Rasul juga adalah orang yang paling lembut dan banyak menemani istrinya yang sedang mengadu atau sakit. Banyak teladan Rasul yang bisa menjadi inspirasi kita dalam bersikap lemah lembut terhadap istri

2. Lembut terhadap anak-anak.

Rasulullah pernah mencium Hasan Ibna Ali Bin Abi Tahlib ra, sementara Al-Aqra' bin Habs At-Tamimi sedang duduk di sisi beliau. Maka Al-Aqra' berkata, 'Aku memiliki 10 anak, namun tidak ada satupun dari mereka yang ku cium.' Kemudian Rasulullah

\footnotetext{
${ }^{52}$ QS. Ali Imran Ayat 186

${ }^{53}$ Ibid hal. 156
} 
memandangnya, lalu bersabda, 'Siapa yang tidak menyayangi, maka dia tidak akan disayangi.' (HR. Bukhari Muslim).

3. Lembut terhadap orang jahil/belum paham Islam

Ada seseorang yang berbicara di dalam shalatnya. Dia mengira, bahwa ketika sedang mengerjakan shalat diperbolehkan berbicara. Karena orang ini jahil (tidak mengetahui hukumnya) dan mukhthi' (keliru), maka shalatnya tidak batal. ${ }^{54}$ Dia telah melakukan sebuah kesalahan, namun tanpa maksud yang disengaja. Secara khusus, terdapat dalil yang menunjukkan perbuatan seperti ini. Yaitu hadits Mu'awiyah bin al Hakam as Sulami Radhiyallahu 'anhu, yang cukup panjang, tentang diharamkannya berbicara ketika seseorang sedang shalat.

Kisah ringkasnya, tatkala Mu'awiyah bin al Hakam as Sulami Radhiyallahu 'anhu shalat berjama'ah bersama Rasulullah, ia mendengar orang bersin. Dan orang yang bersin itu berkata "alhamdulillah," sehingga ia pun berkata (menjawab) "yarhamukallah". Akhirnya, orang-orang di sekitarnya memandang kepadanya. Dia pun berteriak. Lalu orang-orang di sekitarnya memukul-mukul paha mereka sebagai isyarat agar ia diam. Maka Mu'awiyah bin al Hakam as Sulami Radhiyallahu 'anhu pun terdiam. Begitu shalat usai, manusia yang paling berakhlak mulia (yaitu Rasulullah Shallallahu 'alaihi wa sallam ) memanggilnya. Akhirnya, Mu'awiyah bercerita tentang akhlak Rasulullah Shallallahu 'alaihi wa sallam ketika mengajarkan dan membimbingnya: Aku belum pernah melihat seorang pendidikpun sebelumnya maupun setelahnya yang lebih baik darinya. Demi Allah, ia tidak membentakku, tidak memukulku, dan tidak mencaciku.

4. Lembut terhadap orang yang meminta-minta

Suatu ketika ada seorang pengemis dari kalangan Anshar datang meminta-minta kepada Rasulullah saw. Lalu beliau bertanya kepada pengemis tersebut, "Apakah kamu mempunyai sesuatu di rumahmu?"

Pengemis itu menjawab, "Tentu, saya mempunyai pakaian yang biasa dipakai sehari-hari dan sebuah cangkir." Rasul lalu berkata, "Ambil dan serahkan ke saya!"

Pengemis itupun pulang mengambil satu-satunya cangkir miliknya dan kembali lagi pada Rasulullah saw. Rasulullah saw kemudian menawarkan cangkir itu kepada para sahabat, "Adakah di antara kalian yang ingin membeli ini?" Seorang sahabat menyahut, "Saya beli dengan satu dirham."Rasulullah saw menawarkannya kembali,

\footnotetext{
${ }^{54}$ Ahmad Amin, Etika (Ilmu Akhlak), (Terj), Farid M'aruf, dari judul asli al-Akhlak, Jakarta:Bulang Bintang, 1983. Hal. 45
} 
"Adakah di antara kalian yang ingin membayar lebih?" Lalu ada seorang sahabat yang sanggup membelinya dengan hargaa dua dirham Rasulullah saw memberikan dua dirham itu kepada si pengemis lalu menyuruhnya menggunakan uang itu untuk membeli makanan untuk keluarganya dan sisa uangnya digunakan untuk membeli kapak. $^{55}$

Rasullulah saw berkata, "Carilah kayu sebanyak mungkin dan juallah, selama dua minggu ini aku tidak ingin melihatmu." Sambil melepas kepergiannya Rasulullah saw pun memberinya uang untuk ongkos.

Dua minggu kemudian pengemis itu datang kembali menghadap Rasulullah saw sambil membawa uang sepuluh dirham hasil dari penjualan kayu. Kemudian Rasulullah saw menyuruhnya untuk membeli pakaian dan makanan untuk keluarganya seraya bersabda, "Hal ini lebih baik bagi kamu, karena meminta-meminta hanya akan membuat noda di wajahmu di akhirat nanti. Tidak layak bagi seseorang meminta-minta kecuali dalam tiga hal, fakir miskin yang benar-benar tidak mempunyai sesuatu, utang yang tidak bisa terbayar, dan penyakit yang membuat sesorang tidak bisa berusaha."

5. Lembut ketika amar ma'ruf nahi munkar

Dikisahkan dalam sebuah hadits bahwa suatu ketika Rasulullah saw sedang duduk-duduk bersama para sahabat radhiyallahu 'anhum di dalam masjid. Tiba-tiba muncul seorang 'Arab badui (kampung) masuk ke dalam masjid, kemudian kencing di dalamnya Maka, dengan serta merta bangkitlah para shahabat yang ada di dalam masjid, menghampirinya seraya menghardiknya dengan ucapan yang keras. Namun Rasulullah saw melarang mereka untuk menghardiknya dan memerintahkan untuk membiarkannya sampai orang tersebut menyelesaikan hajatnya. Kemudian setelah selesai, beliau shallallahu 'alaihi wa sallam meminta untuk diambilkan setimba air untuk dituangkan pada air kencing tersebut. (HR. Al Bukhari).

Kemudian beliau (Rasulullah saw) memanggil 'Arab badui tersebut dalam keadaan tidak marah ataupun mencela. Beliau shallallahu 'alaihi wa sallam pun menasehatinya dengan lemah lembut:

"Sesungguhnya masjid ini tidak pantas untuk membuang benda najis (seperti kencing atau kotor). Hanya saja masjid itu dibangun sebagai tempat untuk dzikir

\footnotetext{
${ }^{55}$ Ahmad Amin, Etika (Ilmu Akhlak), (Terj), Farid M'aruf, dari judul asli al-Akhlak, Jakarta:Bulang Bintang, 1983. Hal 48
} 
kepada Allah, shalat, dan membaca Al Qur'an."(HR.Muslim)

Melihat sikap Rasulullah saw yang demikian lembut dan halusnya dalam menasehati, timbullah rasa cinta dan simpati 'Arab badui tersebut kepada beliau shallallahu 'alaihi wa sallam. Maka ia pun berdoa: "Ya Allah, rahmatilah aku dan Muhammad, dan janganlah Engkau merahmati seorangpun bersama kami berdua." Mendengar doa tersebut Rasulullah shallallahu 'alaihi wa sallam tertawa dan berkata kepadanya:

"Kamu telah mempersempit sesuatu yang luas (rahmat Allah)." (HR. Al Bukhari dan yang lainnya)

6. Lembut terhadap orang kafir yang memusuhi kita

Kisah Nabi Muhammad saw ketika berdakwah ke Bani thaif, lalu beliau dicaci maki, dihina dan dilempari batu hingga kaki beliau berdarah-darah. Akhirnya beliau menjauh dari thaif dan berdoa

"Wahai Tuhanku, kepada Engkau aku adukan kelemahan tenagaku dan kekurangan daya-upayaku pada pandangan manusia. Wahai Tuhan yang Maha Rahim kepada sesiapa Engkau menyerahkan daku?Kepada musuh yang akan menerkamkan aku ataukah kepada keluarga yang engkau berikan kepadanya urusanku, tidak ada keberatan bagiku asal aku tetap dalam keredzaanMu. Dalam pada itu afiatMu lebih luas bagiku. Aku berlindung dengan cahaya mukaMu yang mulia yang menyinari segala langit dan menerangi segala yang gelap dan atasnyalah teratur segala urusan dunia dan akirat, dari Engkau menimpakan atas diriku kemarahanMu atau dari Engkau turun atasku azabMu kepada Engkaulah aku adukan hal ku sehingga Engkau redza. Tidak ada daya dan upaya melainkan dengan Engkau"

Demikianlah doa Rasulullah saw yang penuh dengan kepasrahan dan keikhlasan kepada Allah swt. Mendengar doa NabiNya ini, Allah swt menurunkan Jibril as yang langsung turun berhadapan dengan Rasulullah dan mengucapkan salam seraya berkata:" Allah swt mengetahui apa yang telah berlaku diantara kamu dan orangorang ini. Allah swt telah menyediakan malaikat di gunung-gunung, disini khusus untuk menjalankan apa saja perintah dan keinginan engkau wahai Rasulullah."

Sambil berkata demikian Jibrail menghadapkan malaikat penjaga gununggunung itu dimuka Baginda Rasul saw, kata Malaikat ini: "Wahai Rasulullah, saya bersiap sedia untuk menjalankan perintah Tuan. Kalau dikehendaki, saya sanggup menyebabkan gunung-gunung yang berada sebelah menyebelah di kota ini 
berbenturan sehingga penduduk-penduduk dikedua-dua belah mati tertindih. Kalau tidak, Tuan perintahkan apa saja hukuman yang selayaknya diterima oleh orang-orang ini."

Namun apa jawab Rasulullah mendengar janji-janji Malaikat itu yang sesuai dengan nafsu amarah ini? Nabi Muhammad saw. yang penuh dengan sifat rahim dan belas kasihan ini tidak mengiakan tetapi berkata:"Walaupun orang-orang ini tidak menerima Islam, saya harap dengan kehendak Allah swt, keturunan-keturunan mereka, pada satu masa nanti, akan menyembah Allah swt dan berbakti kepadaNya."

7. Lembut terhadap orang ahli maksiat

Hadits Abu Hurairah radhiyallahu 'anhu dan di dalamnya disebutkan:

"Ketika kami bersama Rasulullah saw tiba-tiba datang seseorang dan berkata: "Ya Rasulullah, celaka aku!"

Beliau berkata: "Ada apa dengan kamu?"

la berkata: "Aku menyetubuhi istriku, sedang aku dalam keadaan berpuasa." Beliau bersabda: "Apakah kamu memiliki budak yang bisa kamu merdekakan?" la menjawab: "Tidak."

Beliau bersabda: "Apakah kamu mampu berpuasa dua bulan berturut-turut?"

la menjawab: "Tidak." Beliau bersabda: "Apakah kamu bisa memberi makan enam puluh orang miskin?"

Sekali lagi ia menjawab: "Tidak."

Lalu diamlah Rasulullah saw dan ketika kami masih berada dalam keadaan hening (terdiam), didatangkanlah kepada Nabi saw sebuah keranjang yang berisi kurma. Beliau bersabda: "Mana orang yang bertanya tadi?" la berkata: "Saya." Beliau bersabda: "Ambillah ini dan sedekahkanlah dengannya." Orang tersebut berkata: "Apakah ada orang yang lebih fakir dariku ya Rasulullah? Demi Allah tidak ada di antara dua kampung ini rumah yang lebih fakir dari rumahku." Tertawalah Nabi shallallahu 'alaihi wasallam sampai nampak gigi taringnya, kemudian beliau bersabda: "Berikan ini kepada keluargamu."

8. Lembut terhadap kesabaran dan kesusahan

Pada tahun kesepuluh kenabian, istri Rasulullah, Khadijah binti Khuwailid, dan pamannya Abu Thalib, wafat. Berkata Ibnu Sa'd dalam Thabaqat-nya: Selisih waktu antara kematian Khadijah dan kematian Abu Thalib hanya satu bulan lima hari.

Khadijah sebagaimana dikatakan oleh Ibnu Hisyam adalah menteri kebenaran untuk Islam. Pada saat-saat Rasulullah menghadapi masalah-masalah berat, Khadijah 
(Istri Rasulullah) yang selalu menghibur dan membesarkan hatinya. Akan halnya Abu Thalib, dia telah memberikan dukungan kepada Rasulullah saw dalam menghadapi kaumnya.

Berkata Ibnu Hisyam: Setelah Abu Thalib meninggal, kaum kafir Quraisy bertambah leluasa melancarkan penyiksaan kepada Rasulullah saw, sampai orang awam Quraisy pun berani melemparkan kotoran ke atas kepala Rasulullah saw. Sehingga pernah beliau pulang ke rumah berlumuran tanah. Melihat ini, salah seorang putri beliau bangkit dan membersihkan kotoran dari atas kepalanya sambil menangis. Tetapi Rasulullah saw, berkata kepadanya, "Janganlah engkau menangis wahai anakku, sesungguhnya Allah akan menolong bapakmu."

9. Lembut terhadap Makhluk Allah swt

"Sesungguhnya Allah subhanahu wa ta'ala telah mewajibkan untuk berbuat baik atas segala sesuatu. Jika kalian membunuh, maka bunuhlah dengan cara yang baik. Jika kalian menyembelih, maka sembelihlah dengan cara yang baik. Dan hendaklah salah seorang dari kalian menajamkan pisaunya (ketika hendak menyembelih), dan menyenangkan sembelihannya." (HR. Muslim)

Itulah sepuluh sikap lemah lembut Rasul dalam kehidupan, jika kita melakukan nya karena mengikuti Rasul maka sikap lemah lembut kita bernilai ibadah. Setelah mengetahui ilmu dan dalil nya, tidak ada alasan bagi tiap muslim untuk tidak bersikap lemah lembut.

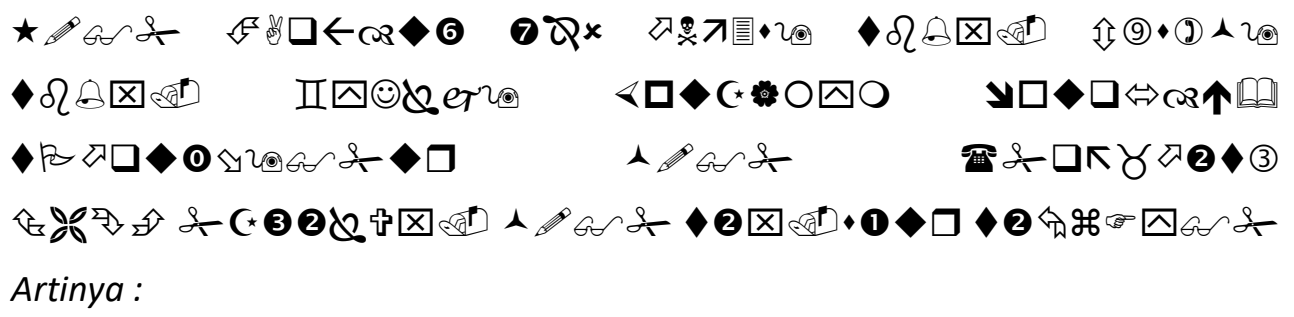
Artinya :

Sesungguhnya telah ada pada (diri) Rasulullah itu suri teladan yang baik bagimu (yaitu) bagi orang yang mengharap (rahmat) Allah dan (kedatangan) hari kiamat dan dia banyak menyebut Allah.". (QS: Al Ahzab [33] : 21). ${ }^{56}$

Namun, yang perlu diperhatikan bahwa sifat al-Rifq tidaklah menunjukkan kelemahan atau ketidaktegasan seseorang dalam berkata dan bertindak. Bahkan dalam sifat Ar-Rifq sendiri, sebenarnya telah mengandung sikap tegas dalam amar

\footnotetext{
${ }^{56}$ Departemen Agama RI, al-Qur'an dan terjemah
} 
ma'ruf nahi munkar (memerintahkan kepada kebaikan dan melarang dari kemungkaran). Dan tidaklah sikap tegas itu identik dengan sikap keras atau kasar. Dalam keadaan tertentu, Rasulullah saw bersikap tegas dan keras. Diantara contohnya:

a. Celaan beliau shallallahu 'alaihi wa sallam terhadap perbuatan memanjangkan shalat tanpa memperhatikan keadaan orang-orang yang berma'mum.(HR.AlBukhari)

b. Sikap keras beliau Rasulullah saw terhadap orang yang makan menggunakan tangan kiri ketika diperintah untuk makan menggunakan tangan kanan. (HR. Muslim)

c. Perkataan beliau "Celaka kamu" terhadap orang yang berlambat-lambat melaksanakan perintah beliau shallallahu 'alaihi wa sallam untuk menaiki unta. (HR. Al Bukhari)

d. Kerasnya sikap beliau shallallahu 'alaihi wa sallam terhadap orang (laki-laki) yang memakai cincin emas, setelah ia tahu bahwa perkara itu adalah perkara yang diharamkan.

(HR. Muslim)

Sifat Al-Rifq dalam menghadapi kerasnya problem kehidupan dan diantara pedoman dan kaidah syar'i yang harus dipegang teguh dalam menghadapi kerasnya problem (fitnah) dalam kehidupan adalah hendaknya kita menghadapinya dengan sifat al-Rifq (lemah lembut), al-Ta'anni (tidak tergesagesa), dan Al Hilm (santun). Maka hendaknya kita bersikap lemah lembut dan tenang/tidak tergesa-gesa dalam segala urusan dan janganlah menjadi orang yang mudah marah. Janganlah kita menjadi orang yang tidak mempunyai sifat al-rifq, karena dengan sifat al-rifq selamanya tidaklah akan membuat seseorang itu menyesal, baik dalam kehidupan dunia maupun akhirat. Tidaklah sifat al-rifq tersebut berada dalam suatu perkara kecuali akan memperindahnya.

\section{Kesetiaan}

Setia dapat diartikan teguh dan kukuh atas segala sesuatu yang diyakininya atau berpegang teguh atas ucapan dan pendiriannya. Agama Islam menganjurkan umatnya untuk bersikap setia atas suatu kebenaran dalam kehidupannya, baik kehidupan beragama, bermasyarakat, maupun berbangsa dan bernegara.

Sebagaimana sabda Rasulullah saw.: 
"Dari Abi Amrah bin Supyan bin Abdullah berkata: Aku telah berkata, wahai Rasulullah, katakanlah kepadaku suatu perkataan tentang Islam sehingga aku tidak bertanya kepada orang lain selain engkau. Rasulullah menjawab: Katakanlah, aku beriman kepada Allah kemudian teguhkanlah (setialah) atas pendirianmu." (H.R. Muslim).

\section{a. Ciri-ciri Sikap Orang Setia antara lain:}

1) Tidak mengingkari setiap ucapannya dan janji yang telah diperbuatnya, janji adalah utang maka kita wajib untuk tidak ingkar. Tunaikanlah setiap janji yang sudah kalian ucapkan, jangan sampai orang yang sudah di janjikan menunggu atau mengharap-harap janji anda. Dan juga tidak hanya setia kepada pacar saja, tetapi yang paling penting adalah setiap kepada Agama Allah swt, dan Rasul-Nya, itu yang harus kita jaga.

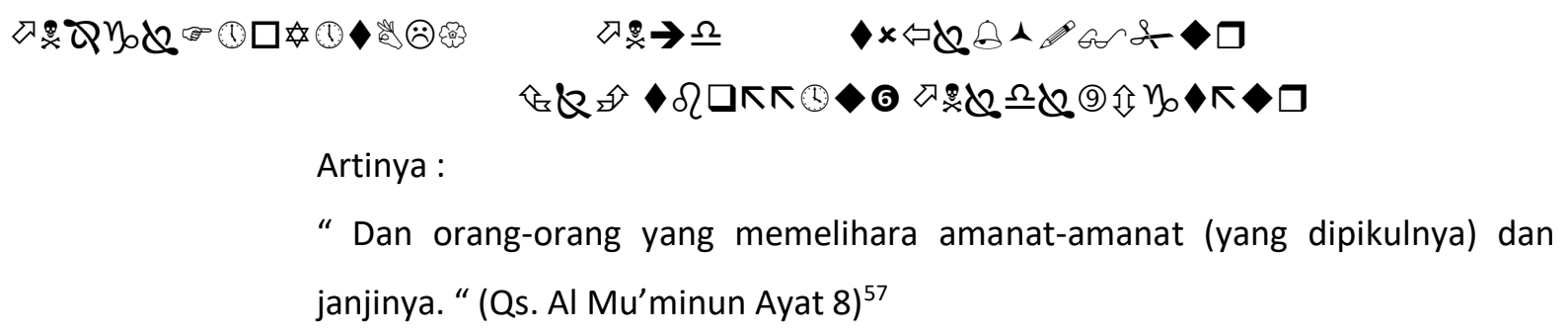

2. Tidak goyah terhadap godaan dan cobaan yang menimpanya dalam memegang teguh pendiriannya, orang yang setia biasanya sangat memegang teguh pendiriannya, apalagi kalau berpegang teguh kepada kebenaran apapun resiko yang akan dia hadapi kalau itu menyangkut kebenaran, harga mati baginya untuk selalu menjaga dan mempertahankannya.

3. Tidak melakukan suatu perbuatan yang dapat mengecewakan orang lain, perbuatan mengecewakan orang lain adalah salah satu perbuatan yang kurang terpuji, apalagi kalau orang itu mempercayakan suatu pekerjaan atau apapun yang dipercayakan kepada kita terus pekerjaan tidak sesuai dengan yang ia harapkan pasti akan sangat kecewa. Kalau kita mampu dan bisa kerjakanlah sebaik-baiknya.

4. Bersedia berkorban demi keteguhan pediriannya. Berpegang teguh itu baik apalagi bepegang teguh kepada keimanan dan agama Allah swt. Serta rasul-Nya, karena itu merupakan pegangan hidup kita. Supaya kita bisa selamat dunia dan

${ }^{57}$ QS. Al Mu'minun ayat 8 
akhirat, sebab kebahagiaan dunia itu hanya sementara, dan akhirat itu adalah kekal.

Gambar. 1.9

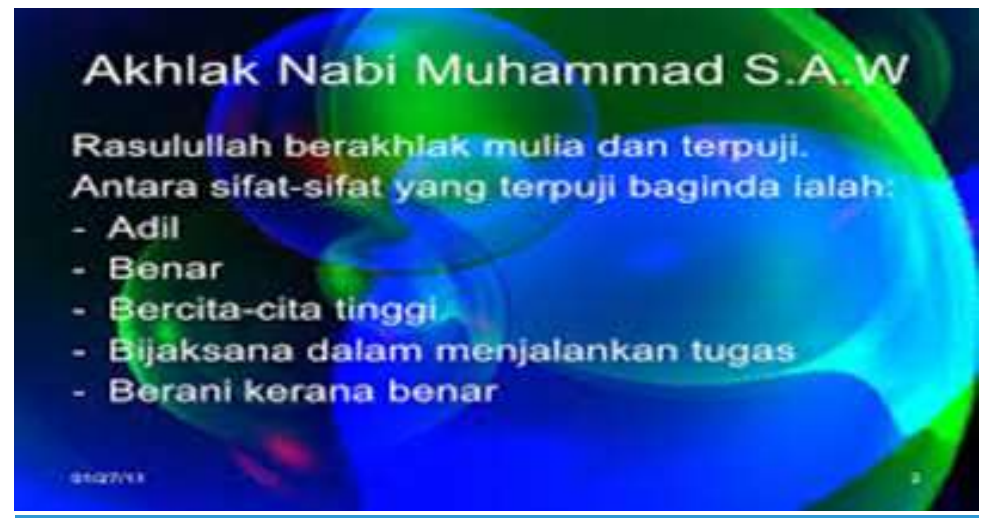

Kalau kita bersikap setia dalam kebenaran dan kebaikan, baik dalam pergaulan sehari-hari maupun terhadap pekerjaan yang baik, akan mendatangkan manfaat bagi diri kita dan orang lain, diantaranya:
a. Kita akan selalu dihormati dan dihargai oleh teman sepergaulan.
b. Akan dipercaya oleh orang lain, karena kesetiaan itu menunjukkan kejujuran.
c. Dapat menunjukkan suatu kesungguhan.
d. Terhindar dari konflik dan perselisihan.
e. Terhindar dari sikap yang dapat mengecewakan orang lain. 
BAB III

PRIBADI MULIA:

TAWADHU', TAAT, QANA'AH DAN IFFAH

\section{Capaian Perkuliahan}

1. Mampu memahami konsep Tawadhu', Taat, Qana'ah dan Iffah

2. Mampu mendeskripsikan sifat Qana'ah dalam kehidupan sosial

3. Mampu menerapkan sifat iffah dalam kehidupan pribadi dan sosial

Akhlak adalah perilaku lisan, perbuatan fisik, dan bahkan perbuatan diam juga termasuk dalam kategori akhlak. Akhlak terpuji adalah perilaku baik yang dimiliki seorang manusia. Akhlak terpuji merupakan bentuk implementasi dari keimanan manusia. Allah swt sangat menyukai hambaNya yang mempunyai akhlak terpuji. Akhlak terpuji dalam Islam disebut Akhlak Mahmudah. Bentuk dari akhlak terpuji antar lain: tawadhu', qana'ah, taat, dan sabar. ${ }^{58}$

\section{Tawadhu'}

\section{a. Pengertian Tawadhu'}

Tawadhu, artinya sikap rendah hati. Sikap ini merupakan sikap seseorang yang tidak ingin menonjolkan diri dengan sesuatu yang ada pada dirinya. Orang yang bersikap tawadhu' senantiasa ingat bahwa semua yang ada padanya adalah milik Allah swt. Oleh karena itu, orang yang bersikap tawadhu' tidak akan menghina orang lain dengan apapun yang diamanatkan Allah swt kepadanya. ${ }^{59}$

Cara berbicara orang yang bersikap tawadhu' senantiasa lembut dan merendah sekaligus memiliki rasa percaya diri yang kuat. la selalu berusaha berbuat yang terbaik tanpa ingin kebaikannya diketahui orang lain. la lebih suka menyampaikan kebaikan orang lain dari pada keburukannya. la tidak tersinggung atau marah saat orang lain menyampaikan keburukannya kepadanya. la selalu mengucap istighfar jika ada kritik kepadanya.

Sikap tawadhu' berbeda dengan sikap rendah diri. Rasa rendah diri berasal dari ketidakmampuan memandang dirinya dan orang lain dengan benar. Ketidak mampuan itu menyebabkan orang yang rendah diri salah menilai dirinya tidak baik, tidak mampu, tidak tampan atau tidak cantik, dan lebih pantas untuk suatu hal. Oleh karena itu, orang yang salah menilai diri cenderung merasa minder, tidak mampu, tidak percaya diri. Selain berbeda dengan rendah diri, sikap tawadhu' merupakan kebalikan dari sikap sombong.

\footnotetext{
${ }^{58}$ Abuddin Nata, Akhlak Tasawuf, (Jakarta: Rajawali Pers, 2010), hlm. 24.

${ }^{59}$ Supiana dan Karman, Materi Pendidikan Agama Islam (Bandung: PT Remaja Roda Karya,2004), hlm. 231.
} 
Orang Islam itu tawadlu' tanpa menghinakan dirinya, dan tawadlu' adalah akhlak dan sifatnya mulia. Serta sombong itu bukan sifatnya orang muslim, karena ia tawadlu' untuk tinggi dan tidak sombong agar ia tidak rendah. ${ }^{60}$ Rasulullah saw bersabda:

"Harta itu tidak berkurang karena sedekah, Allah tidak

menambahkan pada hamba yang memaafkan melainkan kemuliaan, dan tidaklah seseorang tawadlu' karena Allah melainkan Allah mengangkatnya." (Hadits Riwayat Muslim)

Sikap sombong muncul dari kesalahan menilai diri sebagai yang lebih baik, lebih mampu, lebih kaya atau rasa lebih lainnya. Orang yang sombong merasa bahwa kelebihan yang ada padanya semata merupakan hasil kerja yang ia lakukan. la tidak melihat kehadiran Allah swt dalam kehidupannya. Dengan pandangan seperti itu, wajar jika orang sombong senang membandingkan dirinya dengan orang lain.

Saat ia melihat orang lain lebih dari dirinya, ia merasa iri dan berbuat dengki. Sebaliknya, ia menemukan orang yang ia rasa lebih rendah darinya, dia merasa tinggi hati dan merendahkan orang lain. Sebagaimana Firman Allah swt dalam Qs. Al-Furqan ayat 63:

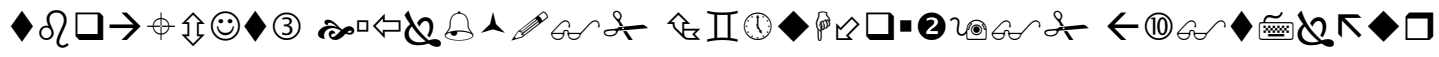
К:

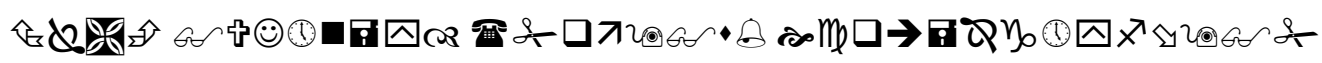
Artinya:

Dan hamba-hamba Tuhan yang Maha Penyayang itu (ialah) orang-orang yang berjalan di atas bumi dengan rendah hati dan apabila orang-orang jahil menyapa mereka, mereka mengucapkan kata-kata (yang mengandung) keselamatan.

Rasulullah saw bersabda:

Sesungguhnya Allah swt telah mewahyukan kepadaku agar kalian merendahkan diri sehingga seseorang tidak menyombongkan diri atas yang lain dan tidak berbuat zalim atas yang lain. (H.R Muslim no. 2588)

Bentuk-bentuk Tawadlu.

Diantara bentuk-bentuk tawadlu' orang muslim adalah sebagai berikut;

${ }^{60}$ Abu Bakar Jabir Al-Jazairi, Ensiklopedi Muslim”Minhajul Muslim”, terjemah, Jakarta: Darul Falah, 2004. HIm.252 
1. Jika seseorang seperti dirinya menonjolkan diri dipertemuan, maka ia sombong. Jika orang tersebut agak mundur ia tawadlu'

2. la berdiri dari kursinya untuk orang 'alim atau orang mulia dan mempersilahkannya duduk dikursinya. Jika orang 'alim atau orang mulia itu berdiri ia siapkan sandalnya/sepatunya, dan mengantarnya ke pintu rumahnya dengan berjalan dibelakangnya.

3. la berdiri untuk orang biasa, menghadapinya dengan wajah yang berseri-seri, lemah lembut ketika bertanya kepadanya, menjawab panggilannya, memenuhi kebutuhannya, dan tidak melihat dirinya lebih baik daripadanya.

4. la mau duduk bersama orang-orang miskin, orang-orang sakit, makan bersama-sama mereka, dan berjalan bersama mereka.

5. la mengunjungi orang-orang yang statusnya dibawahnya, atau orang yang selevel dengannya, membawa oleh-oleh untuknya, dan berjalan bersamanya untuk memenuhi kebutuhannya

6. Ia makan dan minum tanpa berlebihan, dan berpakaian dengan tidak sombong. ${ }^{61}$

\section{b. Contoh Tawadhu'}

1. Senantiasa bersikap sabar didalam pergaulan

2. Tidak suka menonjolkan diri (sombong)

3. Senantiasa menghargai dan menghormati orang lain. ${ }^{62}$

2. Taat

\section{a. Pengertian Taat}

Kata taat berasal dari bahasa arab $T a^{\prime} a t$ yang berarti mengikuti atau menuruti. Secara istilah taat berarti mengikuti dan menuruti keinginan atau perintah dari luar diri kita. Dengan kata lain, taat berarti tunduk dan patuh saat kita mendapat perintah atau larangan untuk dihindari.

Selain kepada Allah swt, manusia juga harus taat kepada Rasul dan Ulil Amri (Para pemimpin). Sebagaimana Firman Allah swt dalam surat Al-Nisa' ayat 59:

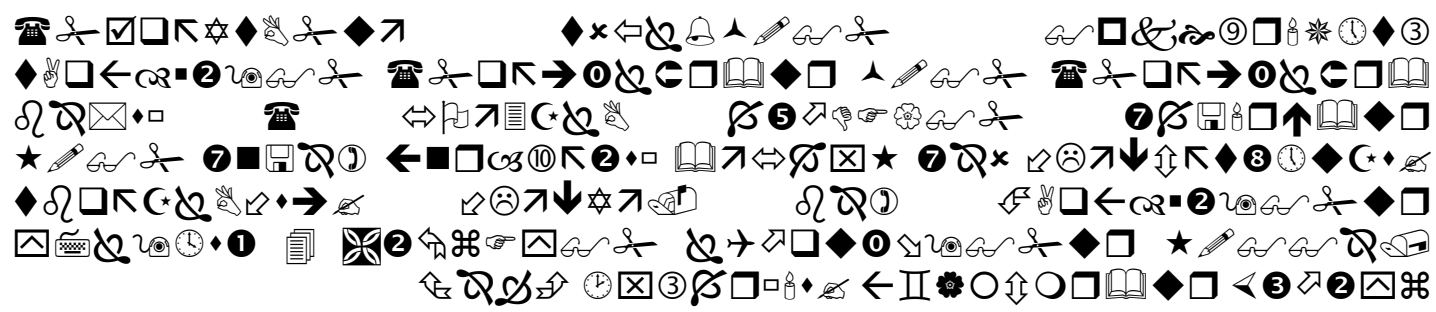

${ }^{61} \mathrm{Ibid}, \mathrm{h} / \mathrm{m} .255$

${ }^{62} \mathrm{https} / / /$ rohissmpsn14depok.wordpress.com 


\section{Artinya:}

Hai orang-orang beriman, taatilah Allah dan taatilah Rasul-Nya, dan ulil amri di antara kamu. Kemudian jika kamu berlainan pendapat tentang sesuatu, maka kembalikanlah ia kepada Allah (Al-Qur'an) dan Rasul (sunnahnya). Jika kamu benarbenar beriman kepada Allah dan hari kemudian itu lebih utama (bagimu) dan lebih baik akibatnya.

Allah swt adalah Khalik "pencipta" alam semesta beserta isinya. Rasulullah saw adalah utusan-Nya untuk seluruh manusia bahkan dengan kelahiran beliau alam semesta ini mendapat rahmat yang tidak ternilai harganya. Oleh karena itu, siapapun yang telah berikrar (syahadat) maka dengan sendirinya lahirlah suatu kewajiban dalam bentuk ketaatan kepada situasi dan kondisi apapun.

\section{b. Contoh Taat}

1. Senantiasa menjalankan perintah dan menjauhi larangan Allah swt

2. Senantiasa bersikap dan berbuat kebaikan kepada sesama

3. Senantiasa ikhlas dan sabar dalam beribadah kepada-Nya

4. Senantiasa berperilaku taat dalam kehidupan sehari-hari ${ }^{63}$

\section{Qana'ah}

\section{a. Pengertian Qana'ah}

Qana'ah merupakan sikap rela menerima atau merasa cukup dengan apa yang didapat serta menjauhkan diri dari sifat tidak puas dan merasa kekurangan yang berlebihlebihan. ${ }^{64}$ Orang yang memiliki sikap qana'ah sadar bahwa untuk mencapai suatu keinginan, harus dilakukan dengan usaha. Usaha yang dilakukkan pun bukan sekedar berusaha tanpa perencanaan dan kesungguhan. Ketika hasil dari usaha tersebut belum sesuai dengan keinginannya, maka ia menerimanya dengan ikhlas dan lapang dada.

Qana'ah bukan berarti hidup bermalas-malasan, tidak mau berusaha sebaik-baiknya untuk meningkatkan kesejahteraan hidup. Justru orang yang qana'ah itu selalu giat bekerja dan berusaha, namun apabila hasilnya tidak sesuai dengan yang diharapkan, ia akan tetap rela hati menerima hasil tersebut dengan rasa syukur kepada Allah swt. Sikap demikian itu akan mendatangkan rasa tentram dalam hidup dan menjauhkan diri dari sifat serakah atau tamak. Rasulullah bersabda :

\footnotetext{
${ }^{63} \mathrm{https}: / /$ rohissmpsn14depok.wordpress.com

${ }^{64}$ Husni Thoyar, Pendidikan Agama Islam (Jakarta: Pusat Kurikulum dan Pembukuan, 2011),hlm. 39.
} 
"Abdullah bin Amru r.a. berkata: Rasulullah saw bersabda, sesungguhnya beruntung orang yang masuk Islam dan rizkinya cukup dan merasa cukup dengan apa yang telah Allah swt berikan kepadanya. (H.R Muslim)

Orang yang memiliki sikap qana'ah, memiliki keyakinan bahwa apa saja yang diperoleh atau yang ada pada dirinya adalah ketentuan Allah swt. Sebagaimana Firman Allah swt dalam al-Qur'an surat Hud ayat 6:

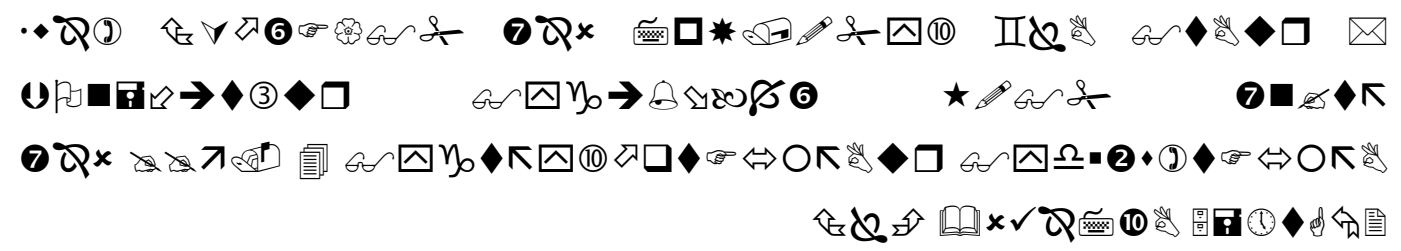

Artinya:

Dan tidak ada suatu binatang melata-pun di bumi melainkan Allah-lah yang memberi rizkinya, dan dia mengetahui tempat berdiam binatang itu dan tempat penyimpanannya. Semuanya tertulis dalam kitab yang nyata (Lauhul Mahfudz)

\section{b. Contoh Qana'ah}

1. Senantiasa bersyukur kepada Allah SWT

2. Hidup sederhana dan mau berinfak dijalan Allah

3. Tidak putus asa/cemas dala menghadapi masalah.

4. Menerima ketentuan Allah dengan ikhlas setelah usaha yang maksimal

5. Mengingat dan memikirkan nikmat Allah yang tiada duanya. ${ }^{65}$

\section{Iffah}

\section{a. Pengetian iffah}

Secara bahasa Iffah dalah menahan. Adapun secara istilah menahan diri sepenuhnya dari perkara-perkara yang Allah haramkan. Iffah adalah usaha memelihara dan menjauhkan diri dari hal-hal yang tidak halal, makruh, dan tercela.

Iffah merupakan akhlak paling tinggi dan dicintai Allah swt. Oleh karena itu, sifat ini perlu dilatih sejak usia anak-anak sehingga memiliki kemampuan dan daya tahan terhadap keinginan-keinginan yang tidak semua harus dituruti karena akan membahayakan saat telah dewasa.

\footnotetext{
${ }^{65}$ Husni Thoyar, Pendidikan Agama Islam (Jakarta: Pusat Kurikulum dan Pembukuan, 2011),hlm. 41.
} 
Dengan demikian, orang yang afif adalah orang yang bersabar dari perkara-perkara yang diharamkan walaupun jiwanya cenderung kepada perkara tersebut dan menginginkannya. ${ }^{66}$ Dari sifat Iffah inilah akan lahir sifat-sifat mulia seperti: sabar, qana'ah, jujur, santun, dan akhlak terpuji lainnya.

Allah swt berfirman dalam al-Qur'an surat Nur ayat 33

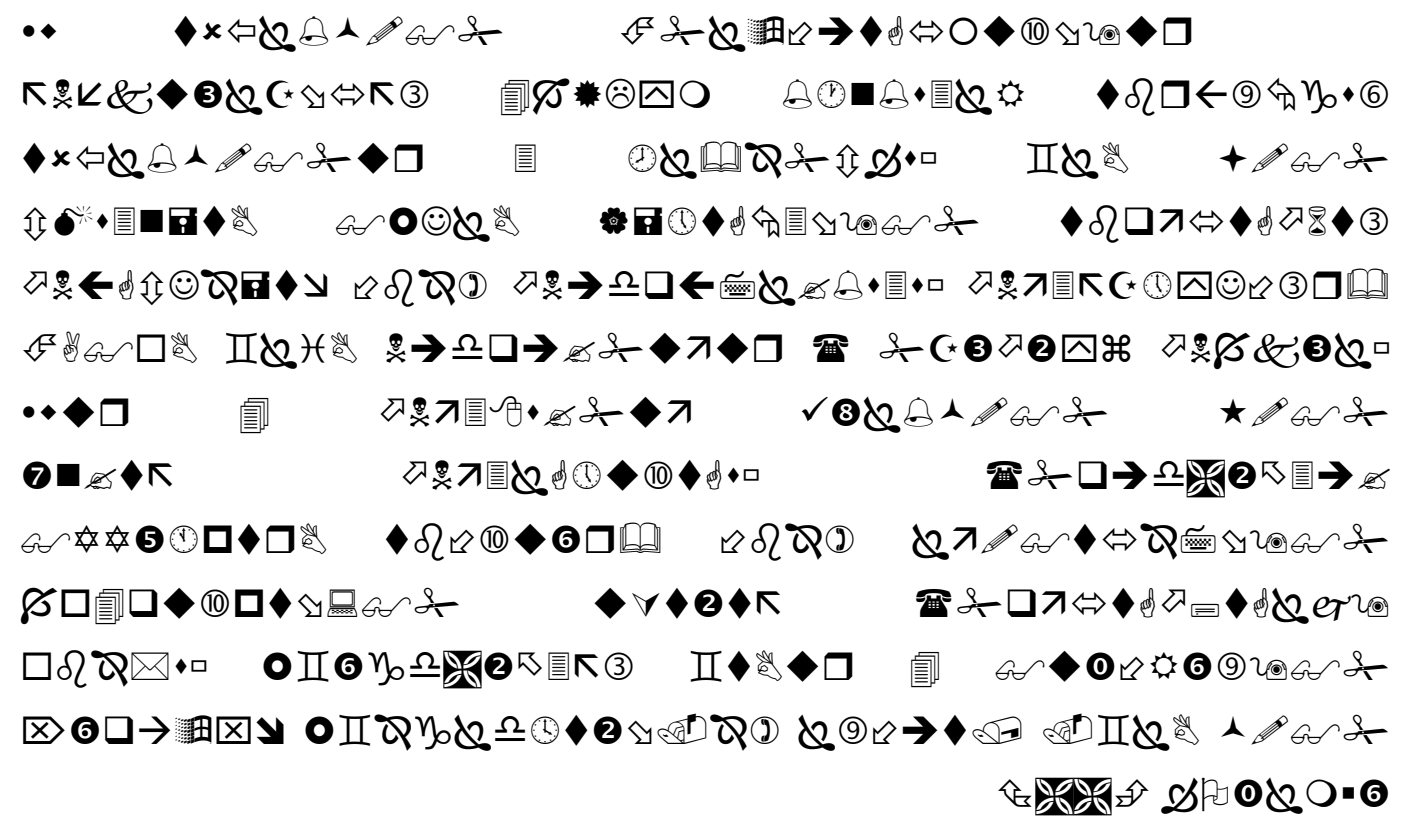

Artinya : dan orang-orang yang tidak mampu kawin hendaklah menjaga kesucian (diri)nya, sehingga Allah memampukan mereka dengan karunia-Nya. dan budak-budak yang kamu miliki yang memginginkan perjanjian, hendaklah kamu buat Perjanjian dengan mereka, jika kamu mengetahui ada kebaikan pada mereka, dan berikanlah kepada mereka sebahagian dari harta Allah yang dikaruniakan-Nya kepadamu. dan janganlah kamu paksa budak-budak wanitamu untuk melakukan pelacuran, sedang mereka sendiri mengingini kesucian, karena kamu hendak mencari Keuntungan duniawi. dan Barangsiapa yang memaksa mereka, Maka Sesungguhnya Allah adalah Maha Pengampun lagi Maha Penyayang (kepada mereka) sesudah mereka dipaksa itu.

Allah SWT berfirman dalam al-Qur'an surat al- Baqarah ayat 273.

(6) Qर

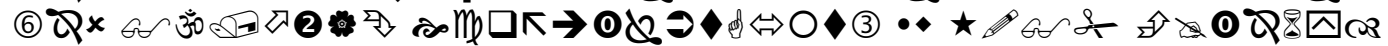

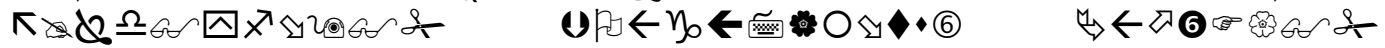

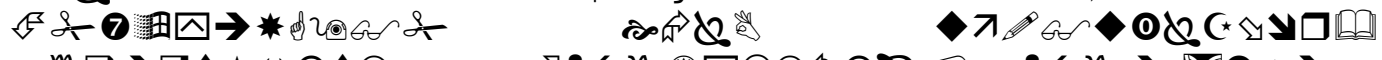

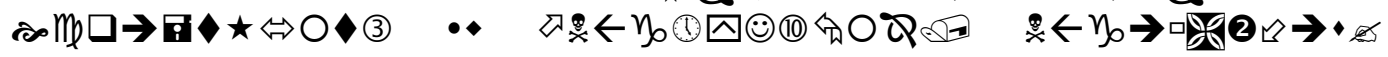

${ }^{66}$ Muhammad Ali Somali, Etika Modern (Jakarta: Nur Al-Huda, 2014), hlm. 143. 


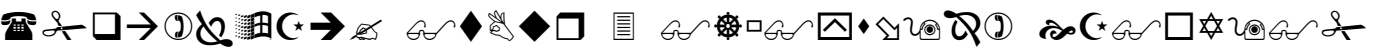

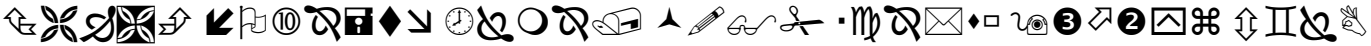

Artinya:

(Berinfaqlah) kepada orang-orang fakir yang terikat (oleh jihad) di jalan Allah; mereka tidak dapat (berusaha) di bumi; orang yang tidak tahu menyangka mereka orang Kaya karena memelihara diri dari minta-minta. kamu kenal mereka dengan melihat sifatsifatnya, mereka tidak meminta kepada orang secara mendesak. dan apa saja harta yang baik yang kamu nafkahkan (di jalan Allah), Maka Sesungguhnya Allah Maha Mengetahui.

b. Contoh Iffah

1. Kesucian panca indra

2. Kesucian dari memakan harta orang lain

3. Kesucian jasad

4. Kesucian lisan ${ }^{67}$

${ }^{67}$ http://asysyariah.com/keutamaan-iffah-dan-bersabar.html 


\section{BAB IV}

IMAN, IKHLAS, DAN IBADAH

\section{Capaian Perkuliahan}

1. Mampu memahami dengan benar makna iman, ikhlas, dan ibadah

2. Mampu mendeskripsikan urgensi dan unsur-unsur Iman, Ikhlas serta ibadah

3. Mampu meneladankan sikap dan perilaku ikhlas dalam kehidupan sehari-hari

4. Mampu menguasai konsep Ibadah dan mempraktekkan ibadah sesuai perintah Allah swt dan tuntunan Rasuluullah saw

A. Iman

\section{Pengertian Iman}

Secara bahasa "iman" berarti pembenaran hati, kemantapan hati atau percaya. Sedangkan secara syari'at "iman" berarti mengetahui Allah swt dan sifat-sifatnya disertai dengan menjalankan semua perintah-Nya dan menjauhi semua yang dilarang-Nya. Didalam al-Qur'an, Allah swt telah menjelaskan pengertian orang yang beriman seperti Firman Allah swt dalam alQur'an surat. al-Baqarah ayat 3:

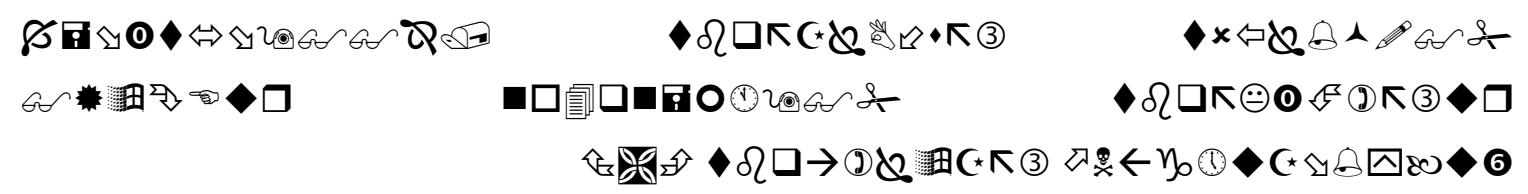

Artinya: orang yang beriman adalah mereka yang beriman kepada yang ghaib, yang mendirikan shalat, dan menafkahkan sebagian rezki yang Kami anugerahkan kepada mereka. ${ }^{68}$

Isi kandungan ayat di atas adalah sebagai berikut:

1. Iman ialah kepercayaan yang teguh yang disertai dengan ketundukan dan penyerahan jiwa. tanda-tanda adanya iman ialah mengerjakan apa yang dikehendaki oleh iman itu.

\footnotetext{
${ }^{68}$ Depag RI, al-Qur'an dan Terjamah, .
} 
2. Yang ghaib ialah yang tak dapat ditangkap oleh panca indera. percaya kepada yang ghaib yaitu, mengi'tikadkan adanya sesuatu yang maujud yang tidak dapat ditangkap oleh panca indera, karena ada dalil yang menunjukkan kepada adanya, seperti: adanya Allah, malaikatmalaikat, hari akhirat dan sebagainya. ${ }^{69}$

3. Shalat menurut bahasa 'Arab artinya: doa. menurut istilah Shalat ialah ibadah yang dimulai dengan takbir dan disudahi dengan salam, yang dikerjakan untuk membuktikan pengabdian dan kerendahan diri kepada Allah swt. mendirikan shalat ialah menunaikannya dengan teratur, dengan melangkapi syarat-syarat, rukun-rukun dan adab-adabnya, baik yang lahir ataupun yang batin, seperti khusu', memperhatikan apa yang dibaca dan sebagainya.

4. Rezki: segala yang dapat diambil manfaatnya. menafkahkan sebagian rezki, ialah memberikan sebagian dari harta yang telah direzkikan oleh Tuhan kepada orang-orang yang disyari'atkan oleh agama memberinya, seperti orang-orang fakir, orang-orang miskin, kaum kerabat, anak-anak yatim dan lain-lain. ${ }^{70}$

\section{Sebab-Sebab Turunnya Iman}

\section{Sebab dari dalam :}

1. Kebodohan

Ini adalah salah satu penyebab yang terbesar bagi turunnya iman, sebagaimana ilmu adalah salah satu penyebab terbesar bagi naiknya iman. Seorang muslim yang berilmu tidak mengutamakan cinta dan perbuatan hal-hal yang merugikan dan menyebabkan sakit dirinya daripada perbuatan yang membawa keuntungannya, keberhasilan dan kebersihan lahir batinya.

Orang yang bodoh bahkan sebaliknya, karena perbuatan kebodohan yang melampaui batas yang ia kerjakan dan karena kurangnya ilmu, dia mungkin lebih mengutamakan pada hal-hal yang membawa kepada kerugiannya. ${ }^{71} \mathrm{Hal}$ ini karena ukuran dalam dirinya telah

\footnotetext{
${ }^{69}$ Al-Khaubawi, Usman bin Hasan bin Ahmad Syakir, Durratun Nashihiin, Beirut. judul. (tempat Penerbit: Darul Kitab Al-Islamiy, 1949).

${ }^{70}$ Al-Khaubawi, Usman bin Hasan bin Ahmad Syakir, Durratun Nashihiin. (Beirut: Darul Kitab Al-Islamiy, 1949).

${ }^{71}$ Syaikh Abdur Razzaaq al-Abbaad. Sebab-Sebab Naik Turunya Iman. (Jakarta: Cakrawala Publishing, 2004). 122.
} 
berubah dari atas ke bawah dan juga karena sudut pandangnya yang lemah. IImu terletak pada akar semua kebaikan dan kebodohan terletak pada akar semua kejahatan. ${ }^{72}$

2. Ketidak pedulian, keengganan, dan melupakan

Ketiga hal ini merupakan penyebab yang luar biasa bagi menurunya iman. Seorang yang terpukaul dengan ketidak pedulian, disukarkan dengan melupakan dan berpaling, maka imannya akan menurun sesuai dengan kehadiran daripada ketiga penyebab ini. Itu akan menimbulkan penyakit hati atau kematian karena pengaruhnya oleh kesalahan pandangan dan Hawa nafsu.

Mengenai ketidakpedulian, Allah swt telah menghukum itu dalam kitab-nya dan Allah menyebutkan bahwa itu adalah prilaku tercela, dan merupakan ciri perbuatan orang yang tidak beriaman dan orang munafik. ${ }^{73}$ Allah swt mengingatkan tentang hal ini dengan sangat kerasnya. Sebagaimana dal al-Qur'an surat al-A'raaf ayat 179

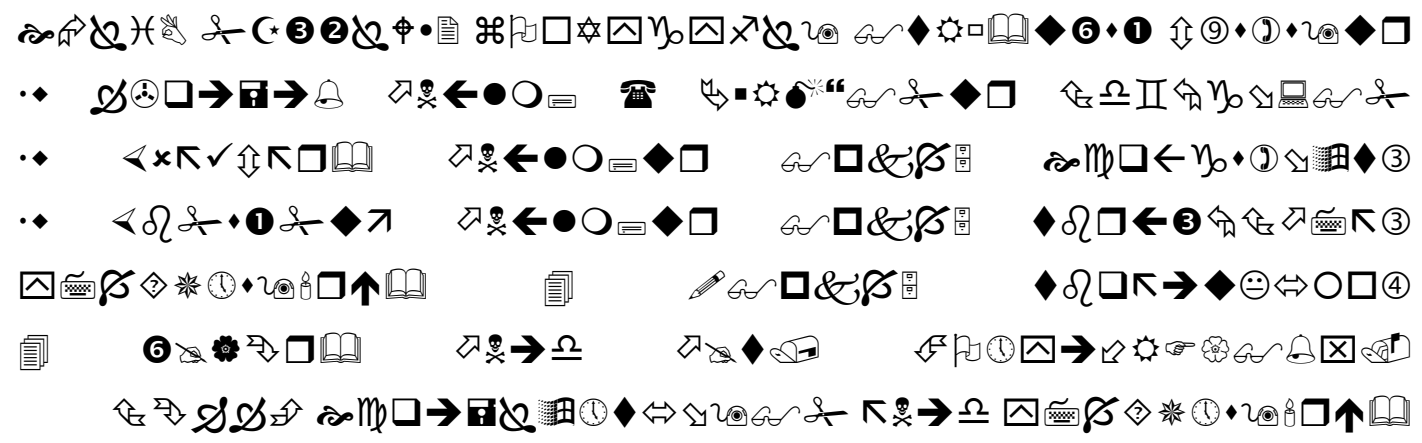

Dan Sesungguhnya kami jadikan untuk (isi neraka Jahannam) kebanyakan dari jin dan manusia, mereka mempunyai hati, tetapi tidak dipergunakannya untuk memahami (ayatayat Allah) dan mereka mempunyai mata (tetapi) tidak dipergunakannya untuk melihat (tanda-tanda kekuasaan Allah), dan mereka mempunyai telinga (tetapi) tidak dipergunakannya untuk mendengar (ayat-ayat Allah). mereka itu sebagai binatang ternak, bahkan mereka lebih sesat lagi. mereka Itulah orang-orang yang lalai." ${ }^{74}$

3. Perbuatan tidak patuh dan melakukan perbuatan berdosa

Kerugian dan dampak yang jelek dari faktor ini terhadap kondisi iman sangatlah jelas. Iman akan bertambah dengan kepatuhan dan menurun dengan ketidakpatuhan. Hanya dengan melakukan amal wajib dan amal sunnah yang Allah swt telah tetapkan akan

\footnotetext{
${ }^{72}$ Syaikh Abdur Razzaaq al-Abbaad. Sebab-Sebab Naik Turunya Iman. (Jakarta: Cakrawala Publishing, 2004). 123.

${ }^{73}$ Ibid. 129.

${ }^{74}$ Syaikh Abdur Razzaaq al-Abbaad. Sebab-Sebab Naik Turunya Iman. (Jakarta: Cakrawala Publishing, 2004). 129.
} 
menambah iman, sedangkan perbuatan terlarang dan tidak di sukai Allah swt bisa menurunkan iman.

Bagaimanapun juga, derajat dosa berbeda tingkatannya, sesuai dengan kejahatan yang mereka datangkan dan kehebatan kerugian yang ditimbulkannya.

Ini seperti yang dikatakan Ibnu Qayyim al-Jauziyyah:

tanpa ragu lagi kufur, fasiq, dan ketidakpatuhan adalah bertingkat-tingkat seperti juga iman dan amal shaleh juga bertingkat-tingkat.

Allah berfirman dalam al-Qur'an surat Ali- Imran : 163

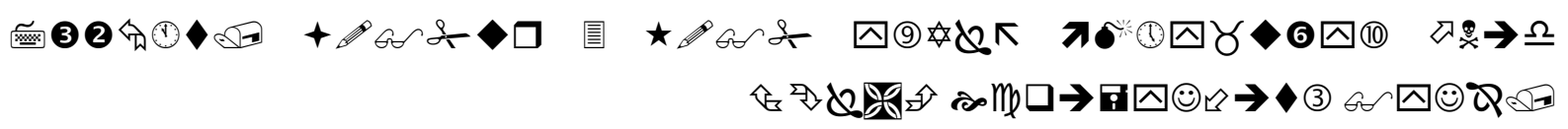

Artinya: Kedudukan mereka itu bertingkat-tingkat di sisi Allah, dan Allah Maha melihat apa yang mereka kerjakan. ${ }^{75}$

4. Jiwa yang selalu memerintahkan berbuat jahat

Ini adalah jiwa yang terhukum, yang mana Allah swt meletakkan kejahatan di dalamnya kepada seseorang. Jiwa itu memerintahkan dia kepada setiap kejahatan, mengundangnya kepada semua resiko dan membimbingnya kepada setiap kekerasan.

Ini adalah tabiat dan perangainya, kecuali kepada jiwa yang Allah swt berikan Tauhid dan menguatkan serta membantunya. Tidak ada yang terselamatkan dari kejahatan jiwanya kecuali dengan tauhid dari Allah swt, sebagaimana firman Allah dalam al-Qur'an surat Yusuf : 53

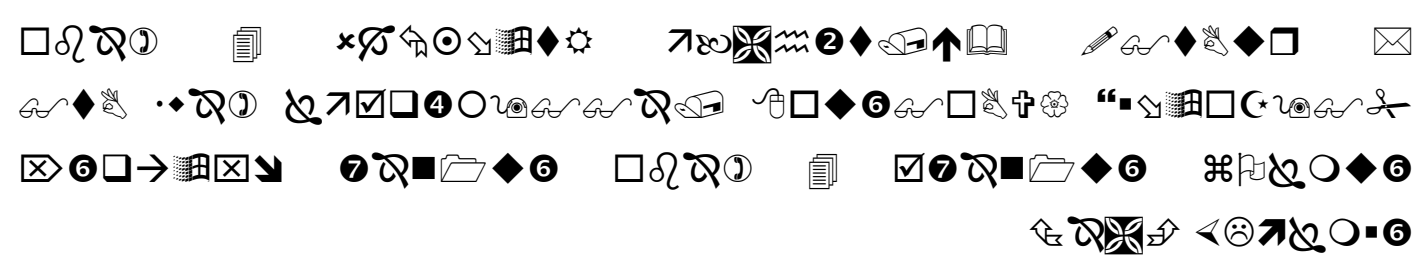

Artinya: Dan Aku tidak membebaskan diriku (dari kesalahan), Karena Sesungguhnya nafsu itu selalu menyuruh kepada kejahatan, kecuali nafsu yang diberi rahmat oleh Tuhanku. Sesungguhnya Tuhanku Maha Pengampun lagi Maha penyanyang. ${ }^{76}$

\section{Sebab-sebab dari luar}

1. Syaitan

\footnotetext{
${ }^{75}$ Ibid. 135.

${ }^{76}$ Syaikh Abdur Razzaaq al-Abbaad. Sebab-Sebab Naik Turunya Iman. (Jakarta: Cakrawala Publishing, 2004). 145.
} 
Syaitan memegang peran untuk menjadi alasan dari lluar yang kuat, yang menyebabkan iman turun. Syaitan adalah musuh yang hebat bagi orang yang beriman. Dia menimbulkan bencana untuk menyusahkan kaum beriman. Segala sikap dan perilaku setan ditujukan untuk merusak pribadi orang-orang yang selalu tunduk kepada Allah dan rasulNya. la tidak rela membiarkan kebajikan dan kebenaran tegak di muka bumi ini, selalu saja setan ingin mencari teman sebanyak-banyaknya hingga hari akhir tiba.

Gambar 1.10
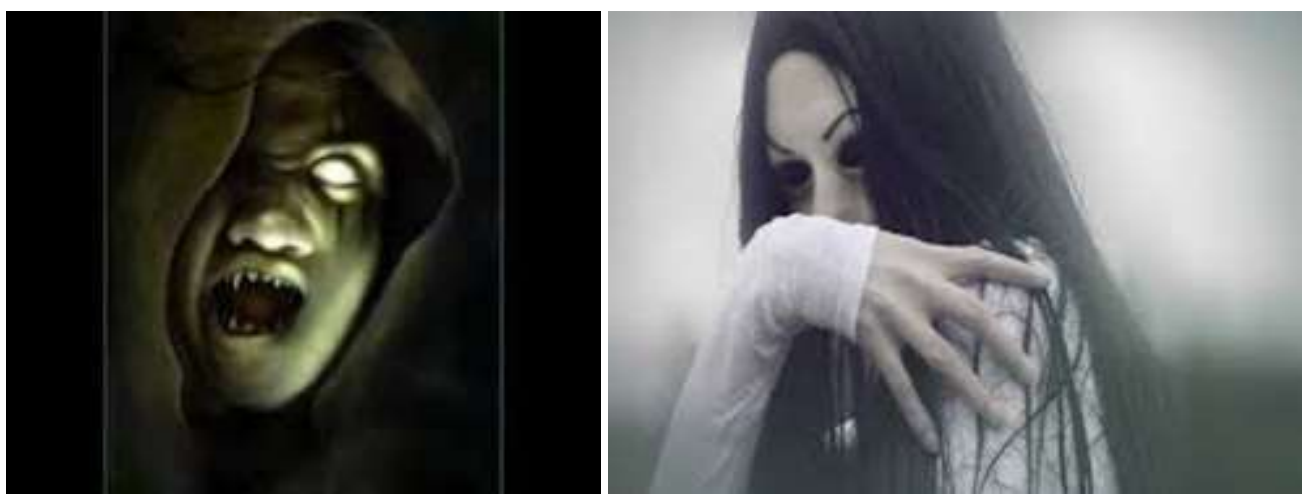

Dia (Syaitan) tidak mempunyai keinginan atau tujuan selain memukul iman atau menjatuhkan Iman seseorang sehingga menjadi kufur, murtad, dan syirik. Upaya apa saja yang dilakukakan setan untuk melemahkan dan merusaknya. ${ }^{77}$ Siapa saja yang megikuti bisikannya, menyetujui pemikirannya dan tidak kembali kepada Allah swt untuk berlindung dari syaitan tersebut, imannya akan melemah dan menurun. Sesungguhnya iman bisa menghilang secara keseluruhan tergantung tindakan seorang muslim atas bisikan dan pendapat syaitan itu.

Allah swt telah menjelaskan bahwa bahayanya telah mengikuti syaitan sebagaimana fakta, dia adalah musuh orang-orang yang beriman. Allah swt memerintahkan oran-orang yang beriman untuk memosisikan syaitan sebagai musuh mereka dan oleh sebab itu manusia harus membebaskan diri mereka sendiri dari bisikan syaitan.

Allah berfirman dalam al-Qur'an surat al-Nuur :21

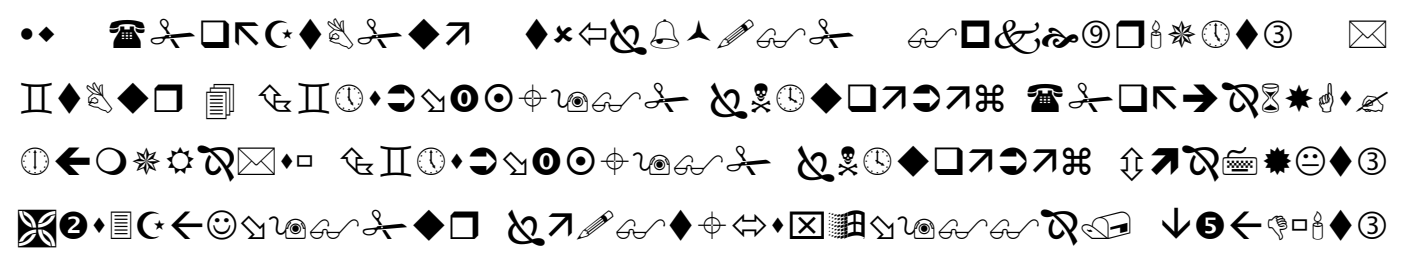

${ }^{77}$ Ibid. 152. 


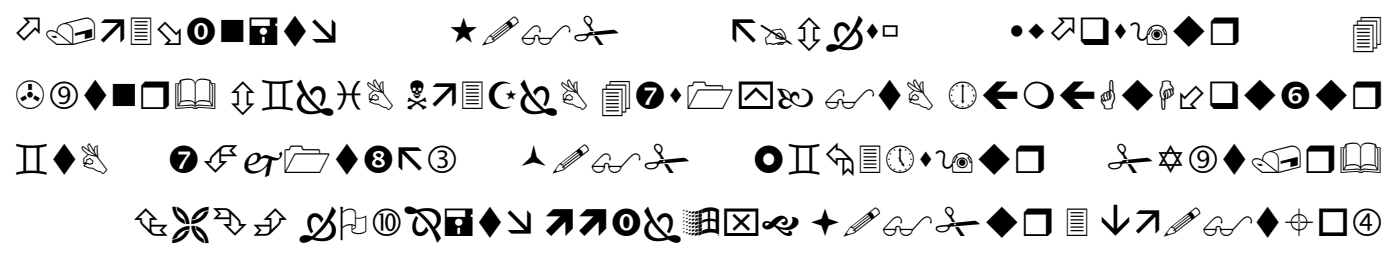

Artinya: Hai orang-orang yang beriman, janganlah kamu mengikuti langkah- langkah syaitan. barangsiapa yang mengikuti langkah-langkah syaitan, Maka Sesungguhnya syaitan itu menyuruh mengerjakan perbuatan yang keji dan yang mungkar. sekiranya tidaklah Karena kurnia Allah dan rahmat-Nya kepada kamu sekalian, niscaya tidak seorangpun dari kamu bersih (dari perbuatan-perbuatan keji dan mungkar itu) selama-lamanya, tetapi Allah membersihkan siapa yang dikehendaki-Nya. dan Allah Maha mendengar lagi Maha Mengetahui. ${ }^{78}$

Allah swt berfirman dalam al-Qur'an surat Faathir :6

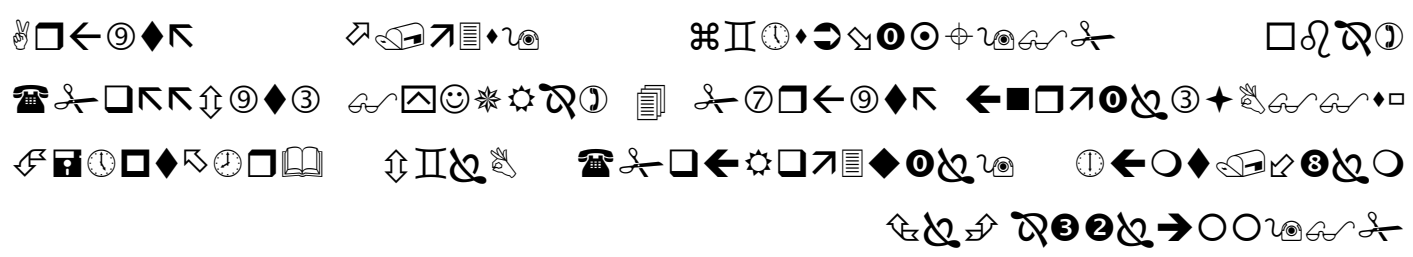

Artinya: Sesungguhnya syaitan itu adalah musuh bagimu, Maka anggaplah ia musuh(mu), Karena Sesungguhnya syaitan-syaitan itu Hanya mengajak golongannya supaya mereka menjadi penghuni neraka yang menyala-nyala. ${ }^{79}$

2. Bujukan dan Rayuan Dunia

Ini adalah faktor luar ke-2, yang menimbulkan dampak pada penurunan iman seseorang. Dari sini salah satu penyebab turunya iman seseorang adalah untuk di sita dalam hal-hal yang fana dari dunia yang sementara ini, untuk memenuhi waktu seseorang denganya, dipersembahkan untuk mencarinya dan untuk berlomba dengan kesenanganya, godaan dan bujukannya.

Kapan saja orang rindu dengan kehebatan dunia ini dan hatinya menjadi tertarik kepadanya, maka ketaatannya akan melemah dan imanya akan berkurang sesuai ketertarikannya kepada dunia itu.

\footnotetext{
${ }^{78}$ Syaikh Abdur Razzaaq al-Abbaad. Sebab-Sebab Naik Turunya Iman. (Jakarta: Cakrawala Publishing, 2004). 153.

${ }^{79}$ Syaikh Abdur Razzaaq al-Abbaad. Sebab-Sebab Naik Turunya Iman. (Jakarta: Cakrawala Publishing, 2004). 153.
} 
Allah swt maha bijaksana, yng mencelah dunia ini dalam kitabnya dan menjelaskan tentang kemelaratan dan keburukan dunia dalam ayat Al-Quran. ${ }^{80}$

Allah berfirman dalam al-Qur'an surat al-Hadid : 20

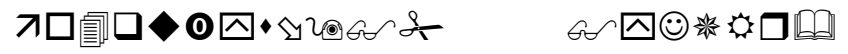

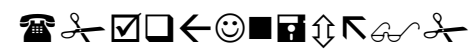

$\langle\square \wedge$ (3) (3)

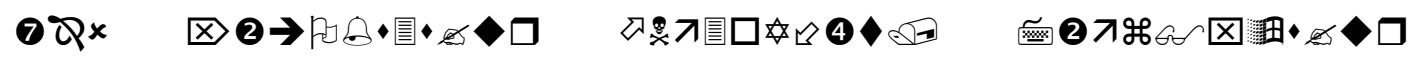

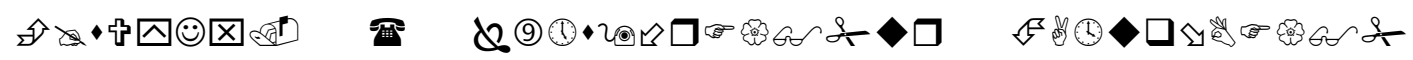
(1)

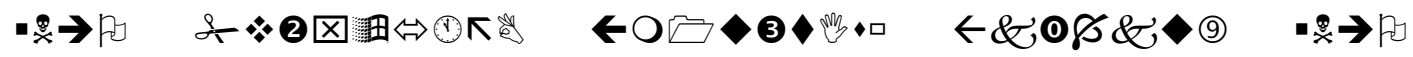

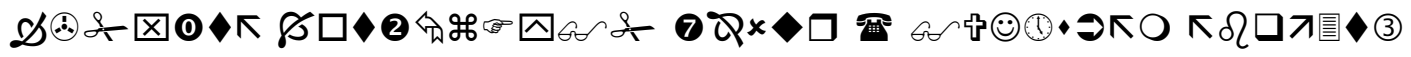

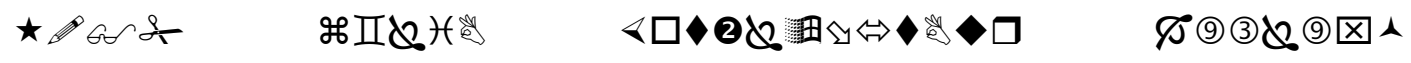

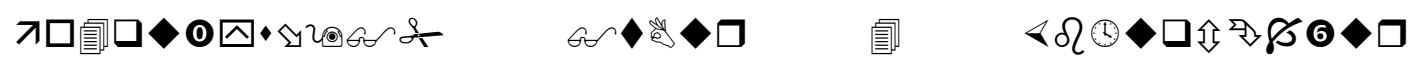

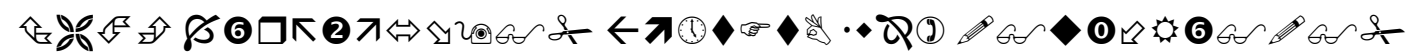
Artinya: Ketahuilah, bahwa Sesungguhnya kehidupan dunia Ini hanyalah permainan dan suatu yang melalaikan, perhiasan dan bermegah- megah antara kamu serta berbanggabanggaan tentang banyaknya harta dan anak, seperti hujan yang tanam-tanamannya mengagumkan para petani; Kemudian tanaman itu menjadi kering dan kamu lihat warnanya kuning Kemudian menjadi hancur. dan di akhirat (nanti) ada azab yang keras dan ampunan dari Allah serta keridhaan-Nya. dan kehidupan dunia Ini tidak lain hanyalah kesenangan yang menipu.

Allah swt berfirman dalam al-Qur'an surat al-Kahfi : 45-46

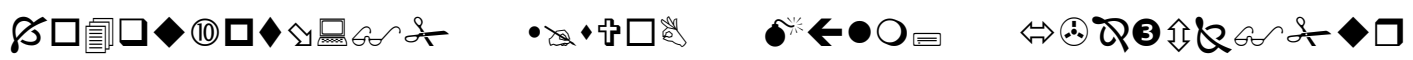

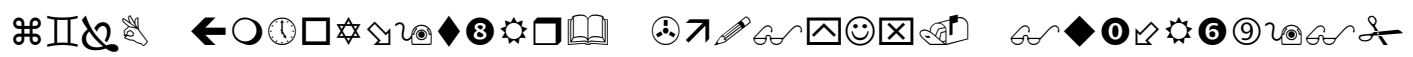

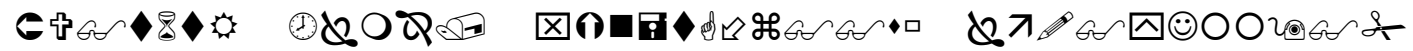

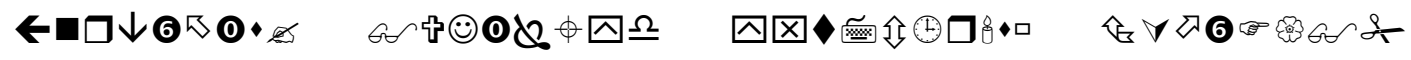

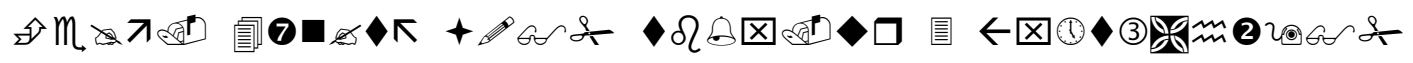

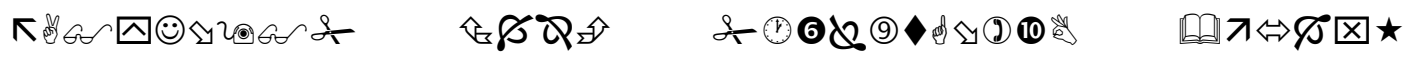

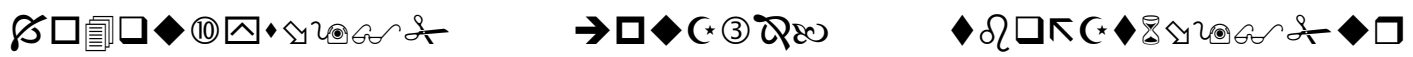

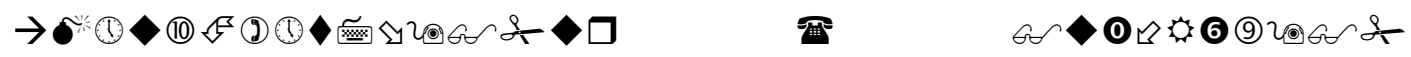

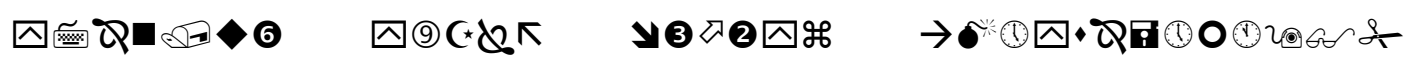

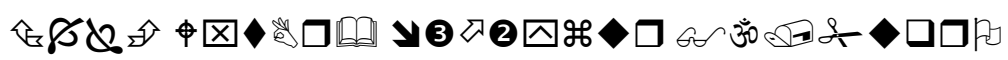

Artinya: Dan berilah perumpamaan kepada mereka (manusia), kehidupan dunia sebagai air hujan yang kami turunkan dari langit, Maka menjadi subur karenanya tumbuh-tumbuhan

${ }^{80}$ Ibid. 158. 
di muka bumi, Kemudian tumbuh-tumbuhan itu menjadi kering yang diterbangkan oleh angin. dan adalah Allah, Maha Kuasa atas segala sesuatu. ${ }^{81}$

3. Pergaulan yang buruk

Mereka adalah orang yang merugi bagi orang yang beriman, baik dalam sikap dan perilaku. ${ }^{82}$ Bercampur dengan mereka yang menemani mereka adalah penyebab terbesar yang bisa menurunkan dan memperlemah iman seseorang.

"seseorang itu terletak pada agama dan teman dekatnya, sehingga masing-masing kamu sebaiknya melihat kepada siapa dia mengambil teman dekatnya ".83

3. Rukun Iman

1. Beriman kepad Allah swt, Tuhan yang maha esa lagi maha penyanyang

2. Beriman kepada malaikat-malaikat Allah $s w t^{84}$

3. Beriman kepada Rasul (para utusan Allah swt)

4. Beriman kepada kitab-kitab Allah swt

5. Beriman kepada hari akhir

6. Beriman kepada takdir (ketentuan/ketetapan Allah swt). ${ }^{85}$

4. Ayat-ayat tentang iman:

1. Iman kepada Allah swt:

-al-Baqarah ayat $(62,255-285)$

- al-Nisaa' ayat (136)

-al-A'raaf ayat (158)

-al-Hasyar ayat (22-24)

-al-Taqhaabun ayat (8)

2. Iman kepada Malaikat:

-al-Baqarah ayat (285)

-al-Nisaa' ayat $(136)^{86}$

\footnotetext{
${ }^{81}$ Syaikh Abdur Razzaaq al-Abbaad. Sebab-Sebab Naik Turunya Iman. (Jakarta: Cakrawala Publishing, 2004). 159.

${ }^{82}$ Ibid. 164

${ }^{83}$ Syaikh Abdur Razzaaq al-Abbaad. Sebab-Sebab Naik Turunya Iman. (Jakarta: Cakrawala Publishing, 2004). 165.

${ }^{84}$ Muhammad BagirAl-Habsyi, Fiqih praktis menurut Al-Quran,As-sunnah,dan pendapat para ulama.

(Bandung: Mizan. 1999) .43.

${ }^{85}$ Ibid. 44.

${ }^{86}$ Barmawi Umary. Materi Akhlak. (Solo: CV. Ramadhani. 1967). 13.
} 
3. Iman kepada Kitab

-al-Baqarah ayat (1-5 \&176)

-al-Nisaa' ayat (136)

-Fushshilat ayat (3) ${ }^{87}$

-al-Taghabun ayat (8)

4. Iman kepada Rasul

-al-Nisaa' ayat (136)

-al-A'raaf ayat (158)

- al-Taghabun ayat (8)

5. Iman kepada Hari akhir

-al-Baqarah ayat (62)

- al-Nisaa' ayat (136)

6. Iman kepada Takdir

-al-Maryam ayat (19-20)

-al-Ahzaab ayat (38)

-al-Qamar ayat $(49)^{88}$

\section{B. Ikhlas}

1. Pengertian Ikhlas

Secara umum, ikhlas berarti hilangnya rasa pamrih atas segala sesuatu yang diperbuat. Menurut kaum sufi, seperti dikemukakan Abu Zakaria Al-Anshari, orang yang ikhlas adalah orang yang tidak mengharapkan apa-apa lagi. Karena itu, jika seseorang masih mengharapkan imbalan dari perbuatannya, maka ikhlasnya tidak sempurna, bahkan dapat disebut orang yang ria. jadi, ikhlas itu bersihnya motif dalam berbuat; semata-mata hanya menuntut rida Allah swt tanpa menghiraukan imbalan dari selain-Nya. ${ }^{89}$

Ikhlas adalah niat di dalam hati, hanya semata-mata karena Allah swt dan hanya untuk mengharapkan keridhaanNya belaka selama itu dikerjakan. Jadi seseorang yang melakukan amalan dengan ikhlas itu, sekalipun betapa besarnya nilai amalan tersebut, tetapi disimpannya sendiri dan tidak diperlihatkan, sebagaimana ia enggan memperlihatkan ketika ia melakukan kejahatan..$^{90}$

\footnotetext{
${ }^{87}$ Ibid. 14.

${ }^{88}$ Barmawi Umary. Materi Akhlak. (Solo: CV. Ramadhani. 1967). 14.

${ }^{89}$ Supiana, M.Karman. Materi Pendidikan Agama Islam. (Bandung: Remaja Rosdakarya. 2004). 233.

${ }^{90}$ Moh Abdai Rathomy. Sendi Agama Tauhid Fiqih Tasawuf. (Tiga Serangkai. 1983). 390.
} 
Juga andai kata sampai dimaklumi orang, maka orang beramal dengan ikhlas itu tadi akan merasa sama saja dalam hatinya, yakni diketahui atau tidak, perasaannya tidaklah berubahubah, hatinya tetap gembira dan tidak susah. Oleh sebab itu, amalan yang tercampur dengan maksud lain yang selain karena Allah swt, maka sudah tidak dapat dinamakan ikhlas lagi. ${ }^{91}$

Dzun Al-Nun Al-Misri mengatakan, ada tiga ciri orang yang ikhlas yaitu seimbang sikap dalam menerima pujian dan celaan orang, lupa melihat perbuatan dirinya, dan lupa menuntut balasan di akhirat kelak. Sejalan dengan pendapat Dzun al-Nun, Abu Abbas bin Atha mengatakan bahwa ikhlas adalah perbuatan-perbuatan yang bersih dari maksud-maksud tertentu yang diinginkan oleh pelaku dari perbuatan tersebut. ${ }^{92}$

2. Contoh Perilaku Ikhlas

Sebagai bukti penghayatan dan pengamalan, Allah swt menjelaskan dalam al-Qur'an surat al-Nisa ayat 164:

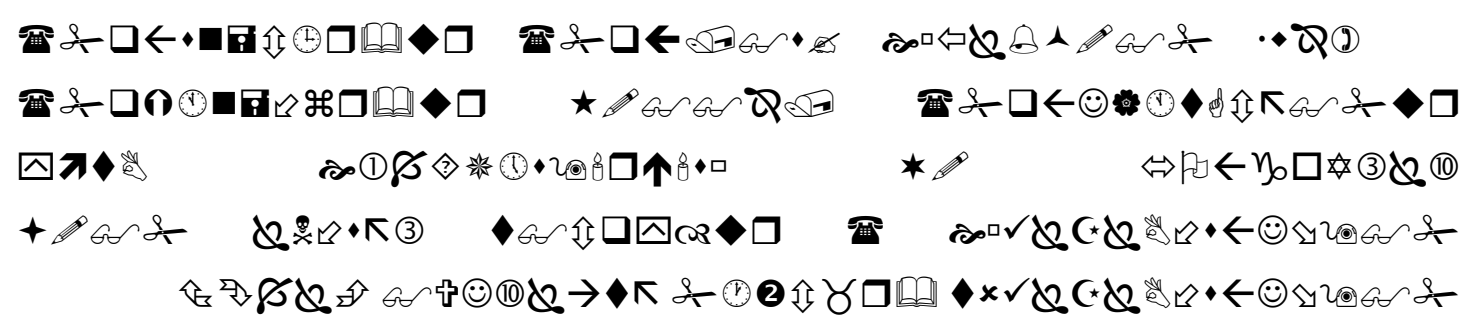

kecuali orang-orang yang taubat dan Mengadakan perbaikan dan berpegang teguh pada (agama) Allah dan tulus ikhlas (mengerjakan) agama mereka karena Allah. Maka mereka itu adalah bersama-sama orang yang beriman dan kelak Allah akan memberikan kepada orang-orang yang beriman pahala yang besar..$^{93}$

Dari ayat diatas dijelaskan bahwa orang-orang yang tulus ikhlas mengerjakan Agama karena Allah swt akan mendapatkan balasan berupa pahala yang besar. Adapun perilaku ikhlas dalam kehidupan sehari-hari dapat diwujudkan dengan cara:

a. Gemar melakukan perbuatan terpuji dan tidak dipamerkan kepada orang lain;

b. Ikhlas dalam beribadah, semata-mata karena Allah swt;

c. Tidak mengharapkan pujian atau sanjungan dari orang lain;

d. Selalu berhati-hati dalam bertindak atau berperilaku;

e. Tidak pernah membedakan antara amal besar dan amal kecil;

\footnotetext{
91 Ibid,. 390

${ }^{92}$ Supiana. M. Karman. Materi Pendidikan Agama Islam. 233

${ }^{93}$ Departemen Agama RI, al-Qur'an dan Terjemahnya.
} 
f. Tidak menghitung-hitung apalagi mengungkit-ungkit kebaikan yang pernah diberikan kepada orang lain. ${ }^{94}$

3. Ayat Tentang Ikhlas

Beberapa ayat al-Quran yang menjelaskan tentang ikhlas diantaranya:

Allah berfirman dalam Qs. al-Nisa; 58

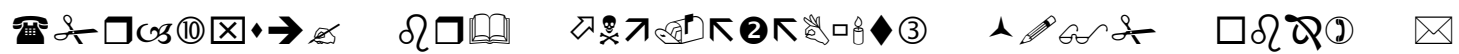

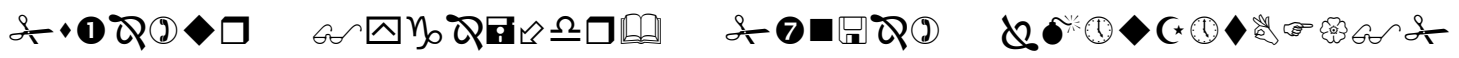

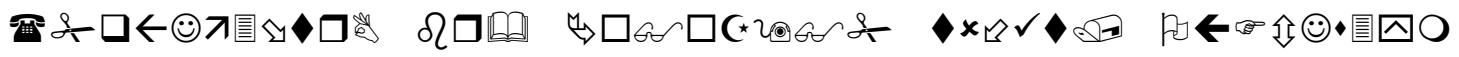

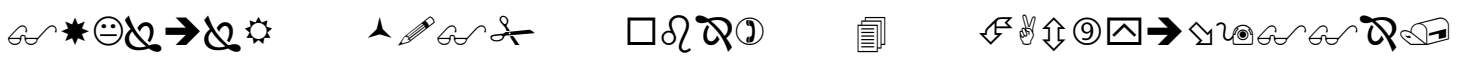

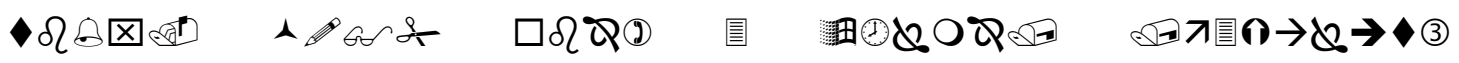

$$
\begin{aligned}
& \text { 合 QPQ }
\end{aligned}
$$

Sesungguhnya Allah menyuruh kamu menyampaikan amanat kepada yang berhak menerimanya, dan (menyuruh kamu) apabila menetapkan hukum di antara manusia supaya kamu menetapkan dengan adil. Sesungguhnya Allah memberi pengajaran yang sebaik-baiknya kepadamu. Sesungguhnya Allah adalah Maha mendengar lagi Maha melihat. ${ }^{95}$

Allah swt berfirman dalam al-Qur'an surat al-Baqarah ayat 139

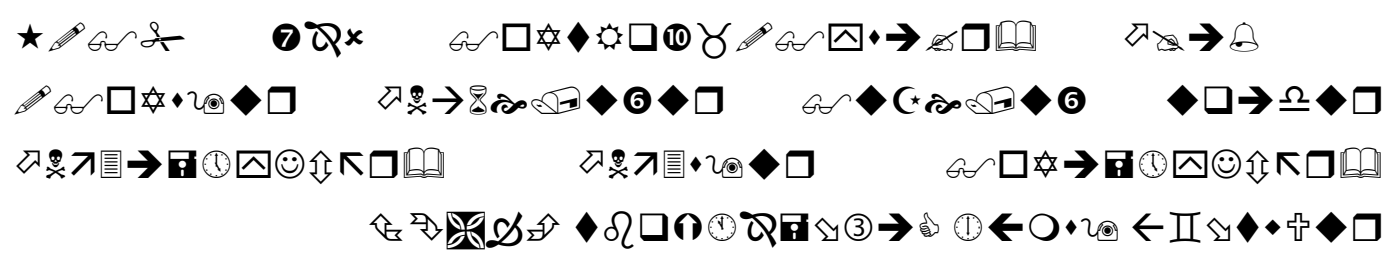

Katakanlah: "Apakah kamu memperdebatkan dengan Kami tentang Allah, Padahal Dia adalah Tuhan Kami dan Tuhan kamu; bagi Kami amalan Kami, dan bagi kamu amalan kamu dan hanya kepada-Nya Kami mengikhlaskan hati. ${ }^{96}$

\section{c. Ibadah}

1. Pengertian dan Ruang Lingkup Ibadah

Ibadah yaitu aturan agama yang mengatur hubungan manusia dengan Tuhan penciptanya yang dirumuskan dalam ajaran "Lima Rukun Islam", yakni:

a. Syahadat

\footnotetext{
${ }^{94}$ Kementerian Pendidikan dan Kebudayaan. Pendidikan Agama Islam dan Budi Pekerti. Edisi revisi. (Jakarta: Kementerian Pendidikan dan Kebudayaan. 2014). 195.

95 Departemen Agama RI, al-Qur'an dan Terjamah, QS. An-Nisa' (4): 58.

${ }^{96}$ Departemen Agama RI, al-Qur'an dan Terjemahnya.
} 

b. Shalat
c. Zakat
d. Puasa
e. Haji

Ibadah menurut Islam mempunyai dua pengertian yaitu: ${ }^{97}$

a. Ibadah dalam pengertian khusus, yaitu "Lima Rukun Islam" yang wajib dilakukan oleh setiap Muslim dengan catatan: zakat hanya diwajibkan bagi orang Islam yang telah memiliki kekayaan (harta benda) dalam jumlah tertentu (nisab) dan telah jatuh temponya (haul), dan haji hanya wajib bagi orang Islam yang telah mampu, baik dalam segi materialnya (keuangannya), maupun dalam segi jasmani dan rohaninya (sehat), dan aman perjalanannya. Haji wajib dilakukan sekali untuk seumur hidup. ${ }^{98}$

b. Ibadah dalam arti yang luas atau umum, yaitu segala perbuatan yang dilakukan seseorang dengan niat mencari keridlaan Allah swt, seperti seorang suami pergi ke tempat pekerjaan untuk menyukupi kebutuhan keluarganya - material dan spiritual - adalah ibadah, apabila disertai niat untuk mencari keridlaan Allah swt dengan jalan melaksanakan perintah agamanya, yakni suami wajib mencari nafkah untuk keluarganya.

Sebagai konsekuensi umat Islam menerima al-Qur'an dan Sunah Nabi sebagai pedoman hidup, maka untuk melaksanakan ibadah yang merupakan manifestasi imannya, umat Islam wajib berpedoman dengan al-Quran dan Sunah. ${ }^{99}$ Hanya saja kadang-kadang alQuran dan Sunah memberi tuntunan ibadah secara konkrit mengenai cara, tempat, dan waktu melakukan ibadah, misalnya ibadah haji.

Disamping itu ada beberapa ibadah yang tidak mendapat tuntunan secara konkrit didalam al-Quran dan Sunah, sehingga timbul beberapa pendapat/fatwa dari kalangan ulama/mazhab mengenai pelaksanaannya. Misalnya shalat qasar bagi orang yang sedang bepergian (musafir). ${ }^{100}$

2. Macam- macam Ibadah

Praktek ibadah sangatlah beragam, tergantung dari sudut mana kita meninjaunya.

1. Dilihat dari segi umum dan khusus, maka ibadah dibagi dua macam:

\footnotetext{
${ }^{97}$ Masjfuk Zuhdi. Studi Islam jilid II: Ibadah. (Jakarta: CV. Rajawali. 1988). 4. ${ }^{98}$ Ibid. 5.

${ }^{99}$ Masjfuk Zuhdi. Studi Islam jilid II: Ibadah. (Jakarta: CV. Rajawali. 1988). 5.

${ }^{100}$ Ibid. 6.
} 
a. Ibadah Khashah adalah ibadah yang ketentuannya telah ditetapkan dalam nash (dalil/dasar hukum) yang jelas, yaitu shalat, zakat, puasa dan haji

b. Ibadah Ammah adalah semua perilaku baik yang dilakukan semata-mata karena Allah swt seperti: bekerja, makan, minum, dan tidur sebab semua itu untuk menjaga kelangsungan hidup dan kesehatan jasmani supaya dapat mengabdi kepada-Nya

2. Ditinjau dari kepentingan perseorangan atau masyarakat, ibadah dibagi menjadi dua macam:

a. Ibadah wajib (fardhu) seperti shalat dan puasa; ${ }^{101}$

b. Ibadah ijtima'I seperti zakat dan haji;

3. Dilihat dari cara pelaksanaannya, ibadah dibagi menjadi tiga macam:

a. Ibadah jasmaniyah dan ruhiyah (shalat dan puasa)

b. Ibadah ruhiyah dan amaliyah (zakat)

c. Ibadah jasmaniyah, ruhiyah, dan amaliyah (pergi haji)

4. Ditinjau dari segi bentuk dan sifatnya, ibadah dibagi menjadi:

a. Ibadah yang berupa pekerjaan tertentu dengan perkataan dan perbuatan seperti shalat, zakat, puasa, haji

b. Ibadah yang berupa ucapan seperti membaca al-Qur'an, berdo'a dan berdzikir

c. Ibadah yang berupa perbuatan yang tidak ditentukan bentuknya seperti membela diri, menolong orang lain, mengurus jenazah, dan jihad

d. Ibadah yang berupa menahan diri seperti ihram, puasa, dan I'tikaf.

e. Ibadah yang sifatnya menggugurkan hak seperti membebaskan utang atau membebaskan utang orang lain. ${ }^{102}$

3. Hubungan Ibadah dengan Akidah dan Akhlak

Akidah adalah doktrin pokok agama Islam dan landasan ibadah, sedangkan ibadah merupakan realisasi, manifestasi, dan konsekuensi dari akidah, serta sekaligus sebagai pernyataan syukur manusia atas segala nikmat yang diterimanya dari Allah.

Ibadah harus dijiwai dan dilengkapi dengan akhlak yang mulia. Tanpa itu, ibadah orang tersebut laksana pohon yang tidak memberi naungan dan tidak pula berbuah. Artinya tidak ada manfaat ibadahnya. ${ }^{103}$ Sebagaimana pernah ditegaskan oleh Nabi Muhammad saw

\footnotetext{
${ }^{101}$ M. Pustaka. Abatasa. Macam - macam ibadah. Pustaka. http//: m.pustaka.abatasa.co.id >detail>fiqih.macammacam-ibadah.html. diakses pada rabu, 23 Maret 2016.

${ }^{102}$ Ibid.,

${ }^{103}$ Masjfuk Zuhdi. Studi Islam jilid II: Ibadah. (Jakarta: CV. Rajawali. 1988). 7.
} 
terhadap seorang wanita yang tekun melakukan ibadah puasa pada siang hari dan ibadah shalat pada malam hari, tetapi dia suka menganggu/menyakiti hati para tetangganya dengan mulutnya, bahwa "wanita tersebut akan masuk neraka". Orang yang mengaku beriman (akidah islamiyah), tetapi tidak/belum melakukan ibadah, maka ia mendapat predikat sebagai "mukmin yang 'Ashi" (orang beriman yang berdosa) atau "orang fasik". ${ }^{104}$

4. Ayat-ayat tentang Ibadah

Diantara beberapa ayat yang menjelaskan tentang ibadah adalah

Firman Allah dalam al-Qurn surat al-An'am ayat 162-63

囚8

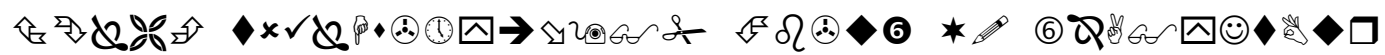

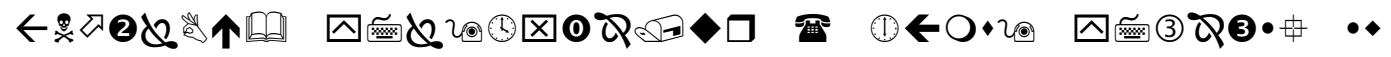

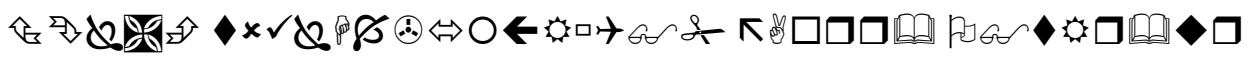

Katakanlah: Sesungguhnya sembahyangku, ibadatku, hidupku dan matiku hanyalah untuk Allah, Tuhan semesta alam.

tiada sekutu bagiNya; dan demikian Itulah yang diperintahkan kepadaku dan aku adalah orang yang pertama-tama menyerahkan diri (kepada Allah). ${ }^{105}$

Firman Allah dalam surat al-Bayyinah ayat 5

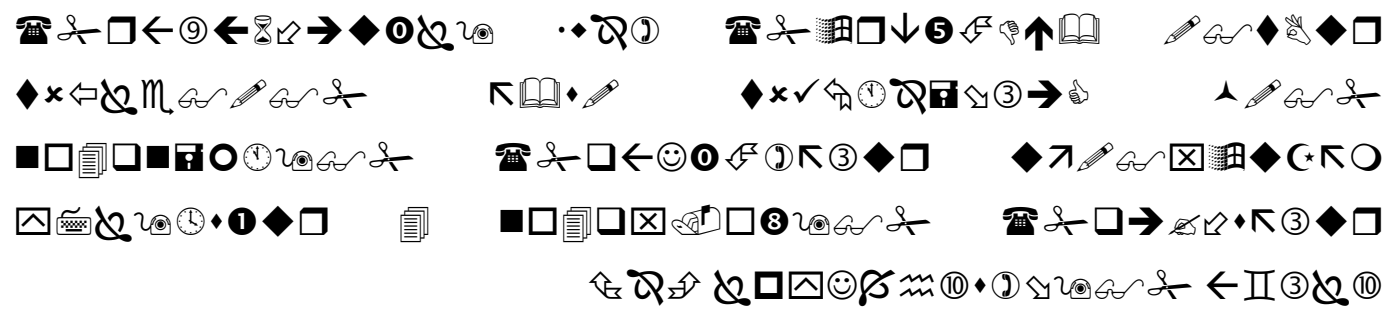

Artinya: dan mereka tidak disuruh kecuali supaya menyembah Allah dengan memurnikan ketaatan kepada-Nya dalam (menjalankan) agama yang lurus. dan supaya mereka mendirikan shalat dan menunaikan zakat; dan yang demikian Itulah agama yang lurus. ${ }^{106}$ Firman Allah swt dalam surat

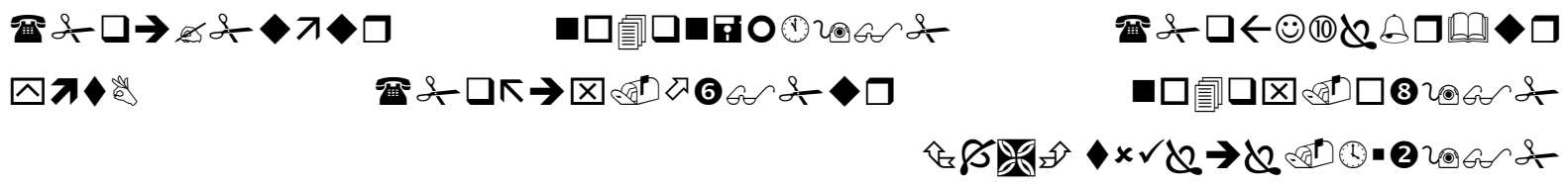

dan dirikanlah shalat, tunaikanlah zakat dan ruku'lah beserta orang-orang yang ruku'. ${ }^{107}$

\footnotetext{
${ }^{104}$ Ibid., 7

105 Departemen Agama RI, al-Qur'an dan Terjamah, ...

106 Ibid.al-Bayyinah 5

${ }^{107}$ Ibid (2): 43.
} 


\section{BAB V \\ IMAN DAN HIKMAH \\ BERIMAN KEPADA MALAIKAT}

\section{Capaian Perkuliahan}

1. Memahami penciptaan Malaikat dan tugas-tugasnya

2. Menjelaskan dengan tepat hikmah beriman kepada para malaikat

3. Mampu mendeskripsikan perbedaan antara malaikat, Jin, dan manusia

\section{A. Memahami Makna Iman kepada Malaikat dan Tugas-tugasnya}

\section{Pengertian beriman kepada Malaikat}

Iman secara bahasa artinya percaya atau yakin. Iman dari segi istilah artinya meyakini setulus hati yang mengakar kuat, mengucapkan dengan lisan, dan mengamalkan dengan seluruh anggota badan. Menurut M. Quraish Shihab, kata malaikat berasal dari bahasa Arab yaitu malä'ikah yang merupakan bentuk jamak dari kata malak yang terambil dari kata la'aka yang berarti "menyampaikan sesuatu". Jadi, malak/malaikat adalah makhluk yang menyampaikan sesuatu dari Allah Swt.. Menurut istilah, mailakat adalah makhluk gaib yang diciptakan oleh Allah Swt. dari cahaya, sebagai utusan Allah Swt. yang taat, patuh, serta tidak pernah membangkang terhadap perintahperintah-Nya. ${ }^{108}$

Iman kepada malaikat adalah meyakini dengan sepenuh hati bahwa Allah Swt. menciptakan malaikat sebagai makhluk gaib yang diutus untuk melaksanakan segala perintahNya. Orang yang mengimaninya akan senantiasa menggunakan seluruh anggota badannya untuk berhati-hati dari dalam berkata-kata dan berbuat.

\section{Hukum Beriman kepada Malaikat}

\footnotetext{
${ }^{108}$ Mustahdi dan Sumiyati. Pendidikan Agama Islam dan Budi Pekerti kelas VII, Edisi Revisi. Jakarta : Kementerian Pendidikan dan Kebudayaan. 104
} 
Beriman kepada malaikat hukumnya adalah fardlu'ain. la merupakan salah satu rukun iman selain iman kepada Allah, kitab-kitab-Nya, rasul-rasul-Nya, hari akhir, dan qada/qadar. Hal ini berdasarkan pada beberapa sumber dari al-Qur'ān dan hadis sebagai berikut:

a. firman Allah swt.dalam al-Qur'an surat al-Baqarah:285

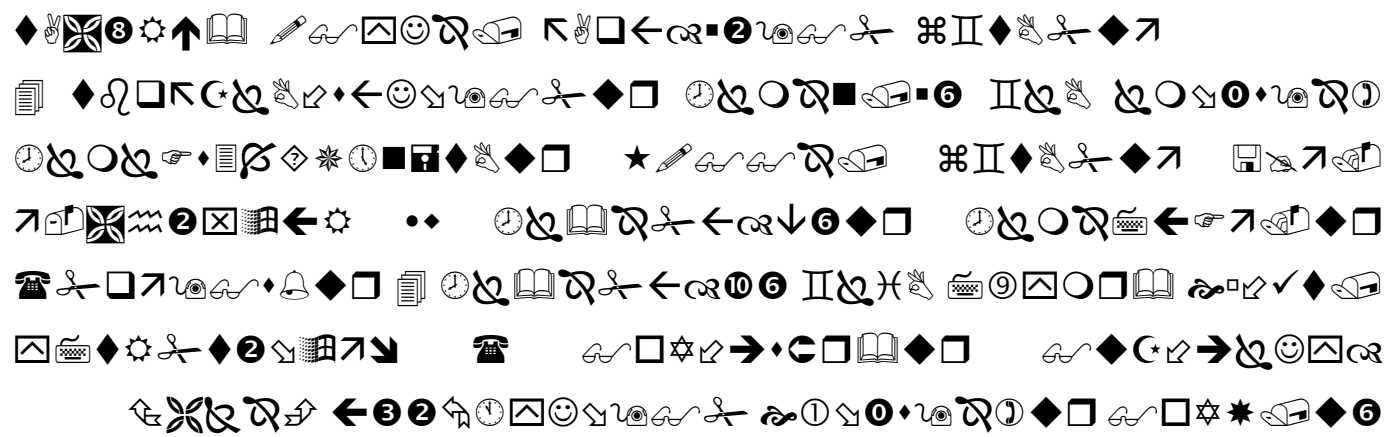

Artinya: "Rasul (Muhammad) beriman kepada apa yang diturunkan kepadanya (Al-Qurān) dari Tuhannya, demikian pula orang-orang yang beriman. Semua beriman kepada Allah, malaikatmalaikat-Nya, kitab kitab-Nya dan rasul-rasul-Nya. (Mereka berkata), “Kami tidak membedabedakan seorang pun dari rasul-rasul-Nya." Dan mereka berkata, "Kami dengar dan kami taat. Ampunilah kami, ya, Tuhan kami, dan kepada-Mu tempat (kami) kembali."

b. Hadits yang diriwayatkan oleh Bukhari dan Muslim

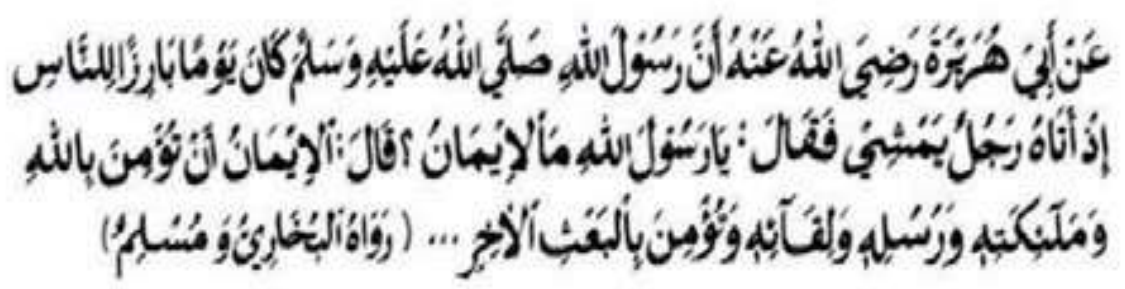

Artinya: "Diriwayatkan dari Abu Hurairah ra. bahwa pada suatu hari Rasulullah saw. muncul di tengah orang banyak, lalu beliau didatangi oleh seorang laki-laki. Orang itu bertanya, 'Wahai Rasulullah saw., apakah iman itu?' Beliau menjawab, 'Iman adalah kamu harus percaya kepada Allah Swt., malaikat-malaikat-Nya, kitab-Nya, pertemuan dengan-Nya, rasul-rasulNya, dan hari kebangkitan di akhirat nanti..." (H.R. Bukhari dan Muslim)

\section{Tentang Penciptaan Malaikat}


Mengingat sedikitnya pengetahuan yang dimiliki manusia terutama berkaitan dengan hal-hal yang gaib termasuk malaikat, sumber yang dapat dijadikan rujukan untuk mengetahui malaikat adalah dengan berpedoman kepada al-Qur'ān dan hadis-hadis Rasulullah saw. ${ }^{109}$ Dalam sebuah hadis Rasulullah saw. bersabda:

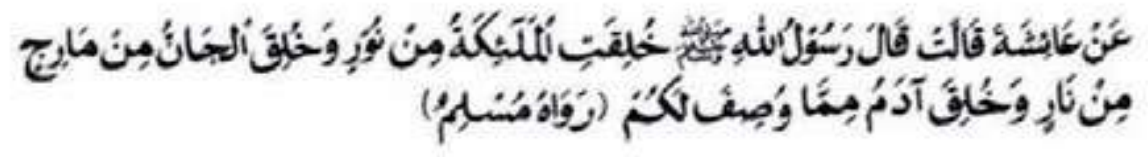

Artinya: "Dari Aisyah berkata: Rasulullah saw. bersabda, "Malaikat diciptakan dari cahaya, jin diciptakan dari api yang menyala-nyala dan Adam diciptakan dari sesuatu yang telah disebutkan (ciri-cirinya) untuk kalian." (HR.Muslim)

Keterangan lain tentang malaikat sebagaimana dijelaskan dalam Q.s Fātir ayat1

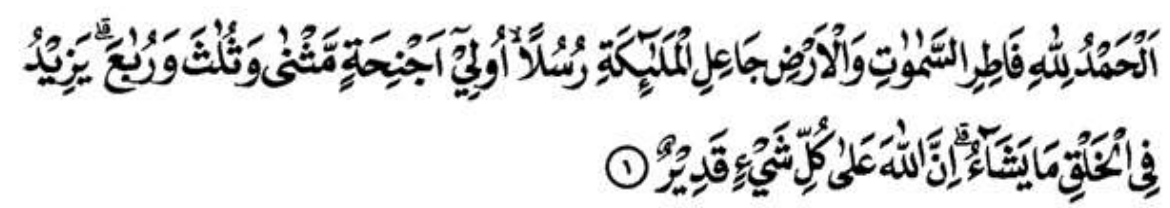

Artinya: "Segala puji bagi Allah Swt. pencipta langit dan bumi, yang menjadikan malaikat sebagai utusan-utusan (untuk mengurus berbagai macam urusan) yang mempunyai sayap, masing-masing (ada yang) dua, tiga dan empat. Allah Swt. menambahkan pada ciptaan-Nya apa yang Dia kehendaki Sungguh Allah Swt. Mahakuasa atas segala sesuatu"

Berdasarkan keterangan di atas, jelaslah bahwa malaikat adalah makhluk Allah Swt. yang diciptakan dari nur atau cahaya dan memiliki sayap, sehingga jika ada keterangan lain yang menyatakan bahwa malaikat memiliki ciri-ciri yang tidak sesuai dengan keterangan dari al-Qur'ān dan hadis, patutlah kita meragukannya.

\section{Perbedaan Malaikat dengan Manusia dan Jin}

Dari segi asal kejadian, malaikat berbeda dengan manusia dan jin, yaitu bahwa malaikat diciptakan dari nur atau cahaya sementara manusia dan jin masing-masing diciptakan dari tanah dan api. Dari sifat dan ciri-cirinya, ${ }^{110}$

${ }^{109}$ Ibid, 105

${ }^{110}$ Ibid, 106 
perbedaan malaikat, manusia, dan jin dapat dilihat dalam tabel berikut.

\begin{tabular}{|c|c|c|c|}
\hline No. & Malaikat & Jin & Manusia \\
\hline 1 & $\begin{array}{l}\text { Diciptakan dari nur } \\
\text { atau cahaya }\end{array}$ & Diciptakan dari api & Diciptakan dari tanah \\
\hline 2 & Makhluk gaib & Makhluk gaib & $\begin{array}{l}\text { Makhluk yang } \\
\text { terlihat } \\
\text { mata (kasat mata) }\end{array}$ \\
\hline 3 & $\begin{array}{l}\text { Selalu patuh dan taat } \\
\text { kepada perintah Allah } \\
\text { swt. }\end{array}$ & $\begin{array}{l}\text { Ada yang patuh dan } \\
\text { ada } \\
\text { yang durhaka } \\
\text { kepada } \\
\text { Allah swt. }\end{array}$ & $\begin{array}{l}\text { Ada yang patuh dan } \\
\text { ada yang durhaka } \\
\text { kepada Allah swt. }\end{array}$ \\
\hline 4 & $\begin{array}{l}\text { Tidak makan dan } \\
\text { tidak minum }\end{array}$ & Makan dan minum & Makan dan minum \\
\hline 5 & $\begin{array}{l}\text { Pikirannya jernih dan } \\
\text { Lurus }\end{array}$ & $\begin{array}{l}\text { Pikirannya } \\
\text { berubah-ubah }\end{array}$ & $\begin{array}{l}\text { Pikirannya } \\
\text { berubah-ubah }\end{array}$ \\
\hline 6 & $\begin{array}{l}\text { Tidak mempunyai } \\
\text { Nafsu }\end{array}$ & Mempunyai nafsu & Mempunyai nafsu \\
\hline
\end{tabular}

\section{Nama Malaikat dan Tugasnya Masing-masing}

Sebagaimana halnya manusia, para malaikat memiliki tugas. Bedanya, tugas yang diberikan Allah Swt. kepada manusia seringkali diabaikan bahkan dipertentangkan untuk dilaksanakan. Namun para malaikat, yang diberikan tugas oleh Allah Swt. kepadanya, tidak pernah menunda apalagi melalaikan dan membangkang untuk mengerjakannya. Bahkan, dia melaksanakan tugasnya sesuai dengan perintah Allah Swt. dan dia tidak mendurhakai-Nya. Allah Swt. Berfirman dalam al-Qur'an surat al-Tahrim ayat 6:

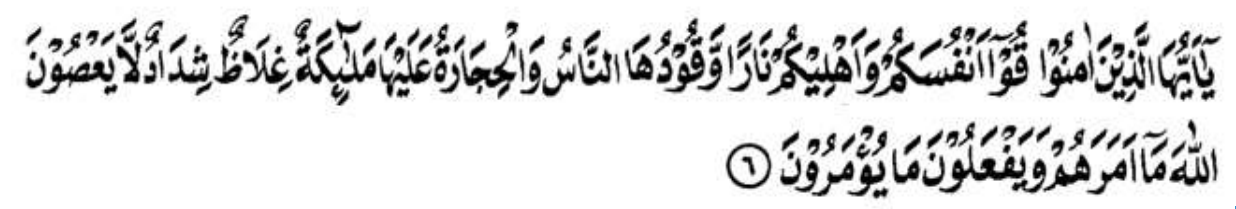

Artinya: "Wahai orang-orang yang beriman! Peliharalah dirimu dan keluargamu dari api neraka yang bahan bakarnya adalah manusia dan batu; penjaganya malaikat-malaikat yang 
kasar, dan keras, yang tidak durhaka kepada Allah Swt. terhadap apa yang Dia perintahkan kepada mereka dan selalu mengerjakan apa yang diperintahkan"

Di antara tugas-tugas malaikat itu antara lain: 1) Beribadah kepada Allah swt. dengan bertasbih kepada-Nya siang dan malam tanpa rasa bosan atau terpaksa; 2) Membawa wahyu kepada para Nabi dan para Rasul; 3) Memohon ampunan bagi orang-orang beriman; 4) Meniup sangkakala; 5) Mencatat amal perbuatan; 6) Mencabut nyawa; 7) Memberi salam kepada ahli surga; 8) Menyiksa ahli neraka; 9) Memikul 'arsy; 10) Memberi kabar gembira dan memperkokoh kedudukan kaum mukminin; dan 11) Mengerjakan pekerjaan selain yang telah disebutkan di atas ${ }^{111}$.

Penjelasan tentang nama-nama malaikat dan tugasnya masing-masing adalah sebagai berikut:

\section{Malaikat Jibril}

Malaikat Jibril dikenal juga sebagai penghulu para malaikat. la adalah satu dari tiga malaikat yang namanya disebut dalam al-Qur'ān. Nama Malaikat Jibril disebut dua kali dalam al-Qur'ān yaitu pada surat al-Baqarah/2:97-98 dan surat al-Tahrim/66:4. Malaikat Jibril memiliki beberapa nama lain atau julukan, di antaranya adalah Ruh al-Amin dan R $\mathrm{h}$ al-Qudus. Adapun tugas utamanya adalah menyampaikan wahyu dari Allah Swt. kepada para nabi dan rasul-Nya. Malaikat Jibril pula yang menyampaikan berita kelahiran Nabi Isa as. kepada ibunya Maryam dan menyampaikan al-Qur'ān kepada Nabi Muhammad saw. Dalam kisah suci perjalanan Isra' Mi'raj, sesampainya di pos perjalanan Sidratul Muntaha Malaikat Jibril tidak sanggup lagi mendampingi Rasulullah saw. untuk terus naik menghadap Allah Swt. la berkata, "Aku sama sekali tidak mampu mendekati Allah swt. Perlu waktu 60000 tahun lagi aku harus terbang untuk dapat aku capai. Jika aku terus juga ke atas, aku pasti hancur luluh". Maha suci Allah swt., ternyata Malaikat Jibril as. saja tidak sampai kepada Allah swt.

\section{Malaikat Mikail}

Malaikat Mikail adalah malaikat yang diberi tugas untuk mengatur urusan makhluk Allah swt. sekaligus mengatur rezeki terutama kepada manusia. la bertugas mengatur air, menurunkan hujan/petir, membagikan rezeki pada manusia, tumbuh-tumbuhan juga

\footnotetext{
${ }^{111}$ Mustahdi dan Sumiyati ,2014. Pendidikan Agama Islam dan Budi Pekerti kelas X, Edisi Revisi. Jakarta : Kementerian Pendidikan dan Kebudayaan. 108
} 
hewan-hewan dan lain-lain di muka bumi ini. Malaikat Mikail termasuk salah satu malaikat yang menjadi pembesar seluruh malaikat selain Malaikat Jibril. Di samping bertugas membagi rezeki dan hujan, Malaikat Mikail juga sering mendampingi Malaikat Jibril dalam menjalankan tugas-tugasnya. Diantara tugas yang pernah dilakukan bersama Malaikat Jibril adalah sebagai berikut.

a) Ketika Malaikat Jibril menjalankan tugas membelah dada Nabi Muhammad saw. untuk dicuci hatinya karena akan diisi dengan iman, islam, yakin dan sifat hilim ia mengambil peran sebagai pengambil air al-Kauiar (air zam.zam) untuk dijadikan sebagai pencuci hati Nabi Muhammad saw.

b) Ketika Nabi Muhammad saw. mendapat kepercayaan untuk melakukan Isra' dan Mi'raj, Malaikat Mikail besama Jibril ikut mendampingi selama perjalanan.

c) Malaikat Mikail juga bertugas untuk menyampaikan lembaran kepada Malaikat Maut. Dalam lembaran itu tertulis sangat detail nama, tempat, dan sebab-sebab pencabutan nyawa bagi orang yang dimaksud. ${ }^{112}$

\section{Malaikat Izrail as}

Malaikat Izrail diberi tugas mencabut nyawa semua makhluk termasuk dirinya sendiri. la dikenal juga dengan sebutan Malaikat Maut. la merupakan salah satu dari empat malaikat utama selain Jibril, Mikail, dan Israfil. Malaikat Izrail diberi kemampuan yang luar biasa oleh Allah swt., hingga barat dan timur dapat dijangkau dengan mudah olehnya seperti seseorang yang sedang menghadap sebuah meja makan yang dipenuhi dengan pelbagai makanan yang siap untuk di makan. la juga sanggup membolakbalikkan dunia sebagaimana kemampuan seseorang sanggup membolakbalikkan uang. Sewaktu Malaikat Izrail menjalankan tugasnya mencabut nyawa makhluk-makhluk dunia, ia akan turun ke dunia bersama-sama dengan dua kumpulan malaikat, yaitu Malaikat Rahmat dan Malaikat Adzab. Untuk mengetahui di mana seseorang akan menemui ajalnya, adalah tugas dari Malaikat Arham. ${ }^{113}$

\section{Malaikat Israfil}

Malaikat Israfil diberi tugas meniup sangkakala. Israfil selalu memegangterompet suci yang terletak di bibirnya selama berabad-abad, menunggu perintah dari Allah Swt.

\footnotetext{
${ }^{112}$ Ibid 110

${ }^{113}$ Imam Abdirrahim Bin Ahmad Al-Qadhiy, 2003. Rahasia Alam Ghaib Dan Alam Akhirat (Terjemah Daqqoiqul Akhbar). Surabaya : Ampel Mulia. 11
} 
untuk meniupnya pada hari kiamat. Pada hari itu ia akan turun ke bumi dan berdiri di batu/bukit suci di Jerusalem. Tiupan pertama akan menghancurkan dunia beserta isinya, tiupan kedua akan mematikan para malaikat dan tiupan ketiga akan membangkitkan orangorang yang telah mati dan mengumpulkan mereka di Padang Mahsyar.

Di dalam kitab Tanbihul Gāfilin Jilid 1 halaman 60 ada sebuah hadis panjang yang menceritakan tentang kejadian kiamat yang pada bagian awalnya sangat menarik untuk dicermati. Abu Hurairah ra. berkata: Rasulullah saw. bersabda, "Ketika Allah Swt. telah selesai menjadikan langit dan bumi, Allah Swt. menjadikan sangkakala (terompet) dan diserahkan kepada Malaikat Israfil, kemudian ia letakkan di mulutnya sambil melihat ke Arsy menantikan bilakah ia diperintah". Saya bertanya: "Ya Rasulullah saw. apakah sangkakala itu?" Jawab Rasulullah saw. "Bagaikan tanduk dari cahaya." Saya tanya; "Bagaimana besarnya?" Jawab Rasulullah saw.; "Sangat besar bulatannya, demi Allah Swt. Yang mengutusku sebagai Nabi, besar bulatannya itu seluas langit dan bumi, dan akan ditiup hingga tiga kali. Pertama: Nafkhatul fazā' (untuk menakutkan). Kedua: Nafkhatus sa'aq (untuk mematikan). Ketiga: Nafkhatul ba'ats (untuk menghidupkan kembali atau membangkitkan)." Dalam hadis di atas, disebutkan bahwa sangkakala atau terompet Malaikat Israfil itu bentuknya seperti tanduk dan terbuat dari cahaya. Ukuran bulatannya seluas langit dan bumi. Bentuknya laksana tanduk mengingatkan kita pada terompet orang-orang zaman dahulu yang terbuat dari tanduk. ${ }^{114}$

\section{5/6. Malaikat Munkar \& Nakir}

Malaikat Munkar diberi tugas untuk bertanya kepada orang yang sudah mati di alam kubur bersama Malaikat Nakir. Malaikat Munkar dan Malaikat Nakir adalah dua malaikat yang bertugas menanyakan dan menguji iman orang yang sudah mati di alam kubur. Pemeriksaan akan dimulai ketika pemakaman selesai dan orang terakhir dari jamaah pemakaman telah melangkah 40 langkah dari kuburan. Malaikat Munkar dan Malaikat Nakir menanyakan tiga pertanyaan: "Siapa Tuhanmu? Siapa nabimu? Apa agamamu? Apa kitabmu? Dimana kiblatmu? Siapa saudaramu?". Seorang mukmin yang saleh akan merespons dengan benar, mengatakan bahwa Tuhan mereka adalah Allah Swt., Muhammad adalah nabi mereka, agama mereka adalah Islam, al-Qur'ān adalah kitab mereka, Ka'bah adalah kiblat mereka, dan muslimin dan muslimat adalah saudara mereka. Jika jawaban benar, waktu yang dihabiskan untuk menunggu hari kebangkitan adalah

114 ibid. 61 
menyenangkan. Mereka yang tidak menjawab seperti yang dijelaskan di atas dihukum sampai hari penghakiman. ${ }^{115}$

\section{Malaikat Raqib}

Malaikat Raqib bertugas mencatat segala amal kebaikan manusia. la bersama Malaikat 'Atid yang mencatat amal buruk berjalan beriringan. (Q.S. Qāf/50:18). Dari Anas ra., dari Nabi Muhammad saw., Sabdanya: "Sesungguhnya Allah swt. telah menugaskan dua malaikat untuk menulis segala apa yang dilakukan atau dituturkan oleh seseorang hamba-Nya (satu di sebelah kanannya dan yang satu lagi di sebelah kirinya); kemudian apabila orang itu mati, Tuhan perintahkan kedua malaikat itu dengan firman-Nya, "Hendaklah kamu berdua tinggal tetap di kubur hamba-Ku itu serta hendaklah kamu mengucap tasbih, tahmid dan takbir hingga ke hari qiamat dan hendaklah kamu menulis pahalanya untuk hamba-Ku itu." (H.R. Abu al-Syeikh dan Tabrani)

\section{Malaikat 'Atid}

Malaikat 'Atid adalah bertugas mencatat segala amal keburukan manusia. Kedua malaikat ini (Raqib dan 'Atid) sangat jujur dan tak pernah bermaksiat kepada Allah swt. Mereka mencatat dengan penuh ketelitian, sehingga tidak ada satu pun keburukan dan kebaikan yang luput dari catatan keduanya. Mereka tidak ditugaskan untuk mengolah, menganalisis, menyimpulkan apalagi menjatuhkan vonis. Mereka hanya menyetor data, semua keputusan ada pada Maha kasih-sayang Allah swt.

\section{Malaikat Malik}

Malaikat Malik adalah pemimpin malaikat yang bertugas di neraka. Malaikat Malik disebut dalam Q.S. Az-Zukhruf/43 :77:

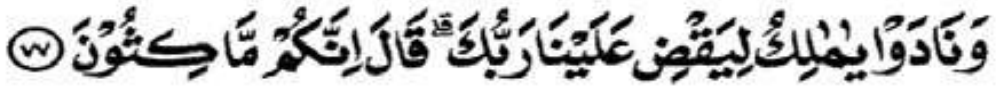

Artinya : "Dan mereka berseru, "Wahai (Malaikat) Malik! Biarlah Tuhan-mu mematikan kami saja." Dia menjawab, "Sungguh, kamu akan tetap tinggal (di neraka ini)." (Q.S. az-Zukhruf/43:77)

${ }^{115}$ Ibid, 48 
Dari ayat di atas, dapat dipahami bahwa Malaikat Malik adalah pemimpin malaikat yang bertugas di neraka. Hal ini dipertegas oleh firman Allah swt yang artinya, " $D i$ atasnya ada sembilan belas (malaikat penjaga)".(Q.S. al-Muddatsir/74:30)

\section{Malaikat Ridwan}

Malaikat Ridwan diberi tugas menjaga dan mengawasi surga serta menyambut semua hamba Allah swt. yang akan masuk ke dalamnya. la sangat ramah menyambut dan mempersilahkan orang-orang yang akan masuk ke dalam surga.

\section{B. Hikmah Beriman kepada Malaikat}

Orang-orang yang beriman selalu dapat mengambil pelajaran dari apa yang diimani. Dalam hal beriman kepada malaikat-malaikat Allah swt., pelajaran yang dapat dipetik antara lain seperti berikut:

a) Menambah keimanan dan ketakwaan kepada Allah swt.

b) Senantiasa hati-hati dalam setiap ucapan dan perbuatan sebab segala apa yang dilakukan manusia tidak luput dari pengamatan malaikat Allah swt.

c) Menambah kesadaran terhadap alam wujud yang tidak terjangkau oleh pancaindra.

d) Menambah rasya syukur kepada Allah swt. karena melalui malaikat-malaikat-Nya, manusia memperoleh banyak karunia.

e) Menambah semangat dan ikhlas dalam beribadah walaupun tidak dilihat oleh orang lain ketika melakukannya.

f) Menumbuhkan cinta kepada amal saleh karena malaikat selalu siap mencatat amal manusia.

g) Semakin giat dalam berusaha karena tidak ada rizki yang diturunkan oleh malaikat Allah swt. tanpa melalui usaha dan kerja keras ${ }^{116}$.

${ }^{116}$ Mustahdi dan Sumiyati ,2014. Pendidikan Agama Islam dan Budi Pekerti kelas VII, Edisi Revisi. Jakarta : Kementerian Pendidikan dan Kebudayaan.112 


\section{BAB VI}

\section{WAQAF DAN ZAKAT}

\section{Capaian Perkuliahan}

1. . .......

2. $\ldots . .$.

3.

\section{Gambar 1.11}

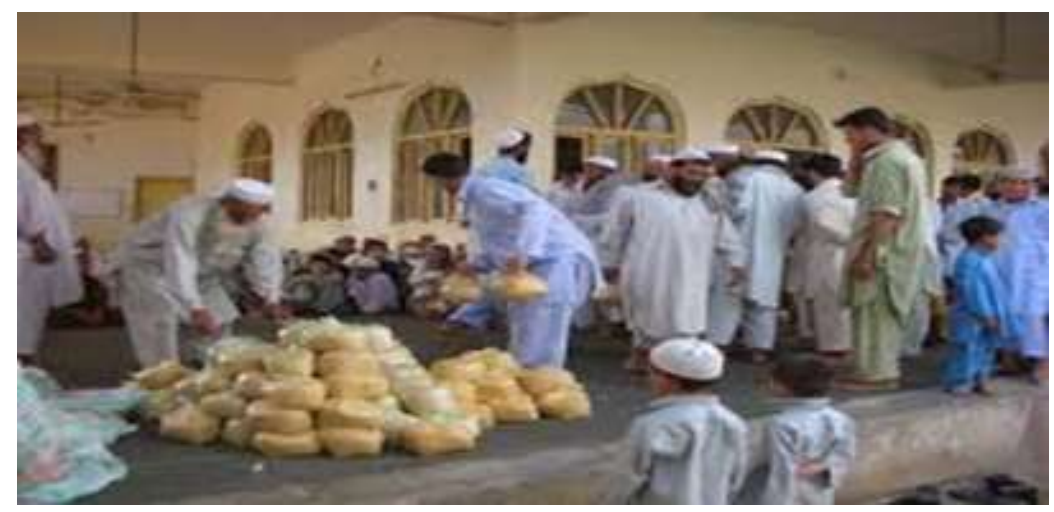

A. Pengertian Wakaf

Wakaf berasal dari bahasa arab al-Waqf telah dipakai sebagai salah satu peristilahan perundang-undangan di Indonesia. Kata al-Waqf sama artinya dengan al-habs dan al-tasharruf atau penahanan dari memakainya, yakni seseorang menahan harta yang di milikinya dan tidak memakai dan serta tidak memindahkan kepemilikannya. Secara sederhana dapat pula dikatakan bahwa wakaf menurut bahasa berarti menahan harta, tidak dipakai oleh pemiliknya, tidak pula diizinkannya untuk dipindah milikkan. ${ }^{117}$

Dalam merumuskan pengertian wakaf, para ulama figh tidak memiliki kata sepakat. Menurut jumhur ulama, wakaf ialah sebagai kegiatan penahanan harta yang berkemungkinan bermanfaat oleh pemilikknya dengan membiarkan ainnya tetap kekal dan tidak dipindahmilikkan kepada kaum kerabatnya atau kepada pihak lain.

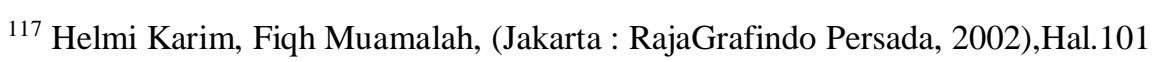


Ulama hanafiah mengatakan bahwa wakaf adalah membiarkan harta seseorang itu tetap menjadi hak miliknya serta menyedekahkan manfaat harta itu untuk kebajikan, sedangkan ulama malikiyah berpendapat bahwa wakaf adalah penahanan sesuatu hak milik supaya ia tetap menjadi milik pihak yang berwakaf sambil menyedekahkan hasil-hasilnya.

Terdapat perbedaan rumusan tersebut pada dasarnya diakibatkan oleh pendapat masing-masing tentang status harta wakaf di belakang hari, yakni tentang apakah harta itu akan bersifat tetap menjadi milik yang berwakaf atau bisa dipindahkan hak miliknya atau diwariskan. Namun demikian, terlepas dari bisa atau tidaknya harta wakaf ditarik kembali, definisi-definisi tersebut menunjukkan suatu pandangan yang sama bahwa wakaf adalah penahanan pemindahan harta suatu hak milik oleh pihak yang berwakaf dan menyedekahkan segala manfaat dan hasil yang bisa diambil dari harta tersebut untuk kebajikan dalam rangka mencari keridhaan Allah swt. Dalam kerangka ini, sayyid Sabiq lantas merumuskan bahwa wakaf adalah penahanan harta dan mengambil manfaat dari harta yang ditahan itu untuk jalan Allah swt, atau menahan harta yang mungkin bisa diambil manfaatnya tanpa merusak atau menghabiskan ain benda itu sendiri serta digunakan untuk tujuan kebajikan.

\section{B. Hukum Wakaf}

Al-Qur'an tidak pernah berbicara secara spesifik dan tegas tentang wakaf. Hanya saja, karena wakaf itu merupakan salah satu bentuk kebajikan melalui harta benda, maka para ulama pun memahami bahwa ayat-ayat al-Qur'an yang memerintahkan pemanfaatan harta untuk kebajikan juga mencakup kebajikan melalui wakaf. Karena itu di dalam kitab-kitab fiqih ditemukan pendapat yang mengatakan bahwa dasar hukum wakaf disimpulkan dari beberapa ayat, seperti :

1. Firman Allah dalam surat Ali Imran ayat 92 :

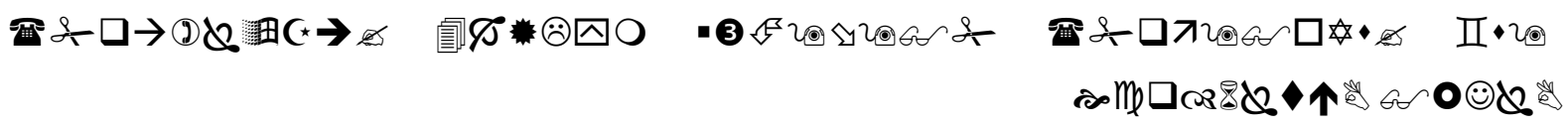

Artinya: kamu sekali-kali tidak sampai kepada kebajikan (yang sempurna), sebelum kamu menafkahkan sehahagian harta yang kamu cintai.

2. Firman Allah dalam surat al-Baqarah ayat 267 :

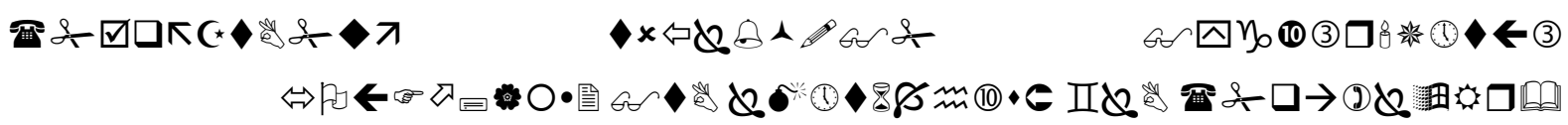

"Hai orang-orang yang beriman, nafkahkanlah (di jalan Allah) sebagian dari hasil usahamu yang baik-baik".

Para ulama menilai bahwa wakaf itu termasuk kategori sedekah jariyah yang nilai pahalanya senantiasa mengalir selagi manfaatnya bisa dipetik. Dalam konteks inilah maka para 
fukaha mengemukakan hadis Nabi Muhammad saw yang berbicara tentang keutamaan sedekah jariah sebagai salah satu sandaran wakaf. Diriwayatkan oleh Abu Hurairah : " Bahwa Rasulullah saw telah bersabda : apabila manusia meninggal maka terputuslah segala amalnya kecuali tiga macam, yaitu sedekah jariah,ilmu yang yang bermanfaat, atau anak sholeh yang selalu mendoakannya. ${ }^{118}$

Para ulama berpendapat bahwa hukum berwakaf itu dianjurkan oleh agama, sebab padanya merupakan salah satu bentuk kebajikan. Jadi, salah satu bentuk kebajikan harta ialah dengan jalan berwakaf, sebab orang lain akan mendapat manfaat dari harta yang diwakafkan itu.

Dilihat dari segi sasarannya, pada dasarnya wakaf dapat dibagi kepada dua bentuk. Pertama, wakaf yang diberikan kepada keluarga dan karib kerabat atau orang-orang ertentu yang disebut dengan wakaf al-ahliy atau wakaf al-dzurriy. Sasaran wakaf jenis ini adala pribadi tertentu atau masyarakat yang memotivasinya bukan untuk memajukan agama islam. Jenis wakaf kedua adalah wakaf untuk kebajikan dalam rangka mendekatkan diri kepada Tuhan yang disebu dengan wakaf al-khairiy. Mewakafkan sebidang tanah untuk masjid, umpamanya, termasuk ke dalam jenis wakaf yang terakhir ini. Wakaf al-khairiy inilah yang paling disukai, dan jenis ini pula yang banyak berlaku di Indonesia.

\section{Rukun dan Syarat Wakaf}

Untuk terwujudnya wakaf, terdapat rukun-rukun yang harus terpenuhi dan ada pula syarat rukun-rukun tersebut. Rukun wakaf ada empat :

1. Pihak yang berwakaf (wakif)

2. Benda yang diwakafkan (mawquf)

3. Sasaran wakaf (mauwquf 'alaih)

4. Shighat wakaf. ${ }^{119}$

Adapun persyaratan masing-masing rukun itu adalah :

1. Pihak yang berwakaf merupakan salah satu rukun wakaf mestilah ada. Tidak mungkin ada wakaf apabila tidak ada pihak yang berwakaf. Syarat orang yang berwakaf adalah :

a) Orang yang berwakaf itu mestilah sudah mempunyai kecakapan bertindak yang sempurna sehingga ia boleh mentabarru' kan hartanya, yaitu sudah dipandang pantas dan patut untuk melakukan tindakan terhadap hartanya, yaakni sudah balik dan berakal sempurna.

b) Tidak dalam keadaan dipaksa atau terpaksa

118 Fiqh Muamalah, Helmi Karim, (Jakarta : PT.RajaGrafindo Persada, 2002),Hal. 104

${ }^{119}$ Fiqh Muamalah, Helmi Karim, (Jakarta : PT.RajaGrafindo Persada, 2002), Hal. 108 
c) Orang yang berwakaf disyaratkan sebagai pemilik sah dari harta yang diwakafkannya.

2. Benda yang diwakafkan, adalah salah satu rukun wakaf. Benda itu haruslah memenuhi persyaratan sebagai berikut :

a) Benda itu mestilah milik sah dari pihak yang berwakaf

b) Benda yang diwakafkan itu mestilah tahan lama dan bisa diambil manfaatnya.

c) Benda yang diwakafkan mestilah sesuatu yang boleh dimiliki dan dimanfaatkan. Karena itu tidak boleh mewakafkan seekor babi atau bendaObenda lainnya kepada umat islam.

3. Sasaran wakaf, yakni wakaf yang diberikan haruslah jelas sasarannya. Dalam hal ini ada dua sasaran wakaf :

a) Wakaf untuk mencari keridhaan Allah. Wakaf jenis ini tujuannya adalah untuk memajukan agama islam atau karena motivasi agama.

b) Wakaf untuk meringankan atau untuk membantu seseorang atau orang tertentu atau masyarakat bukan karena motivasi agama. Contohnya adalah berwakaf untuk fakir miskin atau berwakaf untuk keluarga. Dalam hal ini yang perlu di garis bawahi ialah bahwa wakaf tidak boleh dilakukan untuk hal-hal yang bertentangan dengan kepentingan agama islam. ${ }^{120}$

4. Shighat wakaf atau ikrar wakaf, yakni berupa ucapan yang menunjukkan adanya wakaf. Sighat yang dipakai adalah kata-kata yang menunjukkan adanya wakaf walaupun tidak harus deangan redaksi "wakaf". Tentu saja yang paling diutamakan adalah kata wakaf, sehingga dengan mudah bisa ditangkap makna dari ikrar wakaf itu.

\section{Pengertian Zakat}

Perkataan zakat ditinjau dari bahasa, berasal dari kata dasar (masdar) "zakâ" yang berarti berkah, tumbuh, bersih, baik dan bertambah. ${ }^{121}$

Jika diucapkan "Zakat al-Nafaqoh" artinya nafkah tumbuh dan bertambah jika di berkati. Kata ini juga sering dikemukakan untuk makna " thaharoh"(suci). Allah SWT berfirman al-Syams ayat 9:

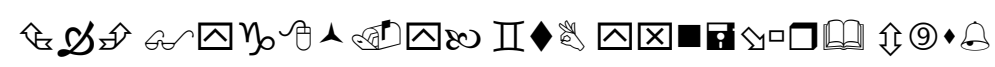

"Sesungguhnya beruntunglah orang yang mensucikan jiwa itu".

Arti "tumbuh" dan "suci" tidak dipakaikan hanya buat kekayaan, tetapi lebih dari itu juga buat jiwa orang yang menzakatkannya, sesuai dengan firman Allah SWT:

${ }^{120}$ Fiqh Muamalah, Helmi Karim, (Jakarta : PT.RajaGrafindo Persada, 2002), Hal. 110

${ }^{121}$ R. Soegarda Poerbakawatja, Ensiklopedi Islam,(Jakarta: Ichtiar Baru Van Hoeve, 1999), Cet I, hlm 224 


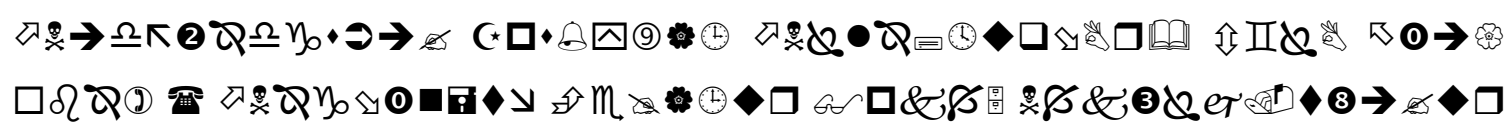

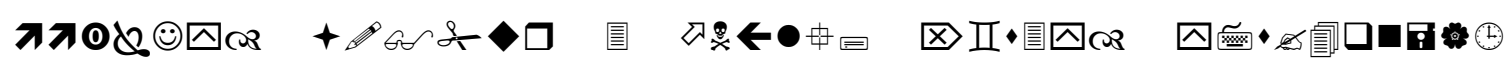

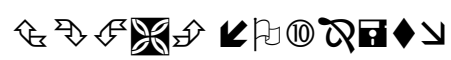

Artinya : "Ambillah zakat dari sebagian harta mereka, dengan zakat itu kamu membersihkan dan mensucikan mereka dan mendoalah untuk mereka. Sesungguhnya doa kamu itu menjadi ketenteraman jiwa bagi mereka. dan Allah Maha mendengar lagi Maha mengetahui.

Maksudnya: zakat itu membersihkan mereka dari kekikiran dan cinta yang berlebihlebihan kepada harta benda, dan zakat itu menyuburkan sifat-sifat kebaikan dalam hati mereka dan memperkembangkan harta benda mereka.

Pengertian zakat menurut syara', berarti adalah hak dan wajib di keluarkan dari harta. Madhab Maliki mendefinisikannya dengan “ Mengeluarkan sebagian yang khusus dari harta yang khusus pula yang telah mencapai nishab (batas kuantitas yang mewajibkan zakat) kepada orang orang yang berhak menerimanya. Dengan catatan kepemilikain itu penuh dan mencapai haul (setahun), bukan barang tambang dan bukan pertanian. ${ }^{122}$

Madhab Hanafi mendefinisikan zakat dengan, "menjadikan sebagian harta yang khusus sebagai milik orang yang khusus", yang ditentukan oleh syariat karena Allah swt. Menurut Madhab Syafi'i, zakat sesuai dengan cara khusus. Sedangkan menurut madhab Hambali, zakat ialah hak yang wajib (dikeluarkan) dari harta yang khusus untuk kelompok yang khusus pula.

Dari berbagai definisi di atas, jelaslah dapat ditarik satu kesimpulan bahwa kata zakat dalam pandangan fuqaha, dimaksudkan sebagai "penunaian", yakni penunaian hak dan wajib, yang terdapat dalam harta, juga dimaksudkan sebagai bagian harta tertentu dan yang diwajibkan Allah swt untuk diberikan kepada orang-orang fakir. Zakat dinamakan shadaqah karena tindakan itu akan menunjukkan kebenaran (shidiq) seorang hamba dalam beribadah dan melakukan ketaatan kepada Allah swt.

E. Sejarah Zakat

Perintah wajib zakat turun di Madinah pada bulan Syawal pada tahun keduan hijrah Nabi saw. Kewajibannya terjadi setelah kewajiban puasa Ramadhan dan zakat fitrah. Zakat mulai diwajibkan di Madinah karena masyarakat Islam sudah mulai terbentuk, dan kewajiban ini dimaksudkan untuk membina masyarakat muslim yakni sebagai bukti solidaritas sosial, dalam arti

122 Dahlan, Abdul Aziz, Ensiklopedi Hukum Islam, (Jakarta: Ichtiar Baru van Hoeve, 1996), hlm. 1985 
bahwa orang kaya yang berzakat yang patut masuk dalam barisan kaum beriman. Adapun ketika umat Islam masih berada di Makkah. Allah swt, sudah menegaskan dalam al-Qur'an tentang pembelanjaan harta yang belum dinamakan zakat, tetapi berupa kewajiban infaq, yaitu bagi mereka yang mempunyai kelebihan wajib membantu yang kekurangan, besarnya tergantung kepada kerelaan masing-masing, yang tentunya kerelaan itu berkaitan erat dengan kualitas iman yang bersangkutan. ${ }^{123}$

Selama 13 tahun di Makkah, kaum muslimin didorong untuk menginfakkan harta mereka buat fakir, miskin, budak, namun sebelum ditentukan nishab dan berapa kewajibannya zakatnya, juga belum diketahui apakah telah diorganisasi pengumpulan dan penyalurannya. Dan syara' hanya menyuruh mengeluarkan zakat. Banyak sedikitnya terserah kepada kemauan dan keridlaan para penzakat sendiri. Yang jelas, kaum muslimin awal memberikan sebagian harta mereka untuk kepentingan Islam. Abu Bakar r.a. misalnya, memerdekakan sejumlah budak setelah membeli mereka dengan harga mahal. ${ }^{124}$

Periode Madinah ditentukan nishab dan jumlah kewajiban zakat administrasi, pengumpulan dan penyalurannya. Zakat turun di madinah memberikan rincian sistematik tentang kewajiban zakat. Bahkan ceramah Rasulullah di madinah setelah hijrah berisi juga kewajiban zakat dan Infaq. Rasulullah pernah mengirim Ala al-Hadrami ke Bahrain dan Amr ke Oman pada tahun $8 \mathrm{H}, \mathrm{Muadz}$ ke Yaman pada tahun $9 \mathrm{H}$.

Dalam banyak riwayat dikisahkan bahwa, zakat dari suatu daerah disalurkan ke daerah itu juga, tidak dibawa ke Madinah. Meski demikian, beberapa riwayat mengisahkan sebagian zakat ada juga yang dikirim ke Madinah. Konsep zakat tidak statis, tapi terus dikembangkan oleh Khulafaur Rasyidin dan para ulama' setelahnya.

Dalam soal manajemen, pada awal Islam, ada pengalaman yang menarik bahwa zakat dikelola oleh pemerintah. Pendapat ini memang dapat diperdebatkan. Sejarah mencatat bahwa sejak Rasulullah saw melakukan migrasi atau hijrah dari Makkah ke Madinah, beliau di posisikan sebagai Nabi dan Negarawan. Dengan demikian, keberadaan beliau selain pemimpin agama, juga sebagai pemimpin negara dan pemerintahan. Tidak salah jika ada orang yang berpendapat bahwa Islam adalah agama dan negara (al-Islam huwa al-din wa al-daulah).

Ibadah zakat dapat dipertanggung jawabkan kepada pemerintah, karena dalam pengamalannya lebih berat di banding ibadah-ibadah yang lain. Dengan demikian asas ikhlas dan

\footnotetext{
${ }^{123}$ Muhammad, Zakat Profesi Wacana pemikiran dalam Fiqih Kontemporer, (Jakarta: Salemba Diniyah, 2002), hlm 16.

${ }^{124}$ T.M. Hasbi Ash Shiddieqy, Pedoman Zakat, ( Jakarta : PT. Bulan Bintang , 1897 ), hlm, 31.
} 
sukarela tetap dominan dalam pelaksanaan dan penerapan zakat sebagaimana yang berlaku pada masa Rasulullah, Khulafaur al-Rasyidin dan pemerintahan Islam dibelakangnya.

Gambar.1.12

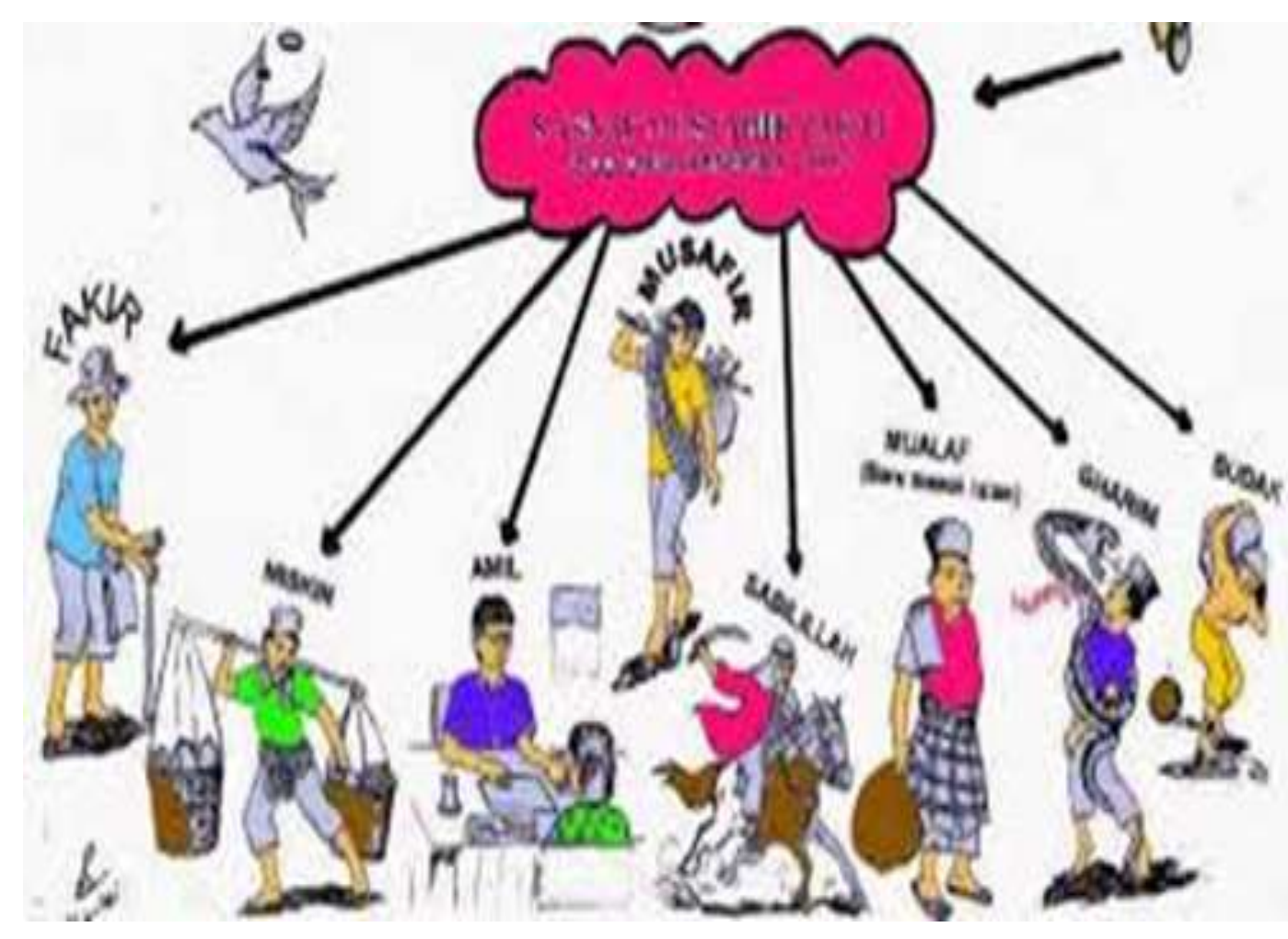

F. Perintah Zakat

Zakat sebagai ibadah Maliyah ljtima'iyah (ibadah yang berkaitan dengan ekonomi keuangan dan kemasyarakatan), merupakan salah satu rukun Islam yang mempunyai status dan fungsi yang penting dalam syariat Islam. Kata zakat dalam bentuk ma'rifat disebut pada 32 ayat dalam Al-Qur'an yang diantaranya 26 kali dalam Al-Qur'anmenegaskan kewajiban zakat bersamaan kewajiban shalat. salah satunya ialah Surat Al-Baqarah ayat 110 :

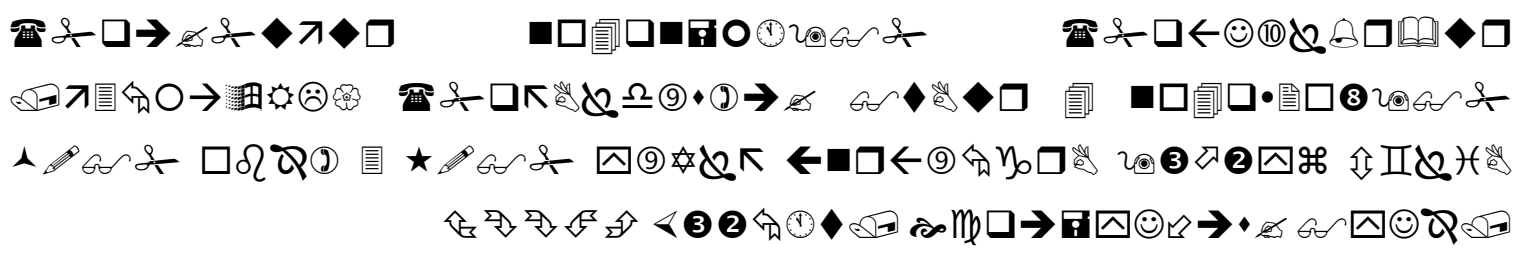

Artinya :"Dan dirikanlah shalat dan tunaikanlah zakat. dan kebaikan apa saja yang kamu usahakan bagi dirimu, tentu kamu akan mendapat pahala nya pada sisi Allah. Sesungguhnya Alah Maha melihat apa-apa yang kamu kerjakan".

Adapun dalil-dalil yang menjadi dasar wajibnya zakat dalam Al-Qur'an diantaranya adalah firman Allah SWT: 


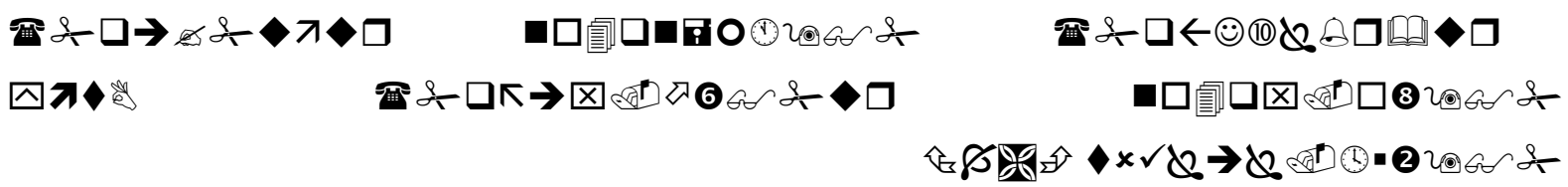

Artinya :dan dirikanlah shalat, tunaikanlah zakat dan ruku'lah beserta orang-orang yang ruku'. ${ }^{125}$

Dan juga hadist Nabi saw yang diriwayatkan Imam Muslim dari Ibnu Umar. Hadist tersebut berbunyi: Dari Ibnu Umar r.a. Bahwa Rasulullah saw telah bersabda: Islam didirikan dari lima sendi yaitu: mengaku bahwa tidak ada Tuhan yang sebenarnya disembah melainkan Allah dan bahwasannya Muhammad itu utusan Allah, mendirikan sholat, mengeluarkan zakat dan puasa di bulan Ramadhan.

Selain ayat-ayat Al-Qur'an dan Hadits Nabi saw yang disebutkan di atas, masih banyak lagi ayat dan hadits yang menjelaskan kewajiban mengeluarkan zakat, dan bahwa zakat adalah salah satu rukun Islam yang wajib dilaksanakan oleh oleh orang yang mengaku beragama Islam.

Zakat diwajibkan atas orang Islam dan merdeka yang memiliki senisab harta secara sempurna. Sebagaian ulama mengecualikan anak-anak dan orang gila, dengan alasan bahwa zakat termasuk ibadah seperti halnya shalat, sedangkan mereka bukan orang yang dibebani kewajiban ibadah. Namun, Syafi'i dan Jumhur ulama berpendapat bahwa harta anak-anak dan orang gila juga dikenai zakat dengan berbagai alasan. Pertama, bahwa yang dimaksud zakat itu itu pahala bagi yang berzakat dan memberi jalan bagi orang fakir. Anak-anak dan orang gila dapat memperoleh pahala, dan termasuk pemberi belanja yang menanggung nafkah kerabatnya. Kedua, hadis yang menerangkan bahwa Rosulullah bersabda : "berusahalah pada harta anak yatim, agar harta itu tidak termakan oleh zakat". ${ }^{126}$

\section{G. FUNGSI ZAKAT}

Fungsi zakat adalah sebagai berikut:

a. Membersihkan harta (kekayaan)

Orang mukmin diperintahkan makan dari barang yang halal. Hal itu berarti dalam memperoleh harta harus halal. Bagi orang kaya, ada harta yang merupakan hak/bagian fakir miskin. Apabila hak itu tidak diberikan, harta itu bercampur dengan yang tidak halal. Allah SWT berfirman sebagai berikut:

"Ambillah zakat dari sebagian harta mereka, dengan zakat itu kamu membersihkan dan menyucikan mereka dan berdoalah untuk mereka. Sesungguhnya doa kamu itu (menjadi)

${ }_{125}^{125}$ QS. Al-Baqarah/2 :43

126 Supiana, M. Kamal, Materi Pendidikan Agama Islam, ( Bandung : PT.Rosdakarya, 2004), Hal. 62 
ketentraman jiwa bagi mereka. Dan AllahMaha Mendengar lagi Maha Mengetahui. (QS. AtTaubah:103)

b. Mendidik sifat dermawan

Bakhil termasuk penyakit hati maka harus dihilangkan. Ada ayat yang menerangkan bagaimana keikhlasan orang-orang Anshar dalam bersedekah sehingga mereka terhindar dari kebakhilan. Firman Allah SWT sebagai berikut:“... dan mereka mengutamakan (orang-orang muhajirin) atas diri mereka sendiri, sekalipun mereka dalam kesusahan. Dan siapa yang dipelihara dari kekikiran dirinya, mereka itulah orang-orang yang beruntung. ${ }^{127}$

c. Merupakan salah satu wujud syukur

Syukur dapat diwujudkan dengan ucapan atau perbuatan anggota badan dan harta. Orang yang dianugerahi harta banyak wajib membayar infak, zakat, ataupun sedekah sebagai rasa syukur kita kepada Allah dan mengharap pahala dari-Nya.

Allah SWT berfirman sebagai berikut:

Sesungguhnya orang-orang yang beriman, mengerjakan amal saleh, mendirikan salat, dan menunaikan zakat. Mereka mendapat pahala di sisi Tuhannya. Tidak ada kekhawatiran terhadap mereka dan tidak (pula) mereka bersedih hati. (QS. AI-Baqarah:277)

d. Merupakan sarana penyantunan fakir miskin

Setiap orang mempunyai hak hidup dan kehidupan. Orang Islam yang kaya harus memikirkan dan mengusahakan saudaranya agar terlepas dari kemiskinan. Jika kita mengingat bahwa orang yang sehari tidak makan menderita sekali, dan kita diam saja, maka akan sangat tercela bagi yang mengabaikannya. Oleh karena itu, orang yang memupuk kekayaan tanpa batasdan tidak diinfakkan pada jalan Allah diancam oleh Allah, seperti dalam firman-Nya berikut ini:

“... dan orang-orang yang menyimpan emas dan perak dan tidak menafkahkannya pada jalan Allah maka beritahukanlah kepada mereka ,(bahwa mereka akan mendapat) siksa yang pedih, pada hari dipanaskan emas dan perak itu dalam neraka jahanam, lalu dibakar dengan dahi mereka, lambung dan punggung mereka (lalu dikatakan) kepada mereka: " inilah harta bendamuyang kamu simpan untuk dirimu sendiri maka rasakanlah sekarang (akibat dari) apa yang kamu simpan. ${ }^{128}$

Sehubungan dengan ayat tersebut, Rasulullah saw. bersabda: Dari Abi Hurairah, Rasulullah saw. bersabda: "Seseorang yang menyimpan hartanya tidak dikeluarkan zakatnya

${ }^{127}$ QS.Al-Hasyr: 9

${ }^{128}$ QS. At-Taubah: 34-35 
akan dibakar dalam neraka jahanam, baginya dibuatkan setrika api kemudian disetrika lambungnya dan keningnya."(HR.Ahmad dan Muslim)

e. Merupakan sarana lahirnya masyarakat yang terhormat

Zakat diharapkan dapat mengurangi gelandangan dan pengemis. Setiap desa didata keadaan masyarakat yang hidupnya kurang memenuhi syarat. Dengan data itu dapat diketahui berapa jumlah pengemis, tuna wisma, dan sebagainya.

Selanjutnya, badan amil zakat memperhitungkan kekayaan umat Islam dan menentukan tabel zakat masing-masing, kemudian membagikan zakat kepada mereka yang berhak menerimanya. Dari zakat itu, umat Islam akan menjadi makmur. Apabila umat Islam tidak mampu membiayai umatnya sendiri, tidak menutup kemungkinan warganya akan disantuni oleh umat lain.

\section{H. TUJUAN ZAKAT}

Tujuan Zakat adalah salah satu tiang pokok ajaran Islam. Zakat mengandung tujuan yaitu sasaran praktisnya. Adapun Tujuan zakat dilihat dari kepentingan kehidupan sosial, antara lain bahwa zakat bernilai ekonomik, merealisasi fungsi harta sebagai alat perjuangan menegakkan agama Allah dan mewujudkan keadilan sosial ekonomi masyarakat pada umumnya.

Adapun tujuan dari zakat antara lain ialah :

1) Membantu, mengurangi dan mengangkat kaum fakir miskin dari kesulitan hidup dan penderitaan mereka. Dengan zakat tersebut fakir miskin mendapat keringanan untuk memenuhi sebagian dari kebutuhannya.

2) Membantu memecahkan permasalahan yang dihadapi oleh para Mustahikul Zakat, dalam permasalahan ekonomi, yang sedikit banyak membantu kebutuhan kehidupan mereka walaupun hanya sesaat.

3) Membina dan merentangkan tali solidaritas (persaudaraan) sesama umat manusia. Dengan menyisihkan harta kekayaan tersebut rasa persaudaraan akan menjadi kokoh.

4) Menghilangkan sifat bakhil dan loba pemilik kekayaan dan penguasa modal. Zakat yang dikeluarkan orang muslim hanya semata menurut perintah Allah dan mencari Ridhanya, akan mensucikannya dari segala kotoran dosa secara umum terutama kotornya sifat kikir.Sifat kikir yang tercela itu adalah tabiat manusia, yang dengannya manusia diuji, karenanya Allah swt sebagai rasa sayang-Nya kepada manusia. Firman Allah swt dalam alQur'an surat al-Isra' ayat 100:

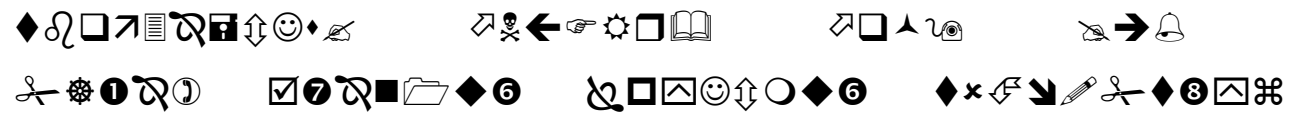




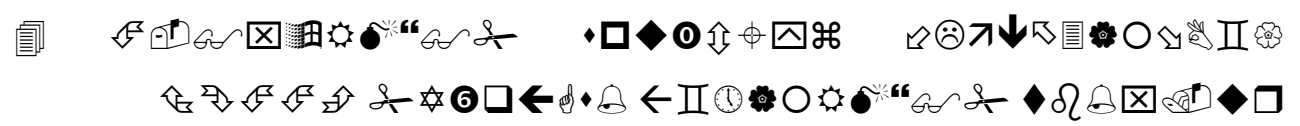

Artinya: Katakanlah Kalau seandainya kamu menguasai perbendaharaanperbendaharaan rahmat Tuhanku, niscaya perbendaharaan itu kamu tahan, karena takut membelanjakannya. Dan adalah manusia itu sangat kikir. ${ }^{129}$

5) Menghindarkan penumpukan kekayaan perseorangan yang di kumpulkan di atas penderitaan orang lain.

6) Mencegah jurang pemisah kaya miskin yang dapat menimbulkan mala petaka dan kesehatan sosial.

7) Mengembangkan tanggung jawab perseorangan terhadap kepentingan masyarakat, dan kepentingan umum. Pada hakekatnya harta adalah titipan dan amanat dari Allah yang berarti ia memiliki tanggung jawab untuk membelanjakan harta sesuai dengan ketentuan Allah dengan menunaikan zakat menunjukan pada diri seorang tersebut telah ada sikap mendidik dan tanggung jawab kaena harta yang ada harus diberikan kepada orang yang berhak menerimanya. Mendidik untuk melaksanakan disipilin dan loyalitas seorang untuk menjalankan kewajibannya dan menyerahkan hak orang lain. Seseorang akan merasa terdidik dalam melaksankan ibadah zakat karena dengan adanya kewajiban yang harus diserahkan kepada orang yang berhak.

8) Membersihkan dan menyucikan harta seseorang.

9) Memperkembangkan dan menambah sesuatu pada harta kekayaan seseorang. Karena berhubungan hak orang lain dan suatu harta, akan menyebabkan harta tersebut bercampur atau kotor, yang tidak bisa suci kecuali dengan mengeluarkannya.

${ }^{129}$ QS. Al-Isra'/ $17: 100$ 


\section{BAB VII}

\section{KONSEP DAN TATA CARA}

\section{SHALAT JUM'AH, SHALAT JAMA' DAN SHALAT QASHAR}

\section{Capaian Perkuliahan}

1. Mampu memahami makna dan aturan-aturan shalat

2. Mampu mempraktekkan secara tertib tentang shalat Jum'ah, shalat jama', serta shalat Qashar

3. Membiasakan melaksanakan shalat sebagaimana yang dituntunkan oleh Rasulullah saw

\section{A. Shalat Jum'at}

1. Pengertian shalat Jum'at

Jum'at artinya berkumpul, pergaulan, mingguan, persahabatan. Jadi, shalat jum'at berarti shalat yang dilakukan sekali seminggu sebagai media pergaulan dan persahabatan bagi kaum muslimin, sehingga menimbulkan rasa solidaritas sosial. ${ }^{130}$ Menurut Masyhud bahwa, shalat Jum'at adalah shalat dua rakaat yang didahului dengan khutbah, dilakukan dengan berjamaah, di waktu dhuhur pada hari Jum'at. Shalat ini hukumnya fardlu'ain, artinya bagi setiap muslim laki-laki mukallaf (dewasa), sehat (tidak sakit), bermukim (tidak bepergian) wajib melakukannya. ${ }^{131}$

Di dalam buku al-Islam Pendidikan Agama Islam juga menjelaskan, bahwa shalat yang wajib disamping shalat lima waktu adalah shalat Jum'at yang dilakukan setiap hari pada hari Jum'at pada waktu dhuhur dan dilakukan secara berjamaah dan diawali dengan dua khutbah. ${ }^{132}$ Ulama' telah sepakat bahwa shalat Jum'at termasuk fardu untuk setiap individu, ${ }^{133}$ yang berdasarkan firman Allah swt yaitu:

\footnotetext{
${ }^{130}$ Nafitri Imam Wahyudi. Sistematika Ajaran Islam. (Surabaya: Kanwil Depdikbud Jatim. 1997). 9.

${ }^{131}$ Masyhud, dkk. Pendidikan Al-Islamuntuk SMA/SMK/MA Muhammadiyah Kelas11. (Surabaya: Majelis Dikdasmen PWM Jatim. 2011). 53.

132 Rois Mahfud. Al-Islam Pendidikan Agama Islam. (Jakarta: Penerbit Erlangga. 2011). 26.

${ }^{133}$ Supiana dan Karman. Materi Pendidikan Agama Islam.(Bandung: PT Remaja Rosdakarya. 2004). 41.
} 


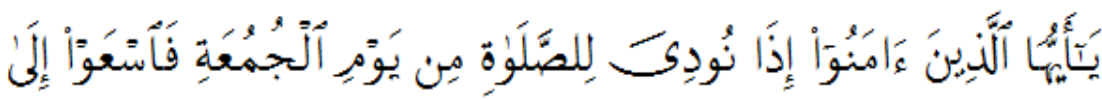

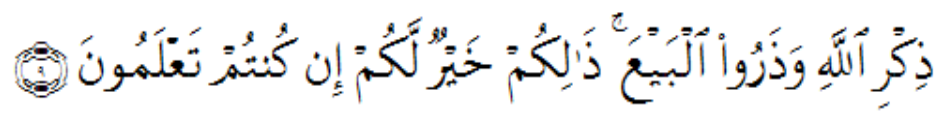

Hai orang-orang beriman, apabila diseru untuk menunaikan shalat Jum'at, Maka bersegeralah kamu kepada mengingat Allah dan tinggalkanlah jual beli. yang demikian itu lebih baik bagimu jika kamu mengetahui. ${ }^{134}$

Adapun sabda dari Rasulullah adalah sebagai berikut:

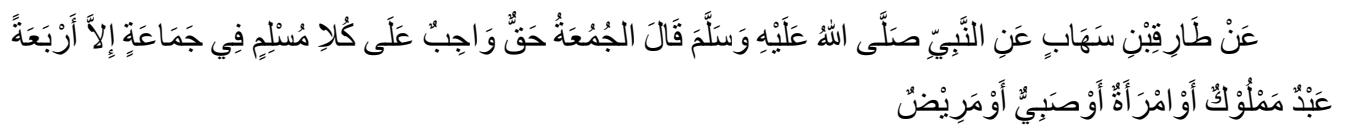

Dari Thariq ibnu Syihab, Rasulullah saw bersabda: Shalat Jum'at itu hak dan wajib dilakukan oleh setiap muslim dalam jamaah kecuali empat golongan, yaitu hamba (budak), perempuan, anak-anak, dan orang sakit. (H.R. Abu Daud no. 901)

Nabi bersabda:

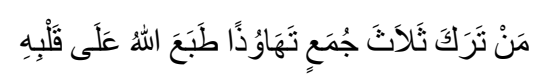

Barangsiapa yang meninggalkan shalat Jum'at 3 kali dengan merencanakan, sungguh Allah swt telah mencap (menutup) atas hatinya." (H.R. Abu Daud) ${ }^{136}$

Ada dari sebagian ulama yang berpendapat bahwa shalat Jum'at merupakan fardu kifayah. Bahkan Imam Malik menganggapnya sunat. Sebab perbedaan pendapat ini karena shalat Jum'at hampir sama dengan shalat Id. ${ }^{137}$

Shalat Jum'at dilakukan oleh setiap muslim, yang dilaksanakan secara berjamaah pada saat dhuhur di hari Jum'at. Shalat Jum'at diwajibkan bagi laki-laki yang sehat dan tidak dalam posisi bepergian, sedangkan shalat Jum'at tidak diwajibkan atas perempuan, budak, orang yang sakit dan musafir. Akan tetapi, tidak menutup kemungkinan perempuan boleh ikut asalkan tidak ada fitnah didalamnya.

\footnotetext{
134 Q.s al-Jumuah(62): 9.

135 Masyhud, dkk. Pendidikan Al-Islamuntuk SMA/SMK/MA Muhammadiyah Kelas11. (Surabaya: Majelis Dikdasmen PWM Jatim. 2011). 53.

${ }^{136}$ Kifayatul Akhyar. Terjemah Ringkas Fiqih Islam Lengkap. (Jakarta: Rineka Cipta. 1990). 68.

137 Supiana dan Karman. Materi Pendidikan Agama Islam.(Bandung: PT Remaja Rosdakarya. 2004). 41.
} 


\section{Ketentuan-Ketentuan Shalat Jum'at}

Dalam pelaksanaan shalat Jum'at ada beberapa ketentuan yang harus diperhatikan setiap muslim. Adapun ketentuan-ketentuannya sebagai berikut:

a. Syarat Wajib Shalat Jum'at

Shalat Jum'at dilaksanakan dengan syarat-syarat sebagai berikut: ${ }^{138}$

1) Islam.

2) Ballig (dewasa), anak-anak tidak diwajibkan.

3) Berakal, orang gila tidak wajib.

4) Laki-laki, perempuan tidak diwajibkan.

5) Sehat, orang yang sedang sakit atau berhalangan tidak diwajibkan.

6) Menetap (bermukim), orang yang sedang dalm perjalanan (musafir) tidak wajib.Hal ini dilandaskan pada sabda Nabi saw:

$$
\text { لاَجَجْعَةًا عَلَى مُسَافِرِ }
$$

Tidak ada kewajiban shalat Jum'at atas orang yang sedang bepergian. ${ }^{139}$

Sedangkan untuk orang-orang yang tidak diwajibkan untuk shalat Jum'at tetap dapat dan sah melakukan shalat Jum'at sebagai pengganti shalat dhuhur

b. Syarat Sah Mendirikan Shalat Jum'at

Dalam buku panduan Pendidikan Agama Islam dan Budi Pekerti kelas VII, Shalat Jum'at dianggap sah apabila memenuhi syarat sah sebagai berikut:

1) Dilaksanakan di tempat yang telah dijadikan tempat bermukim oleh penduduknya, baik di perkotaan maupun di pedesaan. Oleh karena itu, tidak sah mendirikan shalat Jum'at di ladang-ladang yang penduduknya hanya singgah disana untuk sementara waktu.

2) Dilakukan secara berjamaah. Tidak sah hukumnya tentang shalat Jum'at dilaksanakan sendiri-sendiri. Para ulama berbeda pendapat tentang jumlah orang untuk dapat mendirikan shalat Jum'at. Sebagian ulama mengatakan minimal 40 orang dan ada yang mengatakan minimal 2 orang.

3) Dilaksanakan pada waktu dhuhur. Hal ini sesuai dengan hadits Nabi Muhammad saw:

\footnotetext{
${ }^{138}$ Kementerian Pendidikan dan Kebudayaan. Pendidikan Agama Islam dan Budi Pekerti untuk SMP/MTs Kelas VII. Edisi Revisi. (Jakarta: Kementerian Pendidikan dan Kebudayaan. 2014). 126.

${ }^{139}$ Kifayatul Akhyar. Terjemah Ringkas Fiqih Islam Lengkap. (Jakarta: Rineka Cipta. 1990). 68.
} 


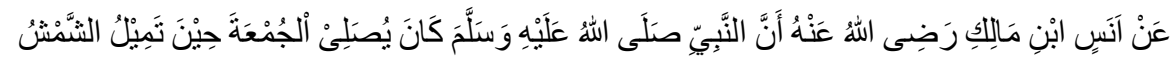

Dari Anas bin Malik, "sesungguhnya Rasulullah saw, shalat Jum'at ketika matahari telah tergelincir." (H.R. Bukhari)

4) Shalat Jum'at dilaksanakan dengan didahului dua khutbah.

Dalam buku lain menerangkan untuk sahnya pelaksanaan shalat Jum'at harus terpenuhi syarat-syaratnya, yaitu sebagai berikut: ${ }^{140}$

1) Diadakannya dilingkungan bangunan tempat tinggal orang-orang yang melakukan shalat Jum'at itu. Artinya, shalat Jum'at dilaksanakan di batas kota atau desa, seperti yang dilaksanakan pada masa Nabi Muhammad saw dan Khulafa alRasyidun.

Menurut Abu Hanifah, shalat Jum'at hanya dapat dilaksanakan di kota dan dengan izin penguasa, sedangkan Malik mengharuskan pelaksanaannya di Masjid. Perbedaan ini diakibatkan oleh pebedaan dalam memahami berbagai kondisi yang ada pada pelaksanaan shalat Jum'at dimasa Nabi. Sepanjang riwayat, beliau senantiasa melaksanakan shalat Jum'at dengan berjamaah di kota dan di Masjid Jami'.

2) Dilakukan dengan berjamaah, sebagaimana yang dilakukan Nabi dan Sahabat. Namun, ulama berbeda pendapat mengenai jumlah minimal bilangan jamaahnya. Menurut Abu Hanifah, minimal empat puluh orang ternasuk Imam. Malik tidak mengharuskan bilangan tertentu, namun jamaah Jum'at harus mencapai yang layak untuk membentuk perkampungan sendiri. Sedangkan menurut Ahmad dan Syafi'i jumlah mereka tidak kurang dari 40 orang, dan itu adalah bilangan jamaah Jum'at yang terkecil yang disebutkan dalam riwayat.

Sementara itu, menurut madhab Syafi'i, jamaah harus terdiri dari ahlu Jum'at, yakni merdeka, mukallaf, dan menetap di tempat pelaksanaan shalat tersebut. Mereka juga harus hadir dan mengikuti secara penuh dari awal khutbah hingga selesai shalat. Selain itu, disyaratkan pula shalat itu tidak didahului dan tidak serentak dengan shalat Jum'at lainnya di tempat itu. Menurut madhab Syafi'i ini, tidak dibenarkan mengadakan lebih dari satu shalat Jum'at di satu kota, kecuali benrbenar diperlukan.

3) Dilakukan sepenuhnya pada waktu shalat dhuhur, sesuai petunjuk Nabi Muhammad saw.

${ }^{140}$ Supiana dan Karman. Materi Pendidikan Agama Islam.(Bandung: PT Remaja Rosdakarya. 2004). $42-43$. 
4) Dua khutbah sebelum shalat. Keharusan khutbah ini diketahui dari hadits Jabir Ibn Samurah: "Rasul selalu berkhutbah dua kali pada hari Jum'at, duduk diantara keduanya, dan beliau berkhutbah dengan berdiri."

c. Rukun Jum'at

Rukun (fardhunya) Jum'at ada dua yaitu: ${ }^{141}$

1) Khutbah dua kali yang duduk di antara keduanya.

2) Shalat dua rakaat, dengan berjamaah.

Khutbah dikerjakan terlebih dahulu baru shalat 2 rakaat. Jabir bin Samurah meriwayatkan:

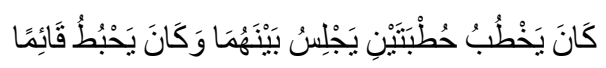

Adalah Nabi saw, berkhutbah 2 khutbah, duduk diantara keduanya, dan beliau berkhutbah dengan berdiri.

Dalam riwayat yang lain:

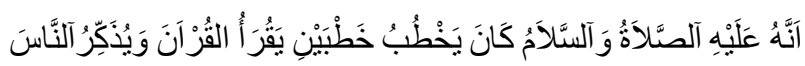

Bahwasannya Nabi saw, berkhurbah 2 khutbah, beliau membaca al-Qur'an dan memberi peringatan pada orang banyak. (H.R.Muslim)

d. Halangan Shalat Jum'at

Hal-hal yang dapat dijadikan alasan untuk boleh tidak shalat Jum'at adalah sebagai berikut: $^{142}$

1) Sakit, orang yang diperbolehkan tidak melaksanakan shalat Jum'at, tetapi harus melaksanakan shalat dzhuhur.

2) Hujan lebat, angin kencang, dan bencana alam yang menyulitkan untuk melaksanakan shalat Jum'at.

3) Musafir, yaitu orang yang sedang melaksanakan perjalanan jauh.

4) Perjalanan menuju tempat melaksanakan shalat Jum'at tidak aman.

Akan tetapi, tidak ada toleransi bagi orang muslim yang senantiasa meninggalkan shalat jum'at dengan berbagai alasan halangan. Dikatakan dalam sabda Nabi Muhammad saw:

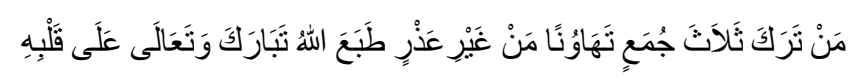

\footnotetext{
${ }^{141}$ Kifayatul Akhyar. Terjemah Ringkas Fiqih Islam Lengkap. (Jakarta: Rineka Cipta. 1990). 69.

${ }^{142}$ Kementerian Pendidikan dan Kebudayaan. Pendidikan Agama Islam dan Budi Pekerti untuk SMP/MTs Kelas VII. Edisi Revisi. (Jakarta: Kementerian Pendidikan dan Kebudayaan. 2014). 130.
} 
Barang siapa meninggalkan shalat Jum'at karena meremehkannya tanpa suatu alasan maka Allah Tabaroka wata'ala akan mengunci hatinya. (H.R. al-Bukhari dan Muslim) $)^{143}$

3. Persiapan Shalat Jum'at

Sebelum melaksanakan shalat Jum'at, ada beberapa hal yang perlu dipersiapkan terlebih dahulu, biasanya ini disebut dengan sunnah Jum'at. Antara lain:

a. Mandi seluruh tubuh, seperti mandi junub, meskipun tidak dalam keadaan junub. Rasulullah saw bersabda:

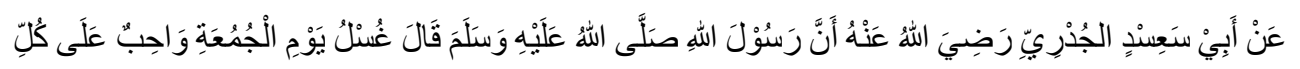

Dari Abu Said al-Hudri ra., Rasulullah saw bersabda: Mandi hari Jum'at itu wajib bagi setiap orang yang sudah baligh. (H.R. Bukhari, hadits ke 830)

b. Memakai pakaian yang baik, bersih dan harum. Sabda Rasulullah saw: ${ }^{144}$

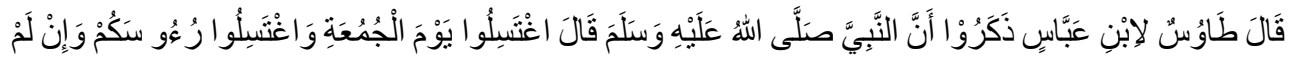

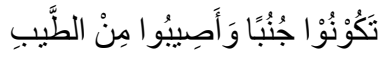

Thaus berkata kepada Ibnu Abbas mengingatkan bahwa Rasulullah saw bersabda:

Mandilah pada hari Jum'at, cucilah kepalamu meskipun kamu tidak junub, dan pakailah bau-bauan (harum). (H.R.Bukhari no. 835)

c. Memotong kuku, kumis, dan merapikan rambut.

d. Segera ke Masjid, memenuhi shaf pertama, dan tidak boleh melangkahi orang yang sedang shalat di depannya.

e. Banyak berdzikir dan berdoa kepada Allah swt.

4. Adab shalat Jum'at

a. Adab dalam masjid

Masjid merupakan tempat yang berbeda dengan tempat-tempat yang lainnya, masjid adalah rumah Allah (Baitullah). Bila memasuki masjid, ada beberapa hal yang harus diperhatikan, disamping itu hati harus khusyuk dan tenang: ${ }^{145}$

1) Saat masuk masjid, kaki kanan lebih dulu dimasukkan sambil berdoa. Kalau keluar, kaki kiri didahulukan sambil berdoa.

\footnotetext{
${ }^{143}$ Muhammad Faiz Almath. 1100 hadits terpilih: sinar ajaran Muhammad. (Jakarta: Gema Insani). 94.

${ }^{144}$ Masyhud, dkk. Pendidikan Al-Islamuntuk SMA/SMK/MA Muhammadiyah Kelas11. (Surabaya: Majelis Dikdasmen PWM Jatim. 2011). 54.

${ }^{145}$ Masyhud, dkk. Ibid. 54.
} 
2) Shalat tahiyatul masjid dua rakaat, meskipun khatib sedang berkhutbah. Ini berdasarkan sabda Nabi:

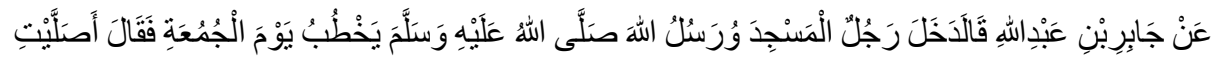

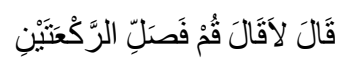

Jabir ibnu Abdullah berkata:"Seorang laki-laki masuk masjid, saat itu Nabi saw. Sedang khutbah Jum'at. Lalu Nabi saw bertanya kepadanya: Apakah kamu sudah shalat? Orang itu menjawab: Belum. Nabi menyuruh: Berdirilah dan shalatlah dua rakaat." (H.R.Bukhari no.879 dan Muslim no. 1445)

3) Setelah shalat tahiyatul masjid, duduk dengan tenang, khusyuk, banyak berdzikir dan berdoa, juga diperbolehkan shalat dua rakaat -dua rakaat sampai khutbah dimulai. Shalat ini disebut shalat intidhar (shalat menunggu datangnya imam dan khutbah dimulai)

b. Adab mengikuti khutbah

Terdapat beberapa hal yang harus diperhatikan apabila khutbah sudah dimulai, yaitu sebagai berikut:

1) Tidak boleh bercanda, bercakap-cakap, bermain dengan teman kanan dan kirinya. Dalam hal ini perbedaan pendapat diantara para ulama, bahwa berbicara ketika imam berkhutbah hukumnya haram dan ada yang menjelaskan bahwa berbicara ketika khutbah dimulai itu tidak haram, diam dikala itu sunnat. Kedua-duanya mempunyai dalil yang mendsarinya. Pendapat yang pertama merajuk pada hadits Nabi yaitu:

Rasulullah saw bersabda:

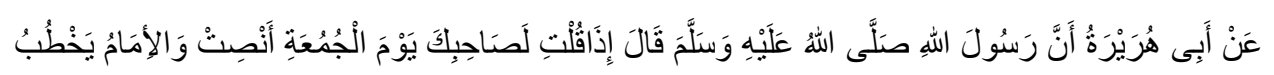

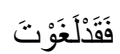

Dari Abu Hurairah, Rasulullah saw bersabda: Apabila kamu mengatakan kepada temanmu pada saat shalat Jum'at "diamlah" ketika khatib sedang berkhutbah, maka sungguh sia-sialah (shalat jum'atmu). (H.R. Bukhari no.882 dan Muslim no.1404).

Dalam riwayat lain menjelaskan:

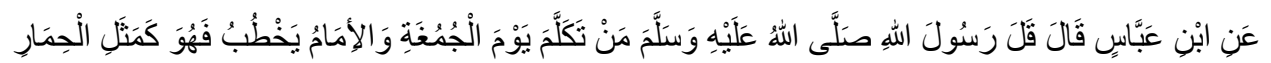

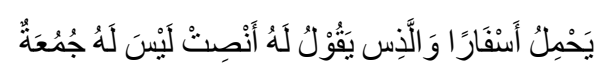

Artinya:

Dari Ibnu Abbas, Rasulullah saw bersabda: Siapa saja yang berbicara di saat shalat Jum'at ketika imam sedang berkhutbah, maka ia seperti keledai yang 
memikul kitab. Dan orang yang mengingatkan dengan mengatakan "diamlah" maka tidak ada (sia-sialah) shalat Jum'at baginya.(H.R. Ahmad no. 1929)

Hadits yang dijadikan sebagai rujukan bahwa berbicara ketika imam sedang berkhutbah itu tidak haram, dan diam yang diperintahkan itu termasuk sunnah, yaitu sebagai berikut:

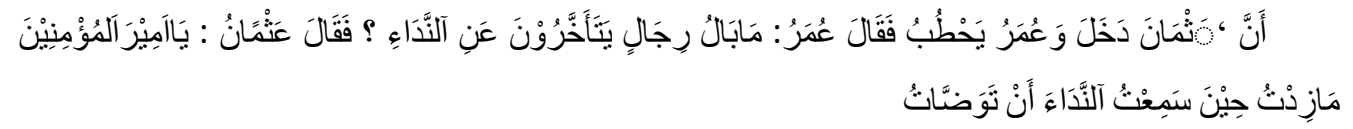

Bahwa Usman masuk dan Umar sedang berkhutbah, maka Umar berkata: Bagaimana halnya orang yang melambatkan panggilan? Usman berkata: Ya Amirul Mu'minin, sesungguhnya ketika terdengar adzan aku sedang wudhu, tidak lebih dari itu. (H.R. Bukhari dan Muslim)

Riwayat hadits menyebutkan yang artinya: Bahwa Nabi saw. Sedang khutbah pada hari Jum'at, seseorang datang seraya bertanya: "Waktu apakah ini? (Kapan waktunya?)" Orang banyak mengisyaratkan kepadanya agar diam, namun ia tidak berbuat. Oranng itu mengulangi pertanyaannya. Setelah yang kedua kali ini Rasulullah saw. Bersabda:"Celaka engkau. Apa yang engkau siapkan untuknya?" Orang itu menjawab: "Cinta kepada Allah dan Rasul-Nya." Nabipun bersabda: "Engkau bersama dengan yang engkau cintai."(H.R. Baihaqi) ${ }^{146}$

2) Memandang khatib sedang berkhutbah, serta memperhatikan pesan-pesan atau nasehat yang disampaikan. Rasulullah saw bersabda:

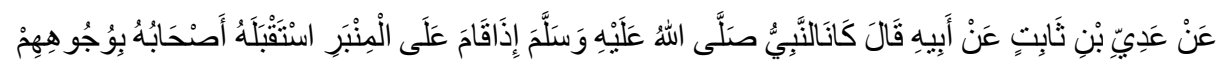

Adi ibnu Tsabit mendapatkan kisah dari bapaknya: ketika Nabi saw berdiri di mimbar (berkhutbah) maka para sahabatnya menghadapkan wajah mereka ke arah Nabi saw. (H.R. Ibnu Majah no. 1126)

3) Jangan bersandar di tiang atau dinding masjid untuk menuruti rasa mengantuk dan bermalas-malasan

5. Khutbah Jum'at

Khutbah Jum'at juga harus memenuhi beberapa ketentuan, yaitu:

a. Rukun Khutbah

\footnotetext{
${ }^{146}$ Kifayatul Akhyar. Terjemah Ringkas Fiqih Islam Lengkap. (Jakarta: Rineka Cipta. 1990). 72.

${ }^{147}$ Masyhud, dkk. Pendidikan Al-Islamuntuk SMA/SMK/MA Muhammadiyah Kelas11. (Surabaya: Majelis Dikdasmen PWM Jatim. 2011). 54.
} 
Rukun khutbah ada 5 perkara, yaitu: 1) Memuji kepada Allah dengan melafadhkan kata-kata pujian, 2) Membaca shalawat kepada Nabi Muhammad, 3) Berwasiat kepada hadirin untuk takwa, 4)Mendoakan kepada semua orang mukmin (baik yang sudah mati maupun yang masih hidup), 5) Membaca al-Qur'an (paling sedikit satu ayat). ${ }^{148}$

b. Syarat Khutbah

Syarat dalam berkhutbah ada 6 perkara, yaitu: 1) Sudah masuk waktunya (sudah mataharicondong ke barat), 2) Mendahulukan khutbah dari shalat, 3) Berdiri dari khutbah, 4) duduk di antara kedua khutbah, 5) Suci dari hadats dan najis pada pakaian, badan dan tempat, 6) Suaranya keras, sehingga terdengar oleh 40 orang. ${ }^{149}$

c. Sunnah Khutbah

1) Khutbah dilaksanakan di atas mimbar atas tempat yang tinggi.

2) Khutbah disampaikn dengan kalimah yng fasih, terang, dan mudah dipahami.

3) Khatib menghadap ke jamaah shalat Jum'at.

4) Khatib membaca salawat atau yang lainnya di antara dua khutbah.

5) Khatib menertibkan tiga rukun, yaitu dimulai dengan puji-pujian, salawat Nabi, dan berwasiat.

6) Jamaah shalat Jum'at hendaklah diam, tenang dan memperhatikan khotbah Jum'at.

7) Khatib hendaklah memberi salam.

8) Khatib hendaklah duduk di kursi mimbar sesudah memberi salam dan mendengarkan salam. ${ }^{150}$

d. Tata Cara Khutbah

Setelah masuk waktu dhuhur, khatib segera ke mimbar untuk menyampaikan khutbahnya, yang terdiri dari khutbah pertama dan khutbah kedua. Adapun isi khutbah sebagai berikut: ${ }^{151}$

1) Mengucapkan hamdallah, memuji bersyukur kepada Allah sebagai pemelihara alam semesta.

2) Membaca shalawat kepada Nabi Muhammad saw.

3) Membaca ayat-ayat al-Qur'an dan Hadits yang berkaitan dengan topik yang akan disampaikan.

\footnotetext{
${ }^{148}$ Kifayatul Akhyar. Terjemah Ringkas Fiqih Islam Lengkap. (Jakarta: Rineka Cipta. 1990). 69.

${ }^{149}$ Kifayatul Akhyar. Ibid. 70.

${ }^{150}$ Kementerian Pendidikan dan Kebudayaan. Pendidikan Agama Islam dan Budi Pekerti untuk SMP/MTs Kelas VII. Edisi Revisi. (Jakarta: Kementerian Pendidikan dan Kebudayaan. 2014). 128.

${ }^{151}$ Masyhud, dkk. Pendidikan Al-Islam untuk SMA/SMK/MA Muhammadiyah Kelas11. (Surabaya: Majelis

Dikdasmen PWM Jatim. 2011). 56
} 
4) Mengajak menambah ilmu dan taqwa kepada Allah swt, baik untuk diri sendiri maupun kepada hadirin (Jamaah shalat jum'at)

Setelah khutbah pertama selesai dilakukan, maka sang khatib duduk sebentar, lalu menyampaikan khutbah kedua. Rasulullah saw bersabada, yang artinya:

Jabir ibnu Sumarah berkata:Nabisaw berkhutbah dengan berdiri, kemudian duduk, lalu berdiri membac ayat-ayat al-qur'an dan mengingat Allah,dan khutbahnya sedang, shalatnya juga sedang.(H.R. Ibnu Majah no.1096)Dan Abdullah ibnu Umar berkata: Nabi sawkhutbah dua kali, dia duduk di antara dua khutbah tersebut. (H.R.Bukhari no.876)

Isi dari khutbah kedua hampir sama dengan isi dari khutbah pertama,dilanjutkan dengan memberi kesimpulan dari khutbah pertam. Terkadang bisa juga topiknya berbeda dengan khutbah pertama. Kemudian diteruskan dengan doa penutup. Dalamberkhutbah janganlah terlalupanjang sebab jamaah masih memiliki aktivitas lain yang harus dilaksanakan setelah shalat Jum'at. Khutbah yang baik adalah khutbah yang singkat dan padat, dilanjutkan dengan shalat berjamaah dua rakaat yang agak panjang. Sebagimana sabda Rasulullah saw:

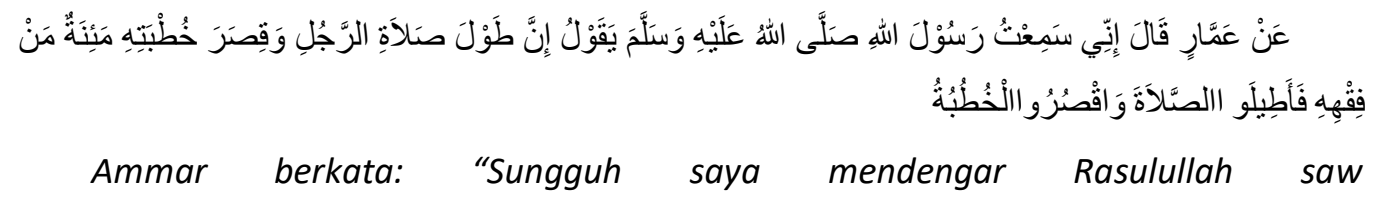
bersabda:Sesungguhnya panjang shalat Jum'at dan singkatnya khutbah menunjukkan kedalam pemahaman agamanya. Oleh karena itupanjangkanlah shalatmu dan pendekkanlah khutbahnmu." (H.R.Muslim. 1437)

\section{B. Shalat Jama' Qashar}

1. Pengertian

a. Jama'

Shalat Jama' adalah mengumpulkan shalat dhuhur dengan shalat ashar atau shalat maghrib dengan shalat isya'. ${ }^{152}$ Dalam buku lain menjelaskan shalat jama' artinya shalat fardu yang dikumpulkan atau digabungkan. Maksudnya shalat jama' menggabungkan dua shalat fardu dan mengerjakannya dalamsatu waktu saja. ${ }^{153}$

Dasar kebolehan dalam menjama'shalat dijelaskan dalam riwayat Mu'adz bin Jabal, ia berkata:

\footnotetext{
${ }^{152}$ Rois Mahfud. Al-Islam Pendidikan Agama Islam. (Jakarta: Penerbit Erlangga. 2011). 26

${ }^{153}$ Kementerian Pendidikan dan Kebudayaan. Pendidikan Agama Islam dan Budi Pekerti untuk SMP/MTs Kelas VII. Edisi Revisi. (Jakarta: Kementerian Pendidikan dan Kebudayaan. 2014). 140.
} 


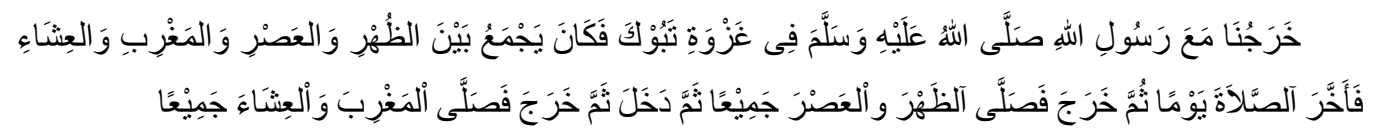

Kita pergi berperang Tabuk bersama Rasulullah saw, beliau menjama' antara shalat dhuhur dengan shalat ashar dan antara shalat maghrib dengan shalat isya'. Pada suatu hari beliau mengakhirkan shalat kemudian keluar pada shalat dhuhur dan ashar. Beliau masuk kemudian keluar lalu shalat maghrib dan Isya'.(H.R. Muslim) ${ }^{154}$

Dalam buku lain menjelaskan dalil yang digunakan sebagai dasar untuk menjama'shalat.

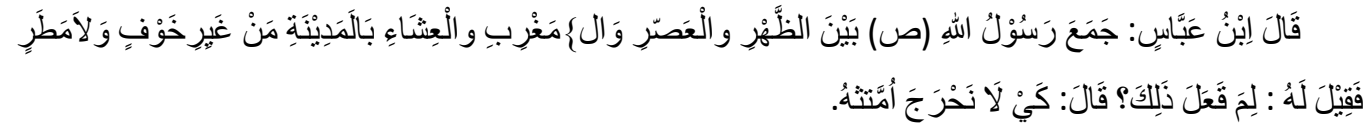

Ibnu Abbas Ra, berkata: Rsulullah saw, pernah menjama' shalat dhuhur dengan ashar dan maghrib dengan isya'di Madinah tanpa disebabkan faktor ketakutan (khauf) atau hujan. Beliau ditanya apa sebabnya, lalu menjawab, "agar tidak menyulitkan umatnya." (H.R. Muslim) ${ }^{155}$

Shalat Jama' terbagi menjadi 2 macam, yaitu Jama' Taqdim dan Jama' Ta'khir. Apabila shalat dhuhur dengan shalat ashar disatukan dengan shalat dhuhur dan dilakukan pada waktu dhuhur, atau shalat isya' disatukan dengan shalat maghrib dan dilakukan pada waktu maghrib, maka shalat yang disatukan itu disebut dengan shalat jama' taqdim. ${ }^{156}$ Sedangkan shalat yang dilakukan dengan sebaliknya yaitu shalat dhuhur dilakukan pada waktu ashar, atau shalat maghrib dilakukan pada waktu isya' maka shalat-shalat disebut dengan shalat jama' ta'khir.

Selain musafir, orang muqim juga dibenarkan melakukan shalat dengan jama' taqdim dengan alasan hujan, salju dan semacamnya. Dalam sebuah hadits menjelaskan: Nabi melakukan salat di Madinah delapan rakaat dengan jama' dan tujuh dengan jama': dzuhur dengan asar dan maghrib dengan isya'. (H.R. Bukhari dan Muslim). Dalam riwayat Muslim ditambahkan: bukan karena keadaan takut dan tidak pula safar. ${ }^{157}$

b. Qashar

\footnotetext{
${ }^{154}$ Kifayatul Akhyar. Terjemah Ringkas Fiqih Islam Lengkap. (Jakarta: Rineka Cipta. 1990). 66.

${ }^{155}$ Muhammad Faiz Almath. 1100 hadits terpilih: sinar ajaran Muhammad. (Jakarta: Gema Insani). 88.

${ }^{156}$ Rois Mahfud. Al-Islam Pendidikan Agama Islam. (Jakarta: Penerbit Erlangga. 2011). 26.

${ }^{157}$ Supiana dan Karman. Materi Pendidikan Agama Islam.(Bandung: Remaja Rosdakarya. 2004). 44
} 
Shalat qashar adalah meringkas shalat yang empat rakaat menjadi dua rakaat, yaitu shalat dhuhur, ashar dan isya'. Shalat ini sekaligus dengan meng-qashar-nya sehingga shalat-shalat yang empat rakaat diringkas menjadi dua-dua rakaat. ${ }^{158}$ Dalam buku karangan Supiana dan Karman menerangkan qashar artinya memendekkan pelaksanaan shalat yang semestinya empat rakaat menjadi dua rakaat. ${ }^{159}$

Shalat fardu yang bisa di qashar hanya tiga waktu saja, yaitu shalat yang raka'atnya 4. Sedangkan shalat yang tidak bisa di qashar yaitu shalat maghrib dan shalat subuh. Hukum dari shalat qashar adalah sunah sebagaimana yang telah dijelaskan dalam alQur'an. Allah berfirman dalam al-Qur'an surat al-Nisa ayat 101:

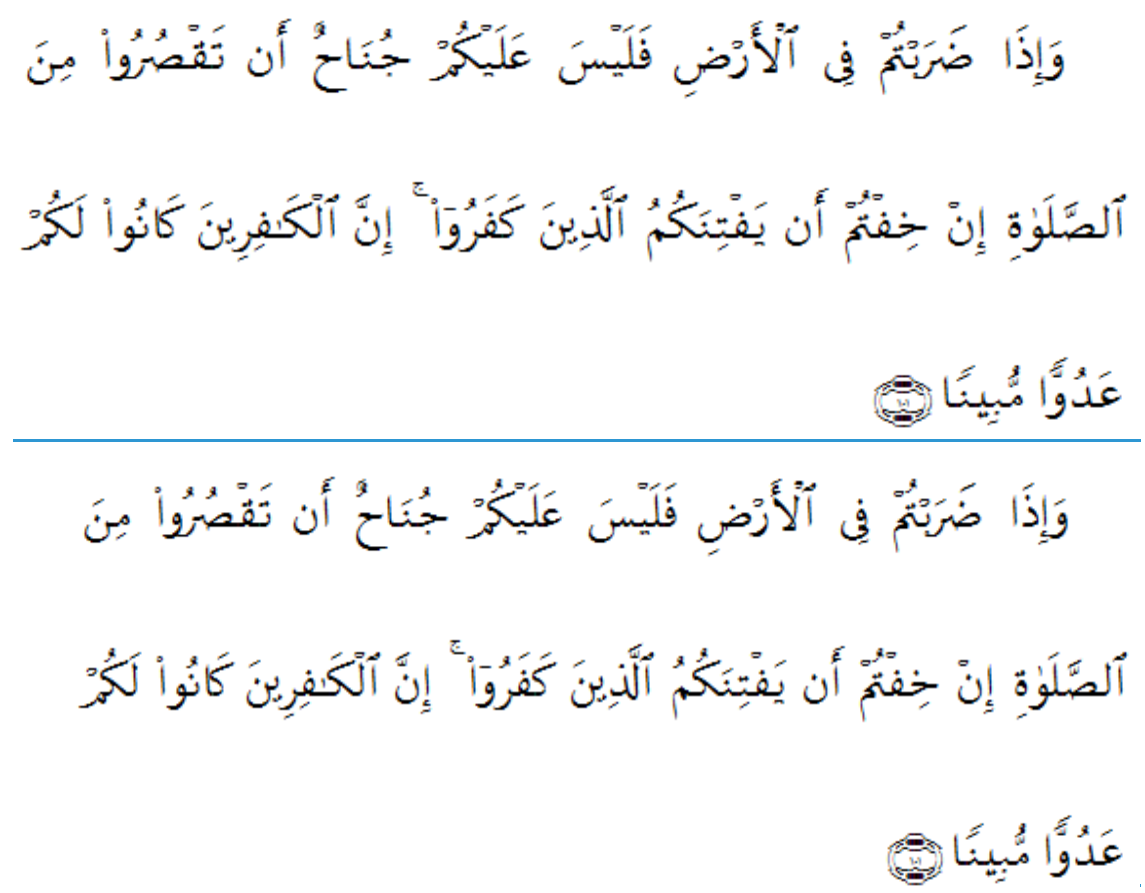

Artinya: Dan apabila kamu bepergian di muka bumi, maka tidaklah mengapa kamu mengqshar shalatmu, jika kamu takut diserang oleh orang-orang kafir. Sesungguhnya orang-orang kafir itu adalah musuh yang nyata bagimu. ${ }^{160}$

Ayat diatas menerangkan keringan untuk mengqashar shalat dengan keadaan takut terhadap gangguan orang kafir. Namun, Rasulullah saw menjelaskan bahwa ketentuan itu berlaku secara umum kendati tidak dalam waktu keadaan takut. Rasulullah saw menyebut bahwa qashar sebagai sadaqah dari Allah swt.

\footnotetext{
${ }^{158}$ Rois Mahfud. Al-Islam Pendidikan Agama Islam. (Jakarta: Penerbit Erlangga. 2011). 26

${ }^{159}$ Supiana dan Karman. Materi Pendidikan Agama Islam.(Bandung: PT Remaja Rosdakarya. 2004). 45.

${ }^{160}$ Depag RI, al-Qur'an dan Terjamah
} 


\section{Ketentuan-ketentuan shalat jama'}

a. Syarat melakukan shalat jama'

Syarat untuk melakukan shalat jama' sebagai berikut: ${ }^{161}$

1) Pada saat sedang melakukan perjalanan jauh, jarak tempuhnya tidak kurang dari $80,640 \mathrm{~km}$.

2) perjalanan yang dilakukan bertujuan baik, bukan untuk kejahatan dan maksiat.

3) Sakit atau dalam kesulitan.

4) Shalat yang dijama' shalat adaan (tunai) bukan shalat qadha'.

5) Berniat menjama' ketika takbiratul ikram.

Dan untuk pelaksanaan shalat dengan cara jama' taqdim harus memenuhi syarat sebagai berikut:

1) Tertib, yaitu melakukan kedua shalat itu sesuai dengan urutan waktunya, mendahulukan dhuhur atas ashar dan maghrib atas isya'.

2) Niat jama' ketika takbiratul al-ihram shalat pertama, atau setidak-tidaknya sebelum selesai shalat tersebut.

3) Wala', artinya pelaksanaan secara berurutan. shalat kedua tidak berselang lama dengan shalat pertama, sebab shalat kedua merupakan turutan bagi yang pertama.

4) Keadaan sebagai musafir masih berlanjut ketika ia memenuhi shalat kedua.

Dan untuk pelaksanaan shalat dengan cara jama' takhir, syaratnya yaitu:

1) Berniat, pada waktu shalat pertama, akan menjama' shalat tersebut dengan shalat kedua.

2) Pelaksanaan kedua shalat itu dalam keadaan musafir. bila safarnya putus sebelum shalat itu selesai dilaksanakan maka shalat pertama menjadi shalat qadha. ${ }^{162}$ Menjama' shalat bagi orang yang tidak bepergian bisa dilakukan dengan syarat: ${ }^{163}$

1) Hujan lebat diwaktu pertama, maksudnya waktu shalat dhuhur atau maghrib.

2) Dikerjakan di masjid, maksudnya saat hujan ia sudah berada di masjid.

\footnotetext{
${ }^{161}$ Kementerian Pendidikan dan Kebudayaan. Pendidikan Agama Islam dan Budi Pekerti untuk SMP/MTs Kelas VII. Edisi Revisi. (Jakarta: Kementerian Pendidikan dan Kebudayaan. 2014). 141.

162 Supiana dan Karman. Materi Pendidikan Agama Islam.(Bandung: PT Remaja Rosdakarya. 2004). 44.

163 Kifayatul Akhyar. Terjemah Ringkas Fiqih Islam Lengkap. (Jakarta: Rineka Cipta. 1990). 66-67.
} 


\section{b. Syarat melakukan shalat qashar}

Shalat qashar bisa dilakukan dengan memenuhi syarat sebagai berikut: ${ }^{164}$

1) Safar itu bukan dalam perjalanan maksiat. Maksudnya, qashar hanya dapat dilakukan bagi musafir yang dibenarkan oleh syariat, meliputi: safar wajib seperti safar haji, umrah, jihad; sfar mandub seperti menziarahi makam Nabi; safar mubah seperti perjalanan niaga dan sebagainya. Inilah pendapat yang dikemukakan oleh Abu Hanifah dan para pengikutnya. Sufyan Al-Tsauri dan Abu Tsaur.

2) Jarak yang ditempuh di dalam perjalanan itu mencapai 16 farsakh $=48$ mil Hasyimi $=4$ barid $=2$ marhalah = perjalanan dua hari $=89 \mathrm{~km}$. Mengenai jarak safar ini, Abu Hanifah berpendapat 3 marhalah, sedangkan mazhab Zhahiri mengatakan jarak perjalanan tidak dibatasi; qashar dapat dilakukan pada setiap perjalanan, jauh atau dekat.

3) Perjalanan itu dilakukan menuju ke suatu tempat tertentu. Artinya, orang yang bepergian tanpa tujuan, sekalipun jarak yang ditempuhnya jauh, tidak dibenarkan mengqashar salat.

4) Berniat qashar pada saat takbiratul ihram.

5) Tidak berimam kepada orang yang melakukan shalat dengan sempurna, baik imam itu muqim maupun musafir, tetapi tidak mengqashar shalatnya.

6) Shalat itu dilakukan setelah si musafir melampaui batas kota atau desa yang menjadi awal safarnya.

7) Shalat tersebut dilakukan sepenuhnya dalam keadaan musafir. Bila safarnya putus, misalnya ditengah pelaksanaan shalat itu ia sampai ke tujuan, maka ia harus menyempurnakannya menjadi empat rakaat.

8) Mengetahui bahwa ia boleh mengqashar shalat tersebut.

\section{Tata cara shalat jama' 165}

1) Shalat Jama' taqdim

Cara melaksanakan shalat jama' taqdim Dhuhur dengan Ashar, adalah sebagai berikut:

a) Mulailah memenuhi persyaratan untuk melaksanakan shalat.

b) Bersiap untuk melaksanakan shalat yang didahului dengan iqamah.

\footnotetext{
${ }^{164}$ Supiana dan Karman. Materi Pendidikan Agama Islam.(Bandung: PT Remaja Rosdakarya. 2004). 45-46.

165 Kementerian Pendidikan dan Kebudayaan. Pendidikan Agama Islam dan Budi Pekerti untuk SMP/MTs Kelas VII. Edisi Revisi. (Jakarta: Kementerian Pendidikan dan Kebudayaan. 2014). 143-148.
} 
c) Melaksanakan shalat dhuhur empat rakaat diawali dengan niat buntuk shalat jama' taqdim pada waktu takbiratul ikram.

d) Setelah niat, lanjutkan shalat dhuhur empat rakaat seperti biasa sampai salam.

e) Setelah salam langsung berdiri untuk melaksanakan shalat Asar empat rakaat yang didahului dengan niat shalat jama' taqdim.

f) selanjutnya melaksanakan shalat ashar empat rakaat seperti biasa sampai salam.

Shalat jama' taqdim Maghrib dengan Isya' sama seperti shalat jama' taqdim dhuhur dengan ashar.

2) Shalat Jama' takhir

Cara mekasanakan shalat jama' takhir hampir sama dengan jama' taqdim, akan tetapi tidak ada anjuran untuk melaksanakan yang mana yang didahulukan dhuhur atau ashar, maupun maghrib atau isya'.

3) Shalat Jama' Taqdim diqashar

Cara melaksanakan shalat jama' taqdim di qashar Maghrib dengan Isya' adalah:

a) Memenuhi persyaratan untuk melaksanakan shalat.

b) Melaksanakan shalat yang didahului dengan iqamah.

c) Melaksanakan shalat maghriub tiga rakaat yang diawali dengan niat untuk shalat jamak taqdim dan diqashar.

d) Melaksanakan shalat maghrib tiga rakaat sampai selesai.

e) Melaksanakan shalat isya' dua rakaat, yang didahului dengan iqamah dengan niat shalat jama' taqdim dan diqasar.

f) Melaksanakan shalat isya dua rakaat sampai selesai.

4) Shalat Jama' Takhir diqashar

Cara melaksanakan shalat jama' takhir di qashar, tata caranya hampir sama dengan jama' taqdim dan di qashar, hanya saja niatnya yang berbeda. 


\section{DAFTAR PUSTAKA}

Al-Faruqi, Ismail Raji'. Islam dan Kebudayaan. Bandung: Mizan, 1984.

Ali, Mohammad Daud. Pendidikan Agama Islam. Jakarta: PT Raja Grafindo Persada, 2013.

Bawani, Imam dan Isa Anshori, Cendekiawan Muslim Dalam Perspektif Pendidikan Islam. Surabaya: PT. Bina Ilmu, 1991.

Hasan, Muhammad Tholhah. Islam dan Masalah Sumber Daya Manusia. Jakarta: Lantabora Press, 2003.

Jalaluddin. Teologi Pendidikan. Jakarta: PT Raja Grafindo Persada, 2003.

Langgulung, Hasan. Pendidikan dan Peradaban Islam. Jakarta: Pustaka Al-Husna, 1985.

Nata, Abbudin. Filsafat Pendidikan Islam. Ciputat: Logos Wacana Ilmu, 1997.

Purwanto, Edi dan Suyadi. Pendidikan Agama Islam. Surakarta: Widya Duta, 2004.

Ramayulis. Ilmu Pendidikan Is/am. Jakarta: Kalam Mulia, 2008.

Sapuri, Rafy. Psikologi Islam: Tuntunan Jiwa Modern. Jakarta: PT Raja Grafindo Persada, 2009.

Shariati, Ali. Tugas Cendekiawan Muslim. Jakarta: PT. Raja Grafindo Persada, 1996.

Nata, Abuddin. 2010. Akhlak Tasawuf. Jakarta: Rajawali Pers.

Supiana dan Karman. Materi Pendidikan Agama Islam. Bandung: PT Remaja Roda Karya.

Husni Thoyar. 2004. Pendidikan Agama Islam. Jakarta: Pusat Kurikulum dan Pembukuan,

Muhammad Ali Somali, 2014. Etika Modern. Jakarta: PT Nur Al-Huda,

https://rohissmpsn14depok.wordpress.com

http://asysyariah.com/keutamaan-iffah-dan-bersabar.html

Al-Khaubawi, Usman bin Hasan bin Ahmad Syakir, Durratun Nashihiin. Beirut: Darul Kitab Al-Islamiy, 1949.

Al-Qur'anul Karim.

Umary, Barmawi. Materi Akhlak. Solo: CV. Ramadhani. 1967.

Supiana. M. Karman. Materi Pendidikan Agama Islam. (Bandung: PT Remaja Rosdakarya. 2004. 
Kementerian Pendidikan dan Kebudayaan. Pendidikan Agama Islam dan Budi Pekerti. Edisi revisi. Jakarta: Kementerian Pendidikan dan Kebudayaan. 2014.

Moh Rathomy, Abdai. Sendi Agama Tauhid Fiqih Tasawuf. Tiga Serangkai. 1983.

Bagir, Muhammad Al-Habsyi, Fiqih praktis menurut Al-Quran,As-sunnah, dan pendapat para ulama. Bandung: Mizan. 1999.

M. Pustaka. Abatasa. Macam - macam ibadah. Pustaka. http//: m.pustaka.abatasa.co.id>detail>fiqih.macam-macam-ibadah.html. diakses pada rabu, 23 Maret 2016.

Zuhdi, Masjfuk. Studi Islam jilid II: Ibadah. Jakarta: CV. Rajawali. 1988.

Syaikh Abdur Razzaaq al-Abbaad. Sebab-Sebab Naik Turunya Iman. Jakarta: Cakrawala Publishing, 2004.

Mustahdi dan Sumiyati ,2014. Pendidikan Agama Islam dan Budi Pekerti kelas VII, Edisi Revisi. Jakarta : Kementerian Pendidikan dan Kebudayaan.

Rahmah, Syifalir. 2008. Malaikatpun ingin menjadi Manusia. Surabaya; Ikhtiar Surabaya.

Imam Abdirrahim Bin Ahmad Al-Qadhiy, 2003. Rahasia Alam Ghaib Dan Alam Akhirat (Terjemah Daqqoiqul Akhbar). Surabaya : Ampel Mulia.

Departemen Agama RI. 2005. Al-Qur'an dan Terjemahnya. Semarang: Karya Putra.

Hidayat Rachmat, Hendriyana Budi ,pendidikan agama Islamuntuk smp kela VII (Jakarta : Pusat Kurikulum dan Perbukuan, Kementerian Pendidikan Nasional, 2011).

Amin, Ahmad, Etika (Ilmu Akhlak), (Terj), Farid M'aruf, dari judul asli al-Akhlak, Jakarta:Bulang Bintang, 1983

Karim, Helmi. Fiqh Muamalah. Jakarta : PT.RajaGrafindo Persada, 2002.

Poerbakawatja, R. Soegarda . Ensiklopedi Islam. Jakarta: Ichtiar Baru Van Hoeve, 1999.

Dahlan, Abdul Aziz. Ensiklopedi Hukum Islam. Jakarta: Ichtiar Baru van Hoeve, 1996.

Muhammad. Zakat Profesi Wacana pemikiran dalam Fiqih Kontemporer. Jakarta: Salemba Diniyah, 2002.

Supiana, M. Kamal. Materi Pendidikan Agama Islam. Bandung : PT.Rosdakarya, 2004.

Ash Shiddieqy,T.M. Hasbi Pedoman Zakat, ( Jakarta : PT. Bulan Bintang , 1897.

Akhyar, Kifayatul. 1990. Terjemahan Ringkas Fiqh Islam Lengkap. Jakarta: Rineka Cipta

Almath, Muhammad Faiz. 1991. 1100 hadits terpilih: sinar ajaran Muhammad. Jakarta: Gema Insani.

Mahfud, Rois. 2011. Al-Islam Pendidikan Agama Islam. Jakarta: Penerbit Erlangga.

Supiana dan Kariman. 2004. Materi Pendidikan Agama Islam. Bandung: PT Remaja Rosdakarya. 
Nasution, Lahmuddin. 1995. Figh 1. Logos Wacana Ilmu dan Pemikiran.

Kementerian Pendidikan dan Kebudayaan. 2014. Pendidikan Agama Islam dan Budi Pekerti untuk SMP/MTs kelas VII. Edisi Revisi. Jakarta: Kementerian Pendidikan dan Kebudayaan.

Masyhud, dkk. 2011. Pendidikan Al-Islam untuk SMA/SMK/MA Muhammadiyah Kelas 11. Surabaya: Majelis Dikdasmen PWM Jatim.

Wahyudi, Nafitri Imam Wahyudi. 1997. Sistematika Ajaran Islam. Surabaya: Kanwil Depdikbud Jatim. 